\title{
AMERICAN PAINTINGS
}

\section{THE VERY NOTABLE COLLECTION}

FORMED BY

\section{Dr. Alexander C. Humphreys}

PRESIDENT OF STEVENS INSTITUTE

THE AMERICAN ART ASSOCIATION MADISON SQUARE SOUTH NEW YORK 

S.6.

IMETITUTION

3066. 

ON FREE PUBLIC VIEW

\section{AT THE AMERICAN ART GALLERIES}

MADISON SQUARE SOUTH, NEW YORK

BEGINNING FRIDAY, FEBRUARY 9th, 1917

FROM 9 A.M. UNTIL 6 P.M.

AND CONTINUING UNTIL NOON OF THE DATE OF SALE

(SUNDAY EXCEPTED)

THE VERY NOTABLE

DR. ALEXANDER C. HUMPHREYS

COLLECTION

TO BE SOLD AT UNRESTRICTED PUBLIC SALE

ON THE EVENINGS OF

WEDNESDAY AND THURSDAY, FEBRUARY 14th AND 15th

IN THE GRAND BALLROOM OF

\section{THE HOTEL PLAZA}

FIFTH AVENUE, 58th TO 59th STREET

BEGINNING EACH EVENING PROMPTLY AT 8.15 O'CLOCK 

ILLUSTRATED CATALOGUE

$\mathrm{OF}$

THE VERY NOTABLE COLLECTION

$\mathrm{OF}$

\section{AMERICAN PAINTINGS}

FORMED DURING THE PAST TWENTY-FIVE YEARS BY

Dr. Alexander C. Humphreys

PRESIDENT OF STEVENS INSTITUTE

THE ENTIRE COLLECTION TO BE SOLD

AT UNRESTRICTED PUBLIC SALE

ON THE EVENINGS HEREIN STATED

IN THE GRAND BALLROOM OF

\section{THE HOTEL PLAZA}

CATALOGUE WRITTEN BY WILLIAM A. COFFIN, N.A.

THE SALE WILL BE CONDUCTED BY

MR. THOMAS E. KIRBY

AND HIS ASSISTANT, MR. OTTO BERNET, OF THE

AMERICAN ART ASSOCIATION, MANAGERS

MADISON SQUARE SOUTH

NEW YORK 
THE AMERICAN ART ASSOCIATION

DESIGNS ITS CATALOGUES AND DIRECTS

ALL DETAILS OF ILLUSTRATION

TEXT AND TYPOGRAPHY 


\section{CONDITIONS OF SALE}

1. Any bid which is merely a nominal or fractional advance may be rejected by the auctioneer, if, in his judgment, such bid would be likely to affect the sale injuriously.

2. The highest bidder shall be the buyer, and if any dispute arise between two or more bidders, the auctioneer shall either decide the same or put up for re-sale the lot so in dispute.

3. Payment shall be made of all or such part of the purchase money as may be required, and the names and addresses of the purchasers shall be given immediately on the sale of every lot, in default of which the lot so purchased shall be immediately put up again and re-sold.

Payment of that part of the purchase money not made at the time of sale shall be made within ten days thereafter, in default of which the undersigned may either continue to hold the lots at the risk of the purchaser and take such action as may be necessary for the enforcement of the sale, or may at public or private sale, and without other than this notice, re-sell the lots for the benefit of such purchaser, and the deficiency (if any) arising from such re-sale shall be a charge against such purchaser.

4. Delivery of any purchase will be made only upon payment of the total amount due for all purchases at the sale.

Deliveries will be made on sales days between the hours of $\mathbf{9}$ A. M. and 1 P. M., and on other days-except holidays-between the hours of 9 A. M. and 5 P. M.

Delivery of any purchase will be made only at the American Art Galleries, or other place of sale, as the case may be, and only on presenting the bill of purchase.

Delivery may be made, at the discretion of the Association, of any purchase during the session of the sale at which it was sold.

5. Shipping, boxing or wrapping of purchases is a business in which the Association is in no wise engaged, and will not be performed 
by the Association for purchasers. The Association will, however, afford to purchasers every facility for employing at current and reasonable rates carriers and packers; doing so, however, without any assumption of responsibility on its part for the acts and charges of the parties engaged for such service.

6. Storage of any purchase shall be at the sole risk of the purchaser. Title passes upon the fall of the auctioneer's hammer, and thereafter, while the Association will exercise due caution in caring for and delivering such purchase, it will not hold itself responsible if such purchase be lost, stolen, damaged or destroyed.

Storage charges will be made upon all purchases not removed within ten days from the date of the sale thereof.

7. Guarantee is not made either by the owner or the Association of the correctness of the description, genuineness or authenticity of any lot, and no sale will be set aside on account of any incorrectness, error of cataloguing, or any imperfection not noted. Every lot is on public exhibition one or more days prior to its sale, after which it is sold "as is" and without recourse.

The Association exercises great care to catalogue every lot correctly, and will give consideration to the opinion of any trustworthy expert to the effect that any lot has been incorrectly catalogued, and, in its judgment, may either sell the lot as catalogued or make mention of the opinion of such expert, who thereby would become responsible for such damage as might result were his opinion without proper foundation.

AMERICAN ART ASSOCIATION, American Art Galleries, Madison Square South, New York City. 
CATALOGUE 


\section{FIRST EVENING'S SALE}

WEDNESDAY, FEBRUARY 14, 1917

\section{IN THE GRAND BALLROOM OF THE PLAZA}

Fifth Avenue, 58th to 59th Street

BEGINNING PROMPTLY AT 8.15 O'CLOCK

Nos. 1 to 83 , inclusive 
No. 1

\title{
HENRY MOSLER
}

\author{
American : 1841 -
}

\section{GOOD-NIGHT}

\section{Height, 12 inches; width, 9 inches}

Half-Length picture of a child in night-robe and cap, in full view to the spectator; the face lighted by a candle, the flame of which is shielded by the child's left hand.

Signed at the lower left, and dated PARIS, 1893.

No. 2

\section{FREDERICK BALLARD WILLIAMS, N.A.}

American : 1871-

\section{THE QUIET HOUR}

\section{Height, 12 inches; width, 91/4 inches}

A GROUP of three young women with gowns and draperies of white, yellow, blue and dark red. The one farthest away from the spectator is playing on a lute. Background of foliage and sky.

Signed at the lower right.

Purchased direct from the artist, $190 \%$. 


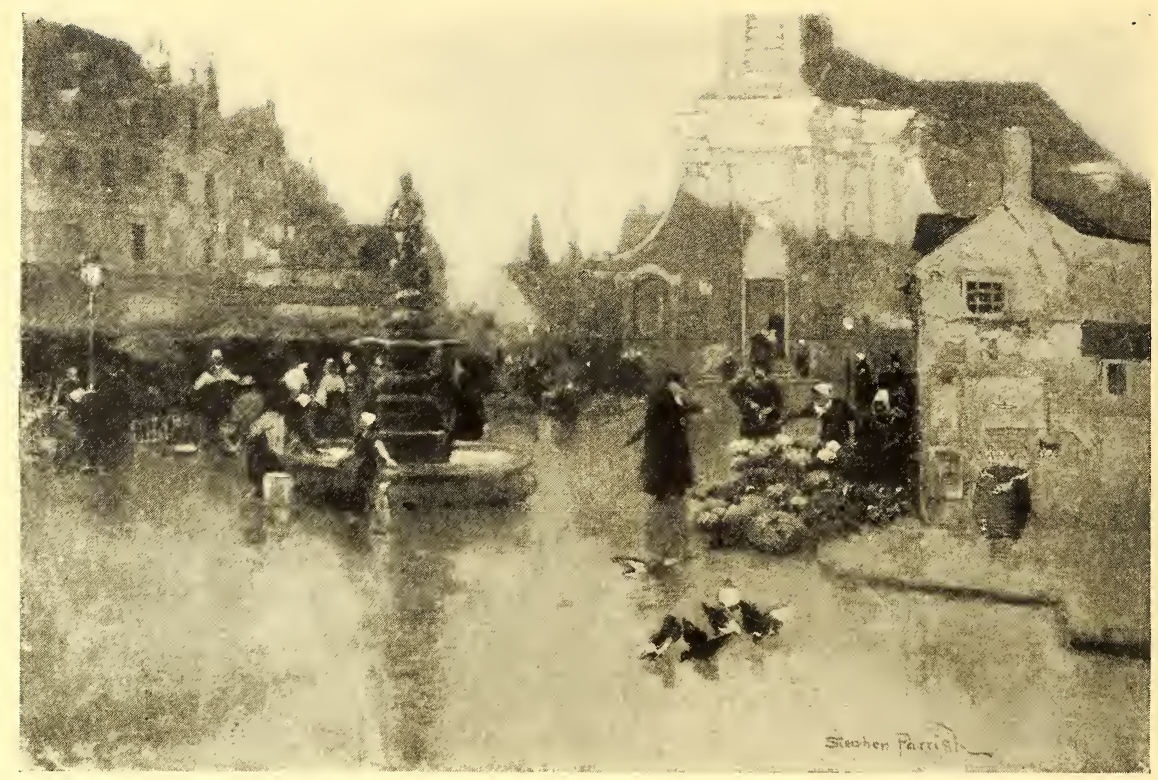

No. 3

\section{STEPHEN PARRISH}

American: 1846-

\section{MARKET-PLACE, YVETÔT, NORMANDY}

\section{Height, 9 inches; length, 123/4 inches}

THE market-place with a fountain, which appears in the left center of the picture, occupies the foreground and is bordered with buildings, including a church. The effect depicted is one of late afternoon, all the foreground and middle distance being in shadow, while sunlight illumines the upper part of the red walls of the church and catches here and there a bit of wall or a chimney. Numerous figures-buyers and vendors, a priest and others-animate the scene.

Signed at the lower right. 
No. 4

\section{RALPH ALBERT BLAKELOCK, N.A.}

Americhan: $18+\%$

SUMMER-CATSKILLS

Millboard: Height, 7 inches; width, $41 / 2$ inches

A LitTLE stream trickles over rocks in the center of the foreground, on the left a tree with its foliage stretching up near the top of the canvas, and on the right a mountainside. Beyond is seen a patch of bluish sky.

Signed at the lower right.

On back, inscribed in red: "Summer, Catskills, R. A. BlaKelock."

Frederick S. Gibbs Collection, New York, 1904, Catalogue No. 10.

No. 5

\section{CHILDE HASSAM, N.A.}

American: 1859-

\section{MESSENGER BOY}

\section{Height, 16 inches; width, 12 inches}

ONE of the artist's street scenes, which rank among the best of his works, showing the snow-covered sidewalks and roadway of a street in New York. Several cabs, a street piano, pulled along the roadway by a man and a woman, a man with a pushcart and a few pedestrians enliven the scene while, in the immediate foreground, at a corner, a messenger boy trudges along in pursuit of his errand.

Signed at the lower left, and dated 1901. 
No. 6

\title{
LOUIS LOEB, N.A.
}

\author{
Americhin : $1866-1909$
}

\section{BYBLIS}

Panel: Height, 16 inches; width, 10 inches

A seated figure of a young woman, in side view, nude to the hips and with draperies below of white and dark green. Leaning on a rock, her head is pillowed on her arm, and following the legend by which the nymph Byblis is said to have been changed into a spring, a little water is seen trickling over the rock. A representative example of the work of a talented artist, notable, among other qualities for its excellent drawing and atmospheric envelope as well as harmonious color.

Signed at the lower right, and dated 1903. 


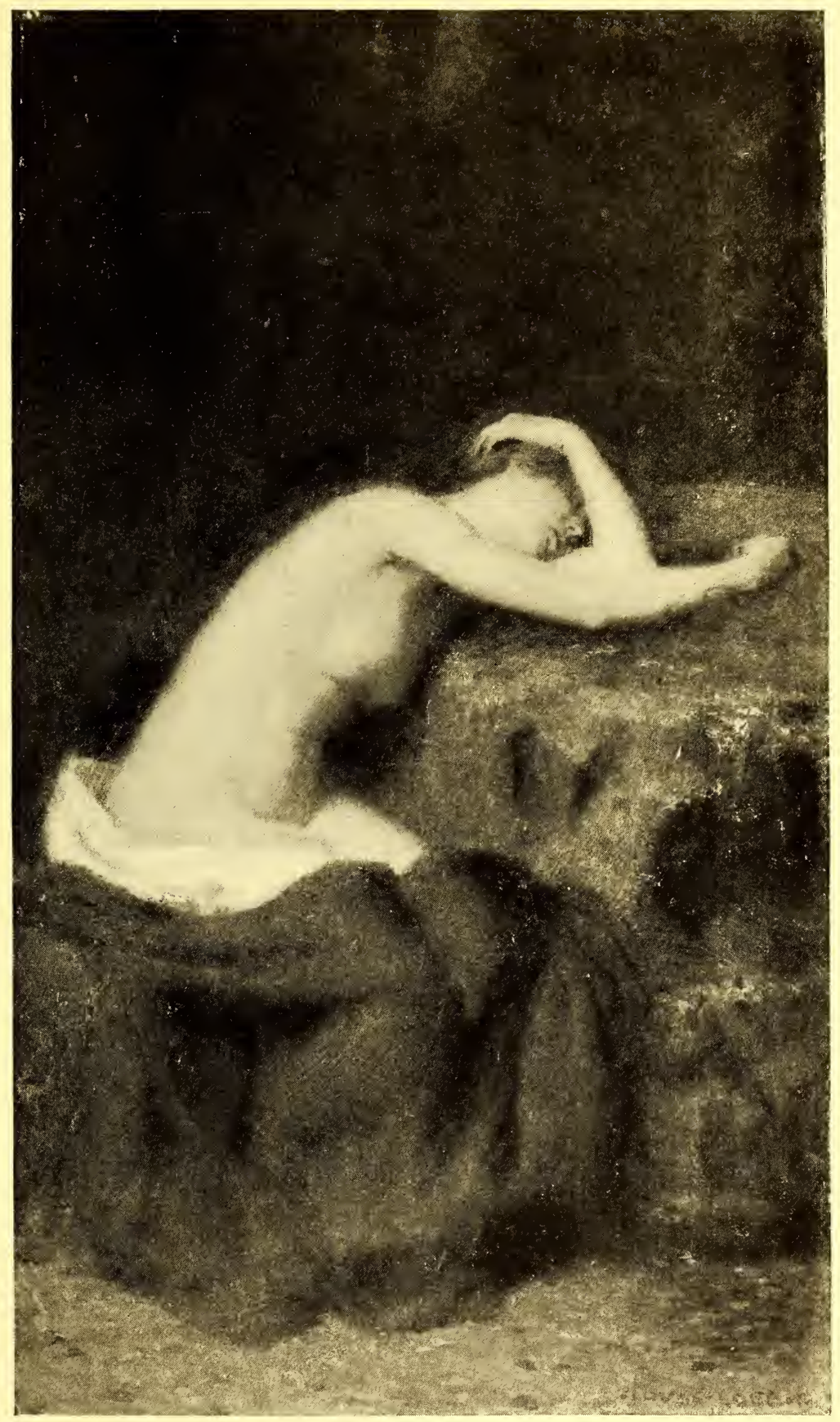


No. 7

\title{
BRUCE CRANE, N.A.
}

Anerican: 185\%-

\section{EVENING}

\author{
Height, 11 inches; length, 14 inches
}

'THE foreground consists of meadows and a pool; trees are spaced across the composition in the middle distance; a house appears amid the foliage on the left, and beyond is a range of hills. 'The evening sky shows, in its lower portion, a luminous effect of warm white, mingled with pale blue. In the upper portion are warmer tints, verging on orange, where clouds are floating.

Signed at the lower right. 


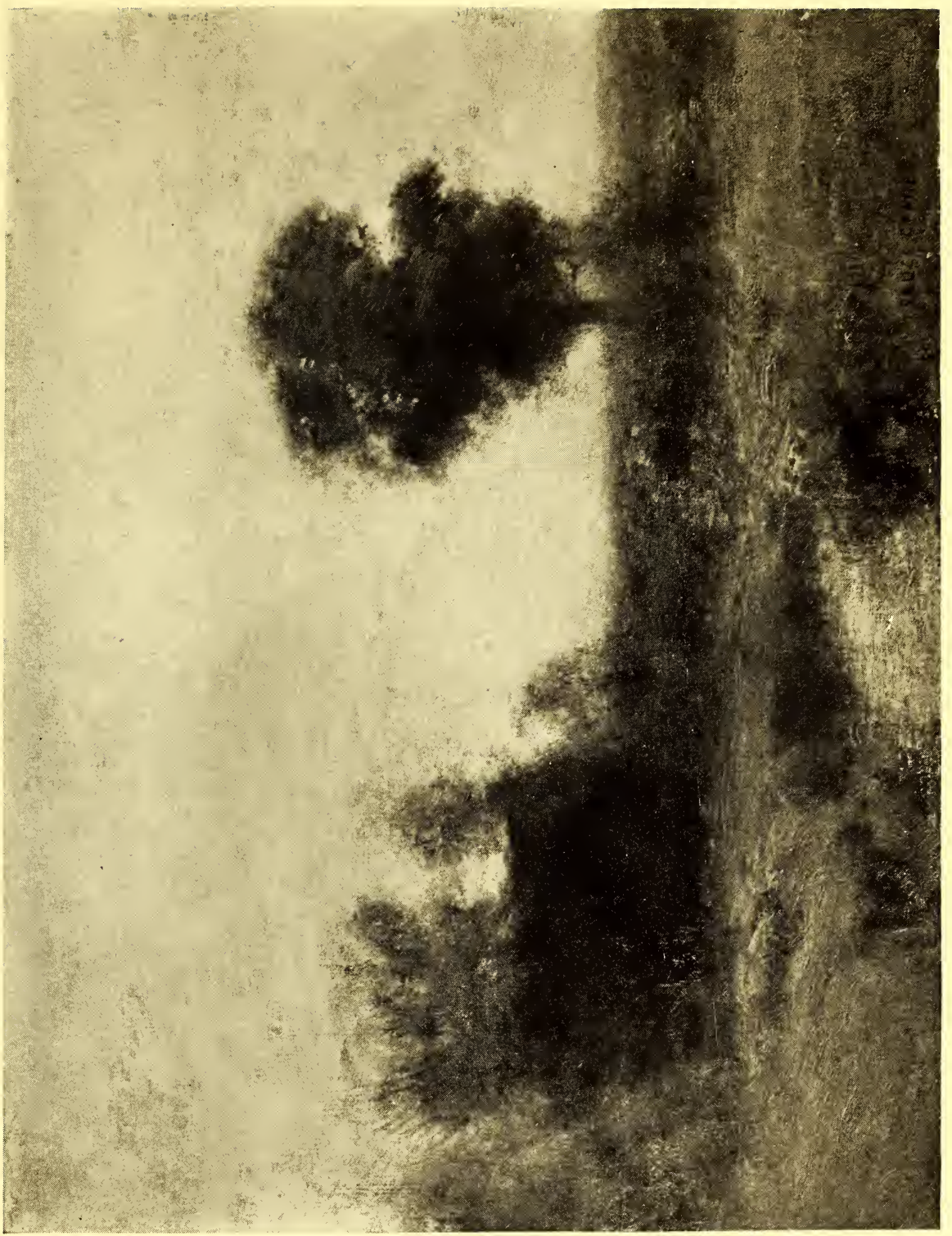


No. 8

\section{J. FRANCIS MURPHY, N.A.}

American : 1853-

\section{EARLY AUTUMN}

\section{Height, 10 inches; length, 14 inches}

A pleasing composition, including meadows and trees, a pond and a white cottage. The foliage of the trees, in part green and in part of russet hue, is soberly toned, and a gray sky with glimpses of blue accords with the other elements of the picture.

Signed at the lower left, and dated '05.

Frederick S. Gibbs Collection, New York, 1904, Catalogue No. 136. 


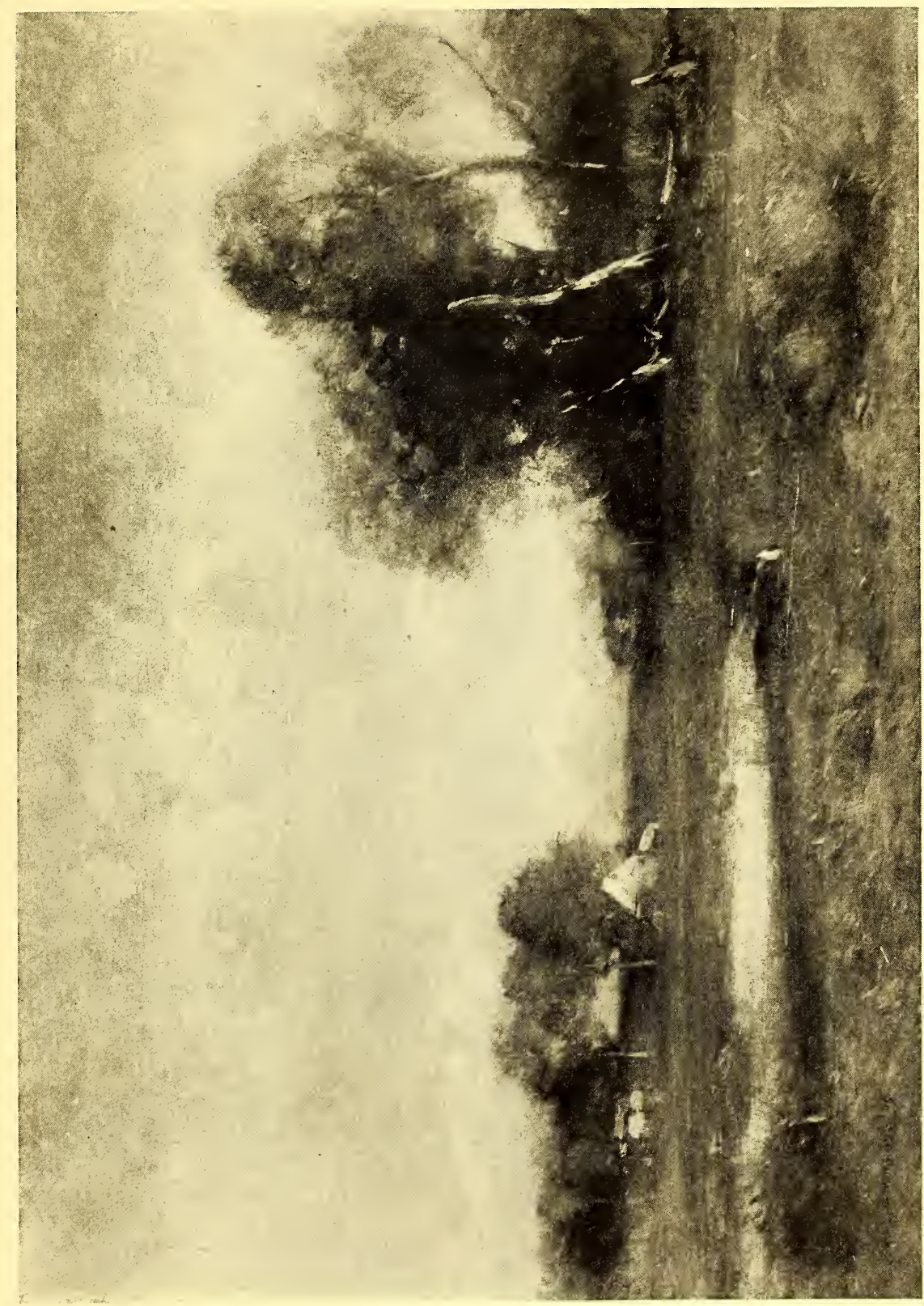




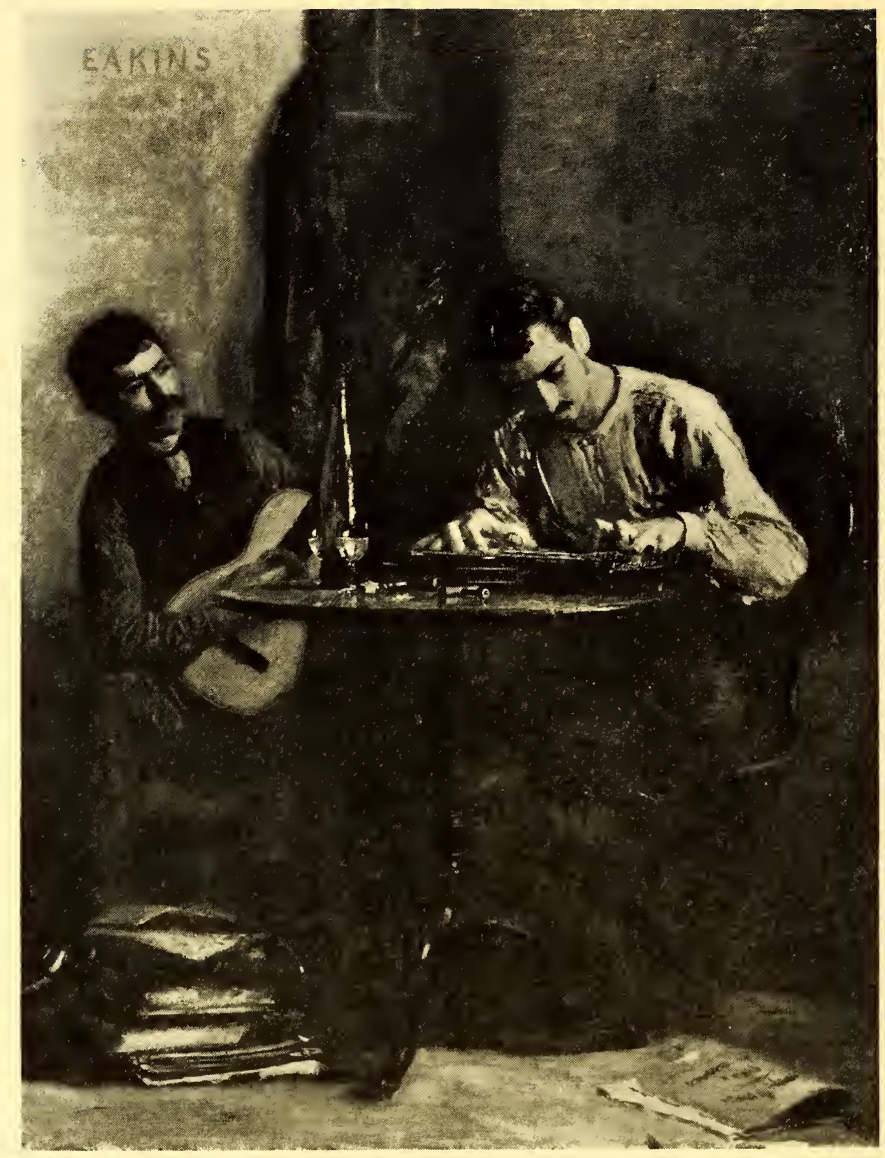

No. 9

THOMAS EAKINS, N.A.

American : $1844-1916$

\section{PROFESSIONALS AT REHEARSAL}

Height, 16 inches; width, 12 inches

ONe of the most celebrated of all of Eakins's genre pictures. It shows a group of two seated figures; one a man with white shirt, playing the zither which is on a table before him, and his companion on the left of the table, somewhat farther away, playing a guitar. 'The light is concentrated on the most prominent figure, lighting up the head, the hands and the shirt.

Signed at the upper left.

Thomas B. Clarke Collection, New Irork, 1899, Catalogue No. 342. 
No. 10

\section{HENRY GOLDEN DEARTH, N.A.}

American : $1864-$

\section{PASSING OF THE WAVE}

Panel: Height, 13 inches; length, 16 inches

A PICTURE of the sea, with rocks in the foreground, over which the water is tumbling and surging, breaking into white foam. Beyond lies the blue-green expanse of the ocean with breakers running in, crowned with white. At the top of the picture is a strip of gray sky. The color quality of this picture gives it a distinctive charm.

Signed at the lower left.

Purchased direct from the artist, New York, 1912.

No. 11

\section{CHILDE HASSAM, N.A.}

American : 1859

\section{ACROSS THE PARK}

Millboard: Height, 141/2 inches; length, 211/2 inches

A view of the upper part of New York, seen across Central Park. Slender trees, with some autumn foliage still clinging to their branches, and snow-covered roads with hansom cabs driving along, occupy the lower part of the picture. Beyond are the buildings and towers of the city, illumined by the last rays of the setting sun, and above is a space of evening sky with the full moon rising through the haze.

Signed at the lower left, and dated 1905.

Purchased from William Macbeth, New York, $190 \%$. 
No. 12

\section{HORATIO WALKER, N.A.}

American: 1858 -

\section{THE END OF THE DAY}

Water Color: Height, 12 inches; length, 17 inches

A Boy with a blue jacket is seen standing by the doorway of a stable, while a horse whose day's work is over is entering to rest for the night. This group, and the stable with its thatched roof, occupy the left half of the picture, and on the right is a view of green fields with the sun sinking below the horizon.

Signed at the lower left.

Purchased from William Macbeth, New York, 1904. 


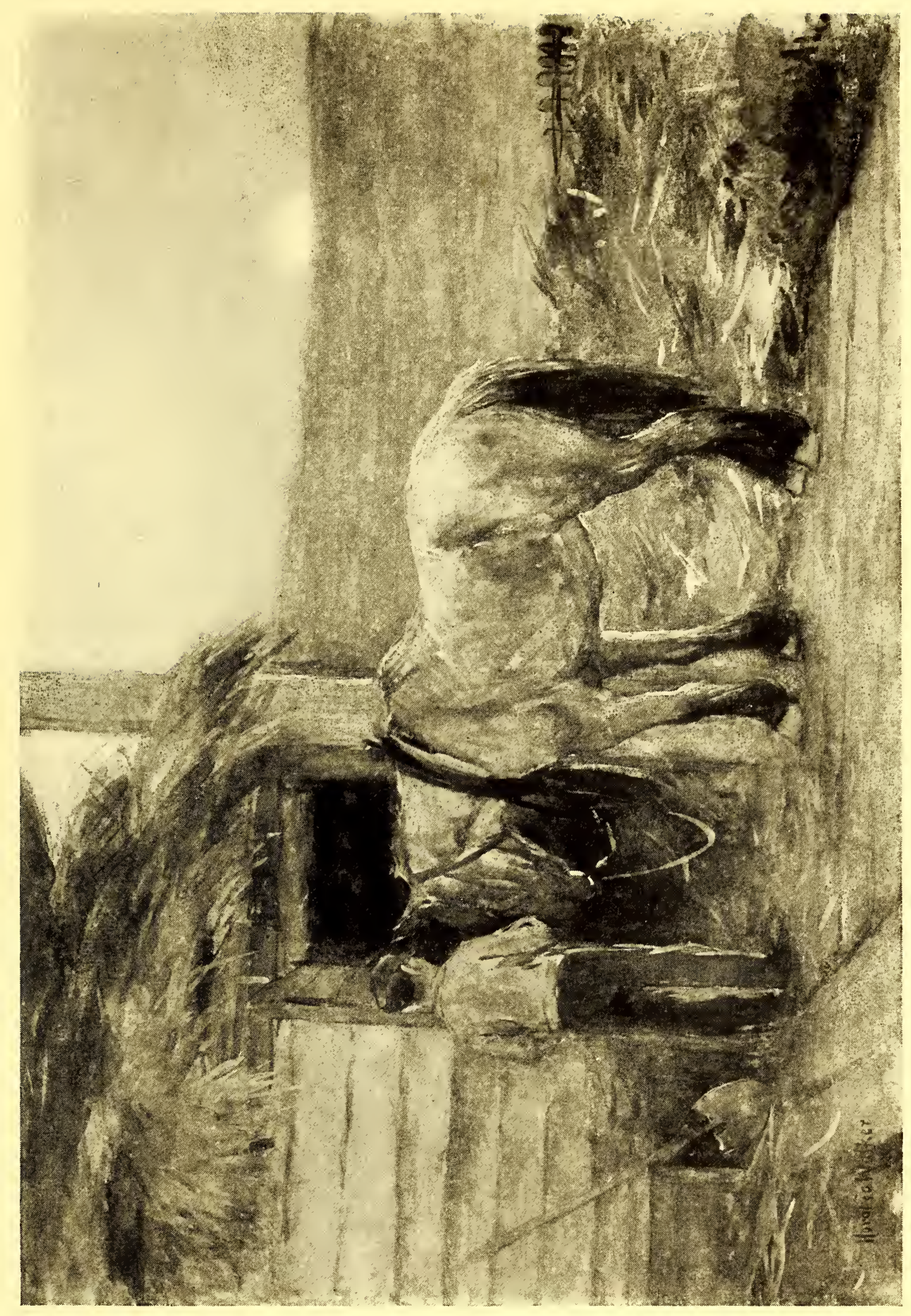


No. 13

\section{CARLTON 'T. CHAPMAN, N.A.}

Americhan : 1860-

\section{THE LIGHTHOUSE}

\section{Height, 14 inches; length, 22 inches}

THE ocean's surging waters occupy the foreground and on the left, in the middle distance, is a headland crowned by a lighthouse. Several vessels are seen offshore with port and starboard lights of green and red, and above is a dark sky of evening. The signal light spreads abroad its rays, which are reflected in the water, and contrasts with the general blue-gray tone of the rest of the picture.

Signed at the lower left.

Thomas B. Clarke Collection, New York, 1899, Catalogue No. 264. 


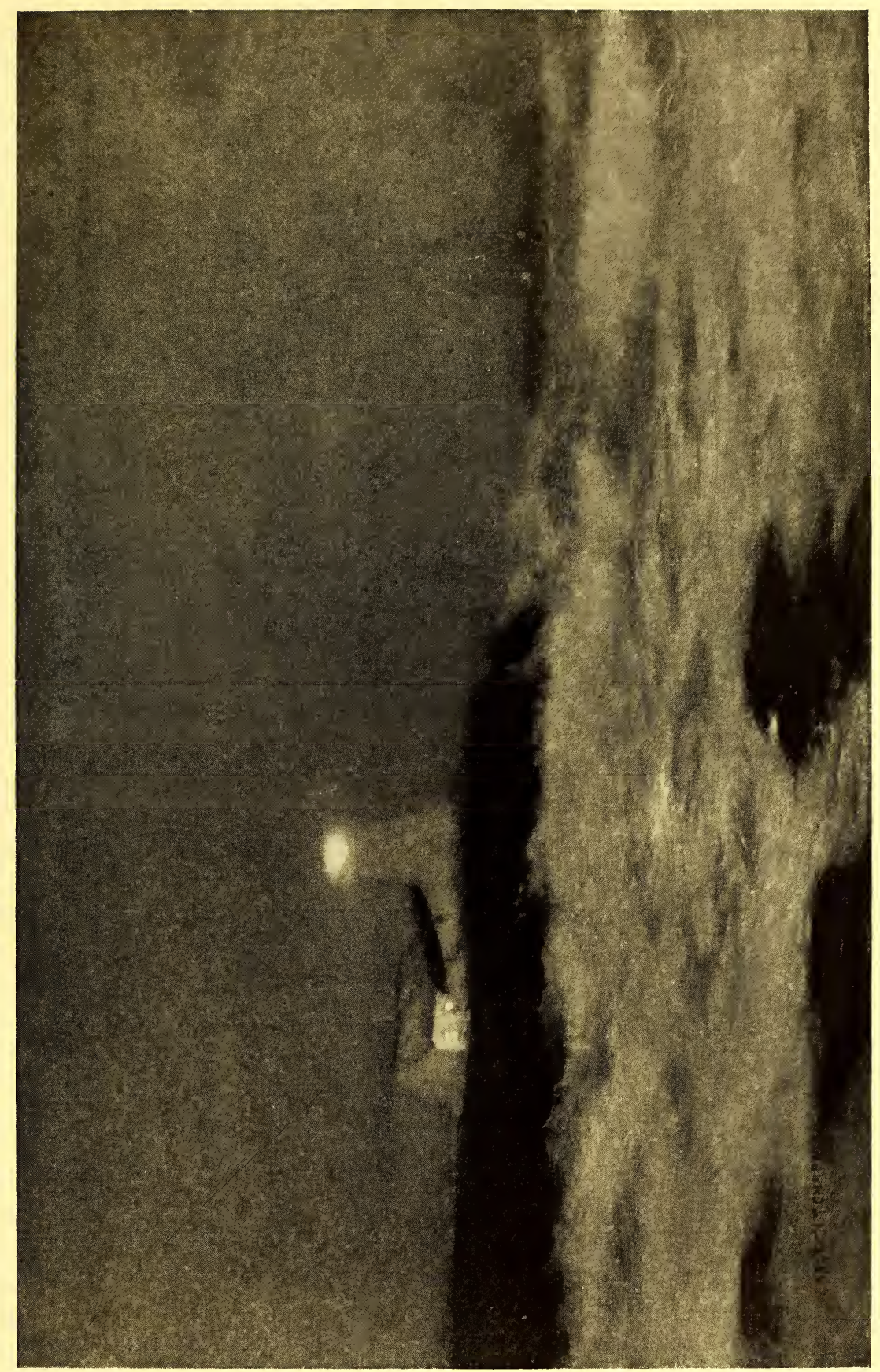




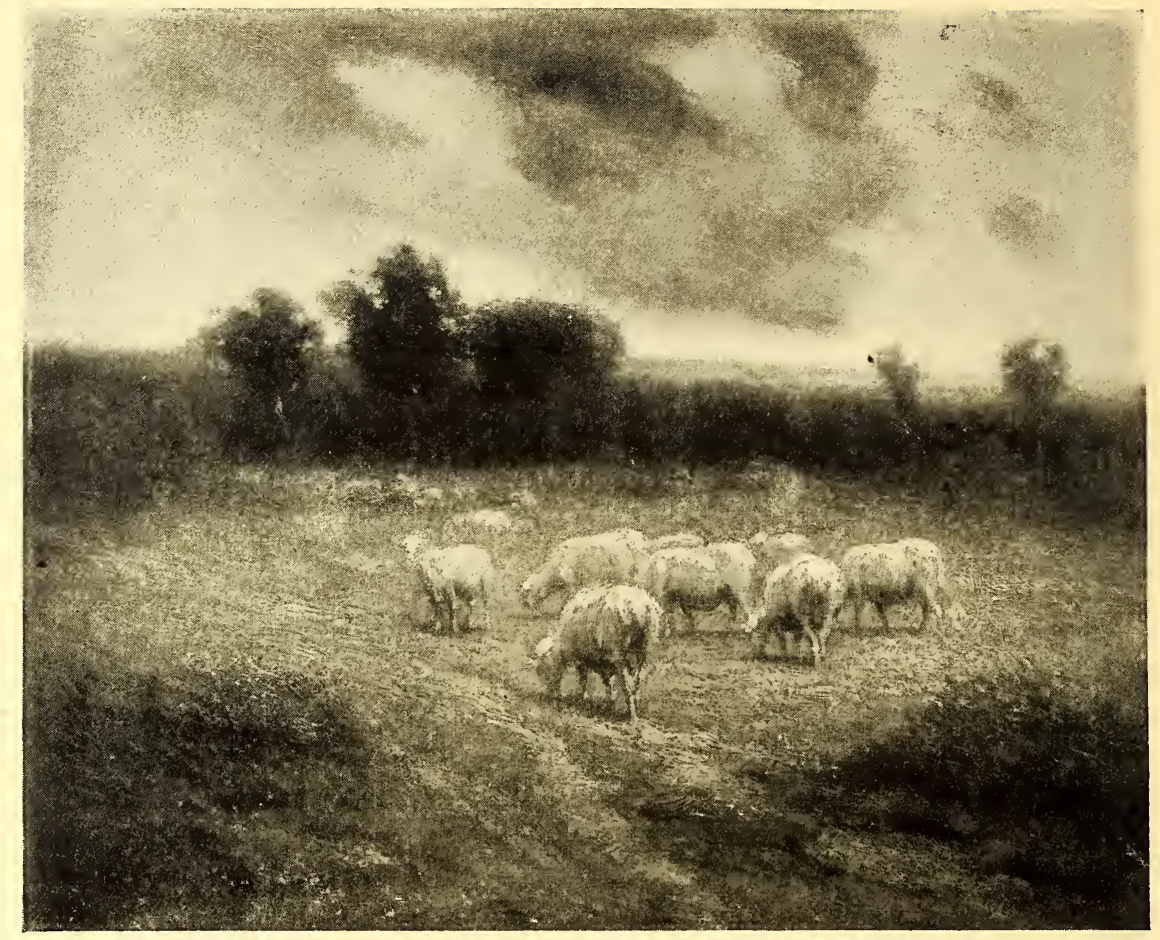

No. 14

\section{CARLETON WIGGINS, N.A.}

American : 1848-

\section{THE STORM}

Height, 13 inches; length, 16 inches

SheEP are seen browsing in the middle portion of the picture, which is illuminated by a gleam of sunlight, while farther away a belt of trees and distant fields lie in shadow from the clouds of a gathering storm.

Signed at the lower left.

Purchased from William Macbeth, New York, 1902. 
No. 15

\section{CHARLES WEBS'TER HA W'THORNE, N.A.}

American: 1872

\section{ALONG THE RIVER}

Panel: Height, 171/2 inches; length, 191/2 inches

From the left foreground a quay extends into the middle portion of the picture, with a wide expanse of river on. the right. Houses line the quay, a sailing vessel is moored near the center of the composition, and beyond, at the right, on the farther shore, are buildings, including one with a dome. Overhead is a sky of blue with masses of white clouds.

Signed at the lower left.

Purchased direct from the artist, 1908.

No. 16

\section{CHARLES HAROLD DAVIS, N.A.}

American : 1856-

\section{SUNSET ON THE MOOR}

Height, 15 inches; length, 211/2 inches

The lower part of the picture is occupied by a level plain and a winding stream. At the horizon is a line of trees. The sky, with tinted clouds in the upper portion, shows warm yellow and pink below, and here and there is a space of blue.

Signed at the lower left.

Thomas B. Clarke Collection, New York, 1899, Catalogue No. 14. 
No. 17

\section{R. SW AIN GIFFORD, N.A.}

American: $1840-1905$

\section{SOLITUDE}

Height, 14 inches; length, 23 inches

A PICTURe of quiet general tone, showing stretches of beach and an inlet, in the foreground. The middle distance presents a strip of country, rising somewhat steeply, and above is an evening sky, just after sunset, showing great cloud masses, illumined, in the right center of the composition, with warm white and pink.

Signed at the lower left.

Purchased from William Macbeth, New York, 1905. 


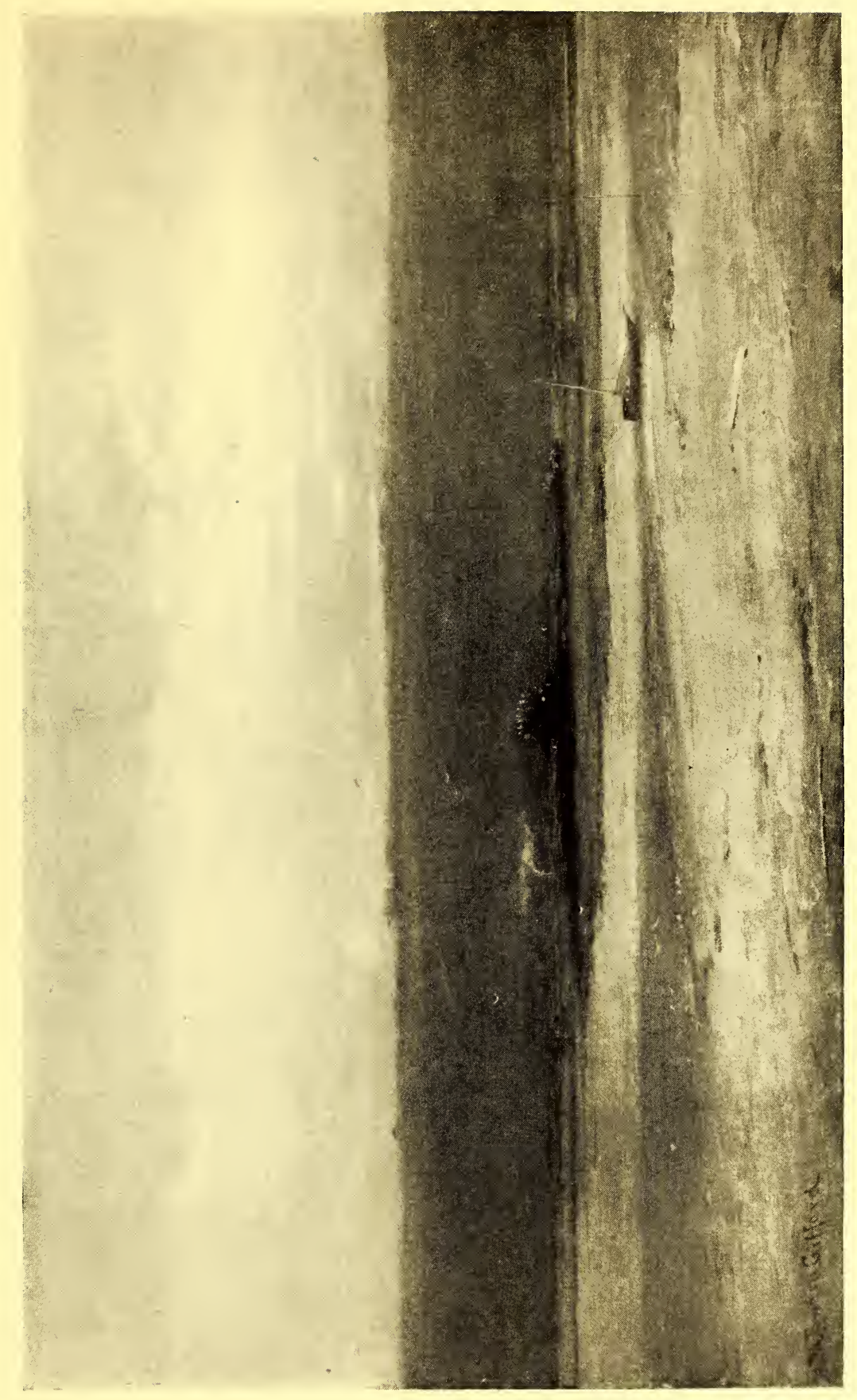


No. 18

\section{ALEXANDER H. WYAN'T, N.A. $\quad x x^{x}$}

Americax: $1836-1892$

A GRAY DAY

Height, 14 inches; length, 22 inches

A LandsCape with the simple elements of a meadow and a little pool in the foreground, a tree in the middle portion and some bushes and underbrush crossing the canvas beyond. 'The sky is filled with gray clouds, some of them illumined, from the right, by pale sunlight. 'The general aspect of the picture exhibits the unobtrusive quality of Wyant's pastoral scenes.

Signed at the lower left.

Purchased from William Macbeth, New York, 1902. 


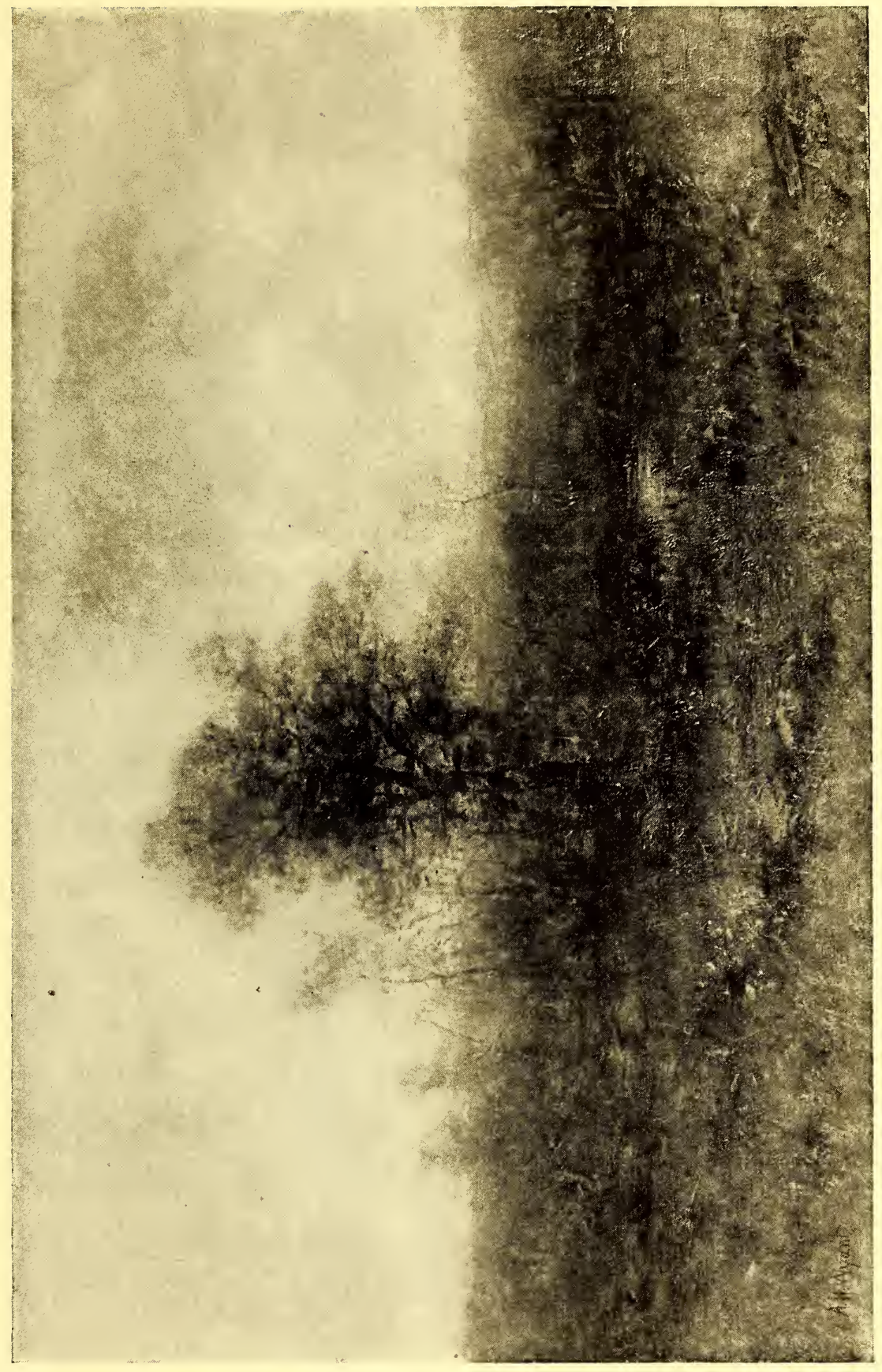


No. 19

\section{HENRY GOLDEN DEARTH, N.A.}

Americhin: 1864-

\section{GRAY WEATHER}

Panel: Height, 121/2 inches; length, 16 inches

A marine of charming color quality, showing a rock in the middle foreground with the waters swirling around it. Beyond lies the ocean, with a strip of sky at the top of the picture. The color scheme shows notes of blue, green, white and violet, all consistently unified.

Signed at the lower right.

Purchased direct from the artist, 1912.

No. 20

HOMER D. MAR'TIN, N.A.

Anericax : $1836-1897$

\section{LOW TIDE--HONFLEUR}

Height, 15 inches; length, 24 inches

A saxdy beach occupies the foreground, with a thatched hut, near the middle of picture, and a line of blue hills beyond. The sea has apparently run out of a narrow channel at the base of the hills. Orerhead is a sky of gray.

Signed at the lower left.

Purchased from Wm. Macbeth, February, 1907. Mr. Macbeth purchased the picture from Mrs. Agnes Farley, 16 Rue de la Paix, Paris, to whom the picture was presented by Homer Martin about the time it was painted. Letter from Mrs. Farley and a certificate by Wm. Macbeth confirming these facts will be presented to the purchaser. 
No. 21

\section{ALEXANDER H. WY AN'T, N.A.}

American : $1836-1892$

KILLARNEY

Height, 12 inches; length, 20 inches

A Wyant of his earlier period, remarkable for its mellow tint and unity. The Lake is seen lying amid the hills in the middle portion of the picture, while in the foreground there is an eminence denuded of the herbage which covers all the rest of the ground. Above a mass of gray clouds, quite dark at the horizon, appears the high peak of a distant hill.

Signed at the lower left, and dated $186 \%$.

Purchased from Mrs. A. H. Wyant, 1902.

No. 22

RICHARD PAULI

American: $1855-1892$

A GRAY DAY

Panel: Height, 16 inches; length, 24 inches

A LANDSCAPE in greens and varied grays, the elements of the picture being level meadows, clumps of trees and greensward, in the foreground and middle distance. Beyond is a belt of trees and above is a sky of clouds, breaking up after a shower.

Signed at the lower right.

G. Harrison Collection, New York. 
No. 23

\section{JULIAN RIX \\ American : $1851-1903$}

\section{THE QUARRY}

Height, 16 inches; length, 23 inches

AN autumn effect in sunlight with foreground of grass, herbage and rocks. A tree, with dark foliage, near the middle of the composition, with a strong note of white where the sun illuminates its trunk, gives a keynote amid the foliage masses of warm color on other trees, both near and far away. Overhead is a sky of puissant blue flecked with many clouds.

Signed at the lower right, and dated '98. 


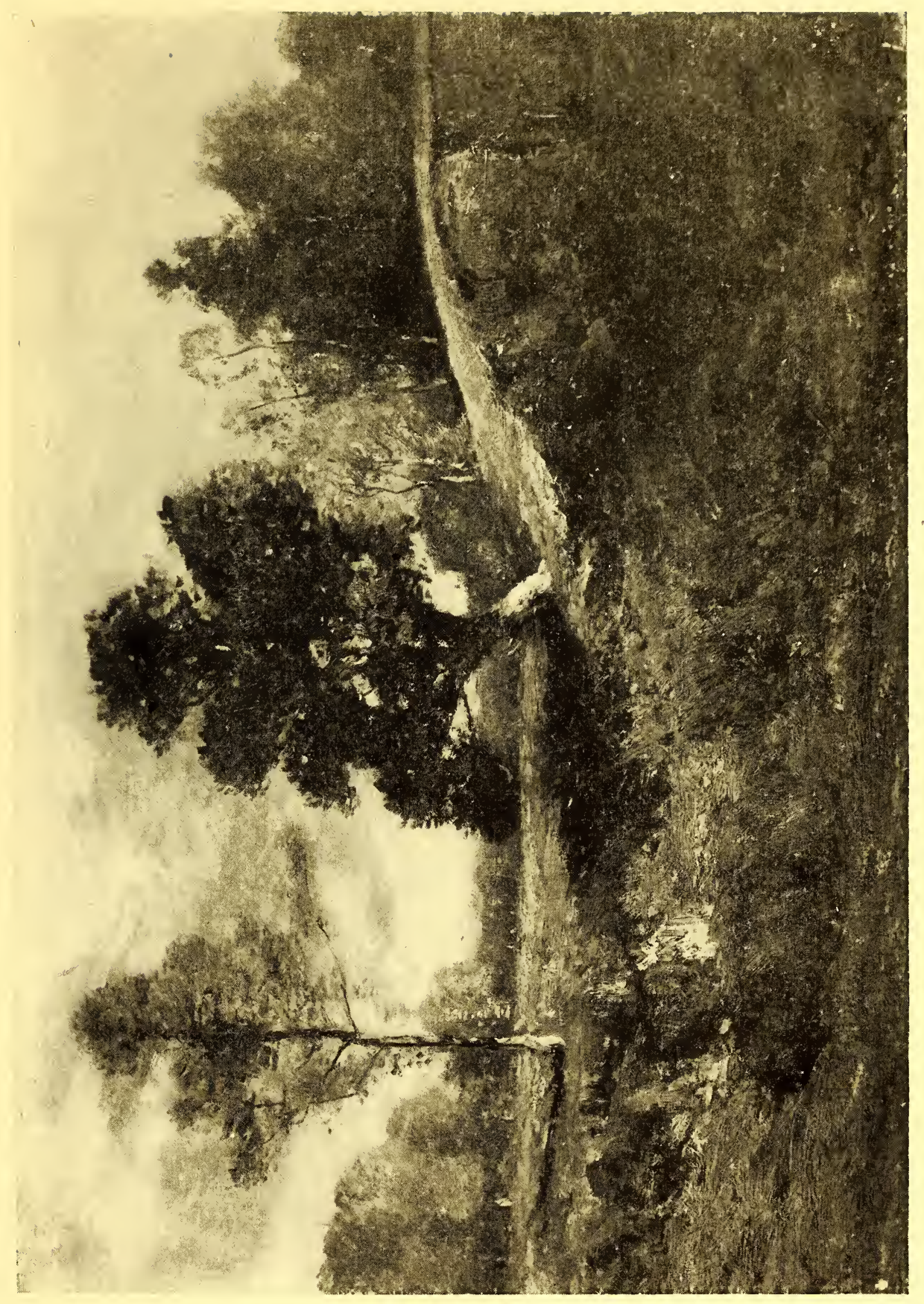




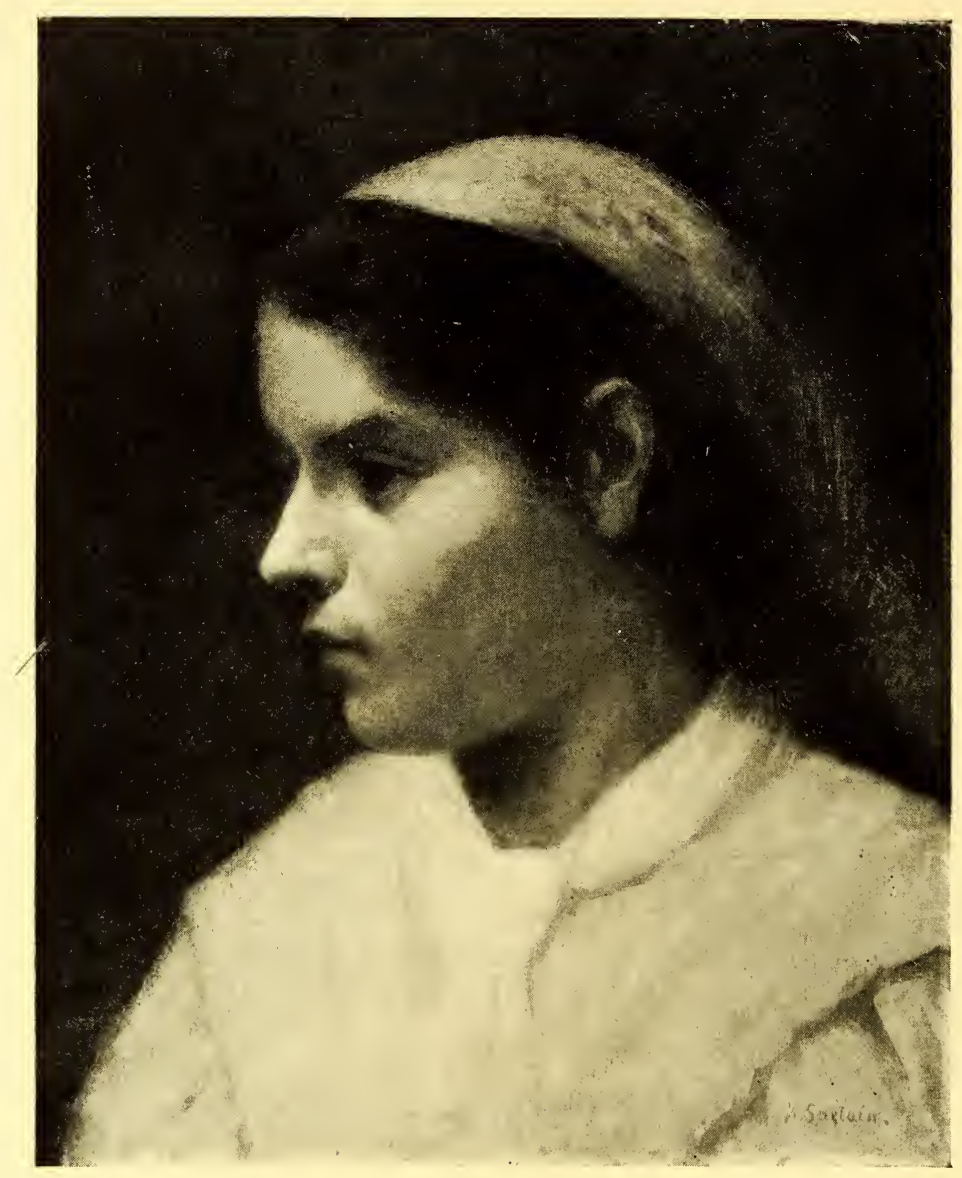

No. 24

WILLIAM SARTAIN, A.N.A.

American: 1843-

ITALIENNE

Height, 18 inches; width, 15 inches

A LIFE-size head in profile, to the left, of an Italian girl with black hair and a head-dress of yellow. The shoulders are covered by a white waist and kerchief.

Signed at the lower right.

Purchased from William Macbeth, 1905. 
No. 25

\section{WILLIAM MORRIS HUN'T}

Americhn : 1824-1879

\section{HEAD OF A SPANISH GIRL}

\section{Height, 24 inches; width, 18 inches}

A HEAD and bust picture of a young woman, in profile view to the right, wearing a headdress of red and yellow and a white bodice. The head inclines slightly forward and is modeled with simplicity.

Signed with monogram, at center right.

Mrs. Susan D. Warren Collection, New York, 1903, Catalogue No. 82. Purchased from William Macbeth, New York, 1905.

No. 26

\section{FRANK KNOX MORTON REHN, N.A.}

American : 1848-1915

\section{IN MID-OCEAN}

Height, 16 inches; length, 24 inches

A night effect at sea with the full moon, which has risen well above the horizon, casting its light on the tumbling waves. In the offing, in the right center on the horizon, a steamer is seen making its way along with smoke pouring from the funnel. The moon is placed in the middle of the upper part of the sky, and the reflection of the light on the waters occupies the middle portion of the picture. 
No. 27

\section{ALEXANDER H. WY ANT, N.A.}

American : $1836-1892$

\section{COUNTY KERRY, IRELAND}

Height, 15 inches; length, 221/2 inches

THIs landscape presents a view amid the hills of Ireland and belongs to a series of pictures painted by Wyant during his visit to that country in the early sixties. In the foreground is a bit of water with boulders scattered about, and a road leading through the valley into the gaps between the hills beyond. Overhead is a sky of broken gray clouds.

Signed at the lower right, and dated 1866.

Purchased from Edward C. Stedman, New York, 1905. 


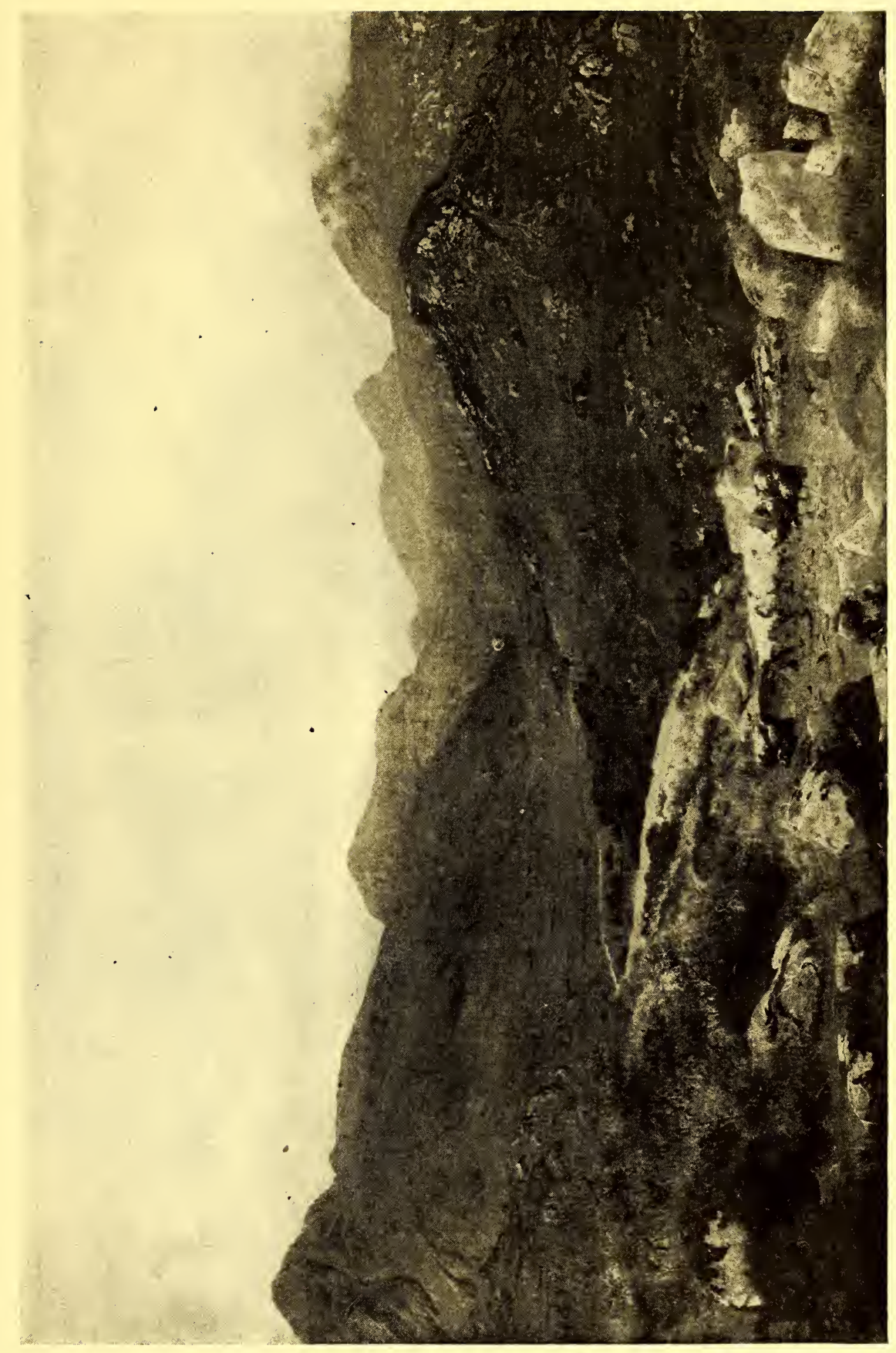


No. 28

\section{FREDERICK BALLARD WILLIAMS, N.A}

American : $1871-$

\section{VALLEY OF THE PASSAIC}

\section{Height, 16 inches; length, 24 inches}

A landscape in September effects, in which the chief elements are a tree, in the left foreground, with foliage of tawny yellow and brown, rocky hills in the middle distance and a view of the valley on the right. The sky is of qualified blue with white and gray clouds.

Signed at the lower right.

Purchased direct from the artist, $190 \%$. 


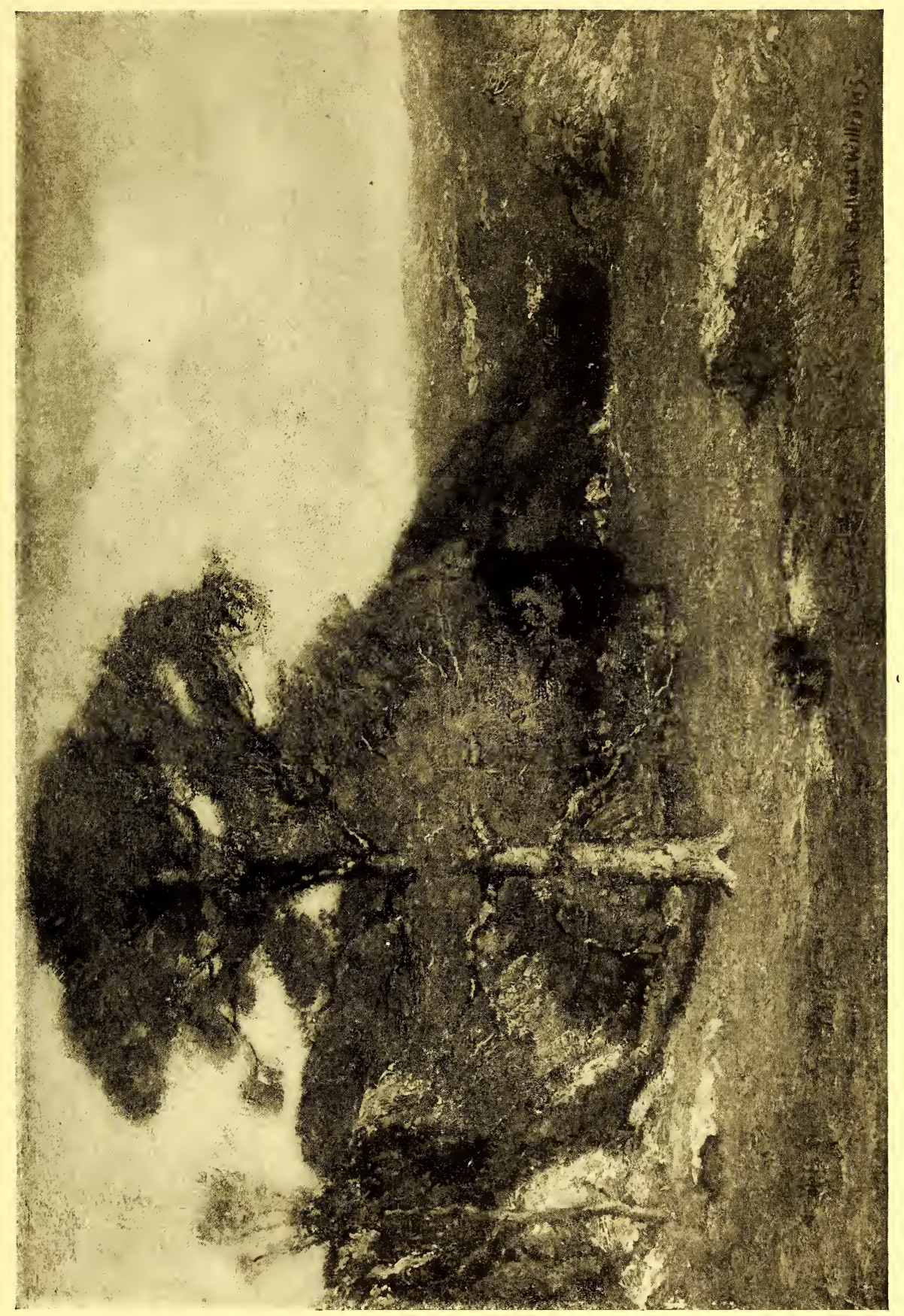




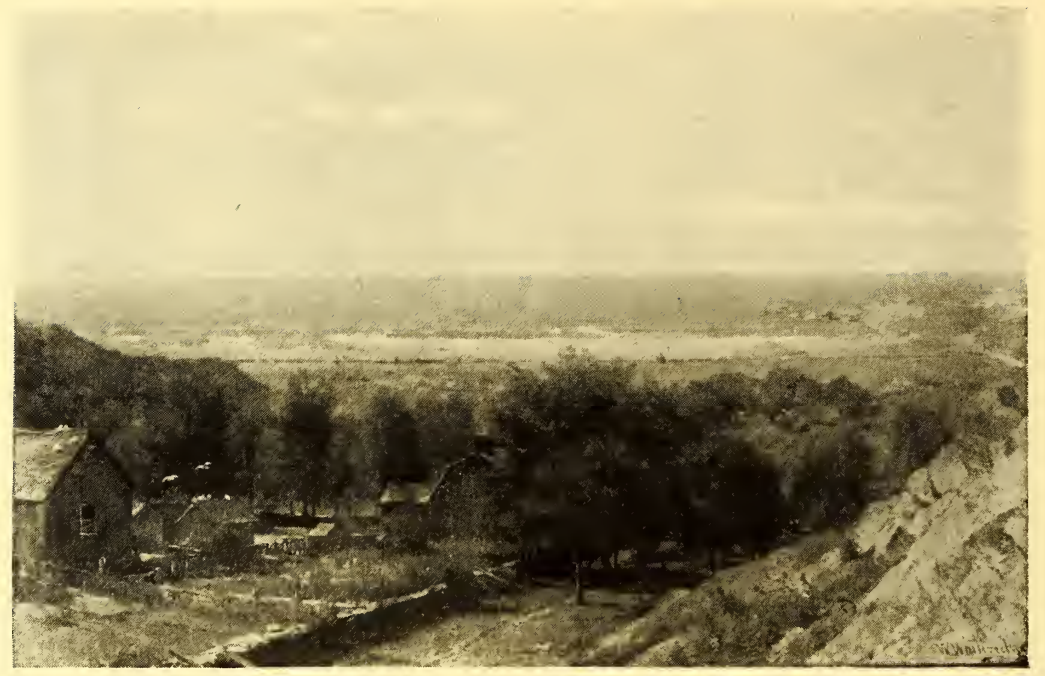

No. 29

\section{WORTHINGTON WHITTREDGE, N.A.}

Americhin : $1820-1910$

\section{A VILLAGE BY THE SEA}

Height, 15 inches; length, 22 inches

A LANDSCAPE especially notable for its beautiful drawing and firm construction. The view, from high ground, overlooks the houses, gardens and trees of a village, and farther away lie flat beaches, beyond which is seen the blue sea with the waves breaking into lines of white surf as they roll slowly in to shore. Overhead is a somewhat misty summer sky of pale blue with warm-tinted white clouds. The entire landscape is bathed in pleasant sunshine.

Signed at the lower right.

Thomas B. Clarlie Collection, New York, 1899, Catalogue No. 321. 


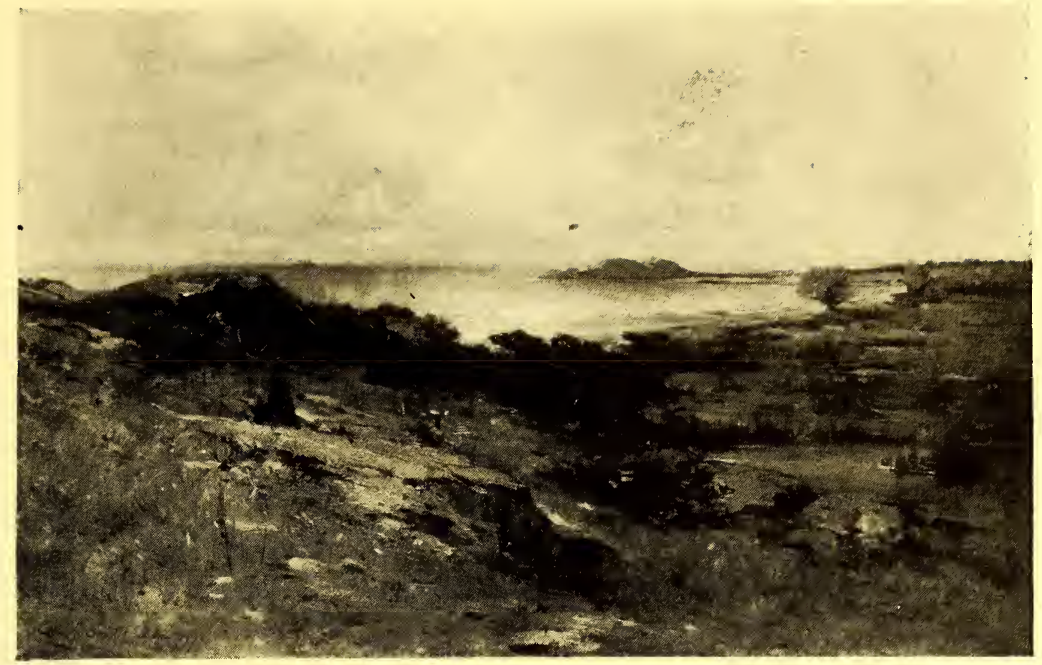

No. 30

\title{
GEORGE HENRY SMILLIE, N.A.
}

\author{
Americhn: 1840-
}

\section{AT EAST GLOUCESTER}

\section{Height, 16 inches; length, 24 inches}

A shore view on a fine autumn day. Clumps of bushes and herbage, rocks, marshes and a pool, filling the foreground, are depicted with a variety of gay tints, and the sea lies beyond, reflecting on its calm surface a sky of delicate white-gray clouds with a space of blue at the right.

Signed at the lower left, and dated 1899.

Purchased at the National Academy of Design, 1899, Catalogue No. 189. 


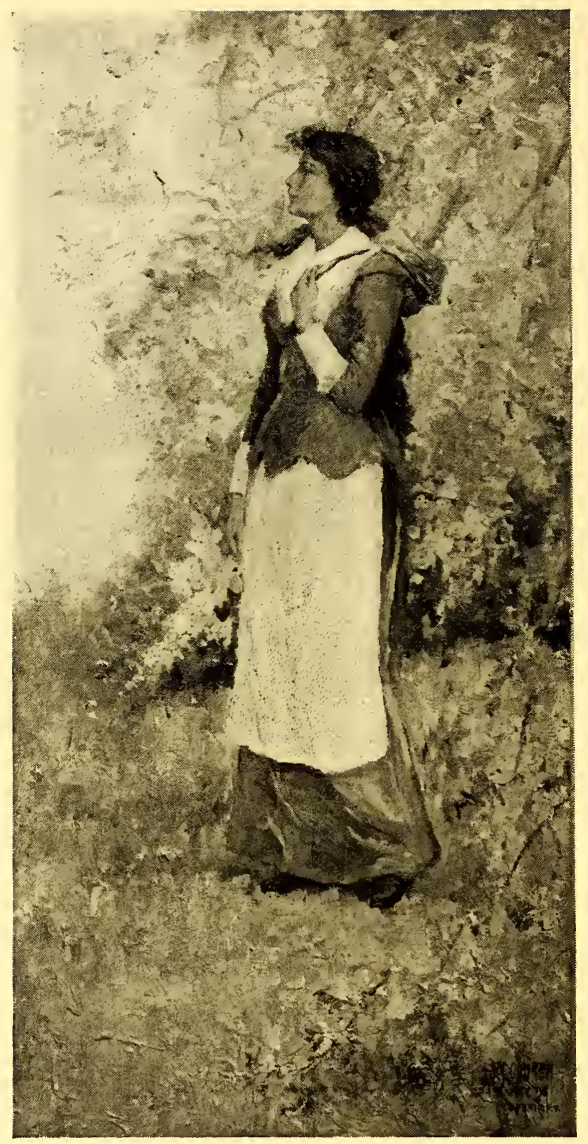

No. 31

\title{
FREDERICK S. CHURCH, N.A.
}

\author{
American : 1842-
}

\section{SPRING SONG}

Height, 24 inches; width, 12 inches

A Fuld-Length figure of a young girl with auburn hair, the head uplifted and seen in profile view, standing near an apple tree in blossom. Light tints of green and pink form a pleasing contrast in the ensemble to the gray and white of the maiden's Puritan costume.

Signed at the lower right, dated '96, and Copyright. William T. Evans Collection, New York, 1900, Catalogue No. $2 \%$. 
No. 32

\title{
HENRY GOLDEN DEARTH, N.A.
}

\author{
American : 1864-
}

\section{BRITTANY COAST}

Panel: Height, 18 inches; length, 211/2 inches

In the foreground, both on the right and left, are rocky formations, rather square and regular in shape, forming a channel through which the sea is rushing and breaking into white foam, while water also dribbles over the rocks. In the upper half of the picture appears the wide expanse of the ocean, green tempered with lilac. At the top of the canvas is a headland and a narrow strip of sky.

Signed at the lower right.

Purchased direct from the artist, New York, 1912.

No. 33

\section{CHARLES WEBSTER HAW'THORNE, 'N.A} American: 1872

\section{THE GRAND CANAL-VENICE}

Panel: Height, 20 inches; width, 1\%1/4 inches

A vIEw looking through the Canal with buildings on either side. The sky, of tempered blue with some white cloud masses, is reflected, in lower values, in the water.

Signed at the lower left.

Purchased direct from the artist, New York, 1908. 
No. 34

\section{JULIAN RIX}

American : $1851-1903$

\section{SINGAC MEADOWS}

\section{Height, 16 inches; length, 24 inches}

A Landscape of midsummer effects, with green meadows occupying the foreground and groups of full-foliaged trees on both the right and left. In the distance is a vista of diversified country, and overhead a blue sky with masses of warm-tinted white clouds. The central portion of the picture is brought into relief by heavy shadows across the foreground.

Signed at the lower right.

Purchased direct from the artist, 1899. 


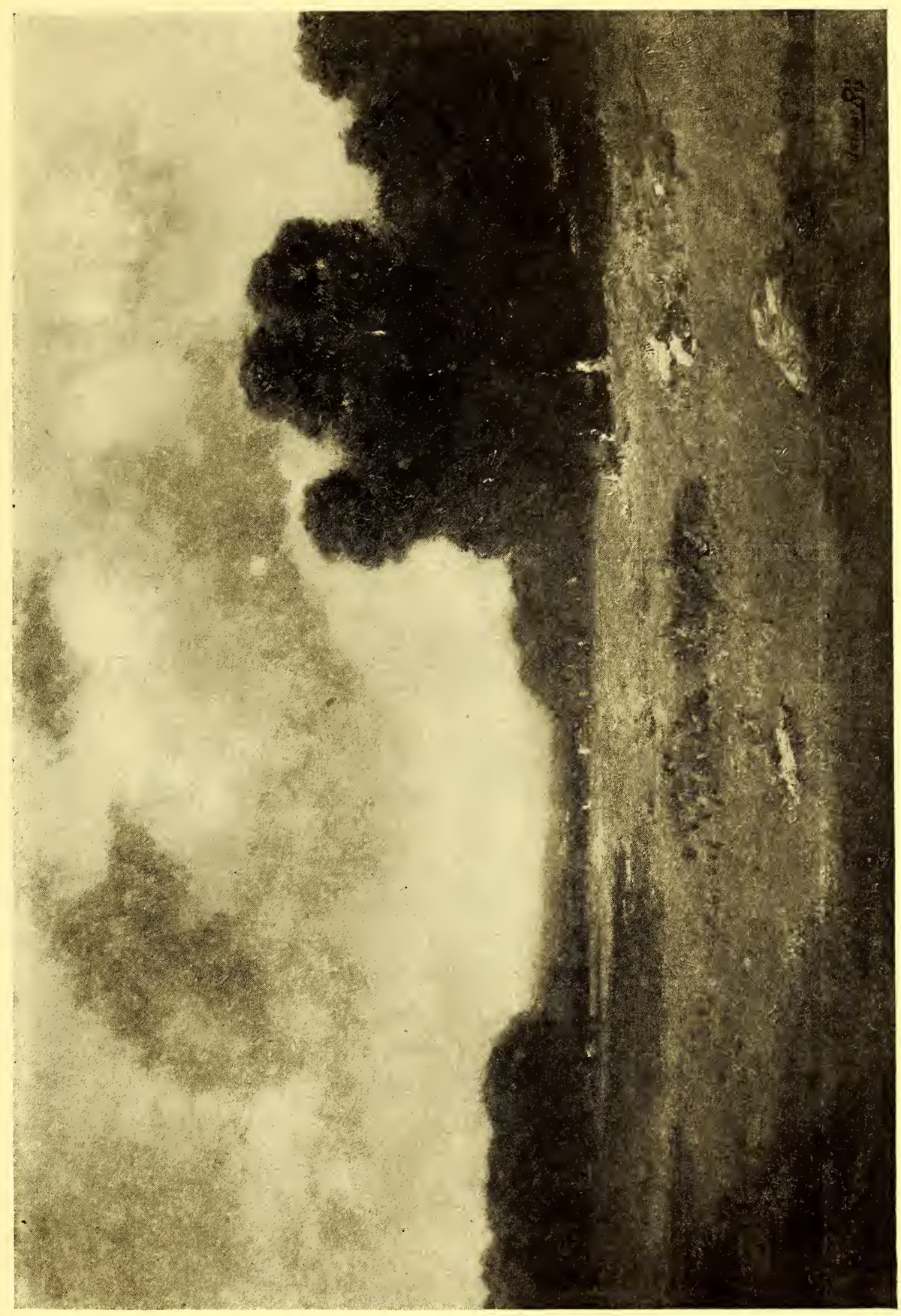


No. 35

\section{WILLIAM HENRY HOWE, N.A.}

American :

\section{ON THE MARSHES-HOLLAND}

Height, 181/2 inches; length, 231/2 inches

A GROUP of cattle, two standing and others lying down in a flat pasture, through which passes a narrow stream. A belt of trees is seen in the middle distance, and beyond appear a windmill and line of hills. The gray sky shows a space of blue in the upper left portion. The cows are white, spotted, and red and black.

Signed at the lower left, and dated '98.

No. 36

\section{GEORGE HITCHCOCK, A.N.A.}

American : $1850-1913$

\section{WINDMILL AND GEESE}

\section{Height, 23 inches; width, 173/4 inches}

A Holland landscape, with a plain covered with coarse grass and herbage of various kinds occupying more than half of the canvas, across which a flock of geese is making its way toward a mill and stone bridge, in the distance. Still farther away appear a spire and roofs indicating a town on the horizon. Overhead is a sky of gray.

Signed at the lower left.

Boussod, Valadon \& Co. Collection, New York, 1902, Catalogue No. 141. 


\section{WILLIAM SAR'TAIN, A.N.A.}

American : 1843 -

\section{ARAB CAMP-OUTSIDE THE WALLS}

Height, 18 inches; length, 24 inches

A Low-tone picture with forceful coloring, depicting three Arabs, clothed in white, seated on the ground in the middle center of the composition. Behind them a white wall runs across the canvas and there are two tents on the right. Over the wall appear a grove of trees and spaces of blue sky. The light is concentrated on the figures and the central portion of the wall.

Signed at the lower right.

Purchased from William Macbeth, New York, 1905.

No. 38

\section{FREDERICK S. CHURCH, N.A.}

American: 1842-

\section{A SURF PHANTOM}

Height, 20 inches; length, 24 inches

A fantasy, representing a sea nymph with heavy blond hair, riding in the surf, which, as it whirls upward in a breaker, assumes a resemblance to a white steed.

Signed at the lower right, and dated N. Y. '85.

Thomas B. Clarke Collection, New York, 1899, Catalogue No. 31. 
No. 39

\title{
FRANK KNOX MORTON REHN, N.A.
}

\author{
Americhin: $1848-1915$
}

\section{MARINE}

Height, 16 inches; length, 28 inches

Breakers are rolling in-shore in the foreground, spreading out and covering the beach, while the expanse of the ocean fills the middle distance and is illuminated by light falling from the sun, which is above and out of the picture. A white sail or two catch the light on the horizon.

Signed at the lower left, and dated '91. 


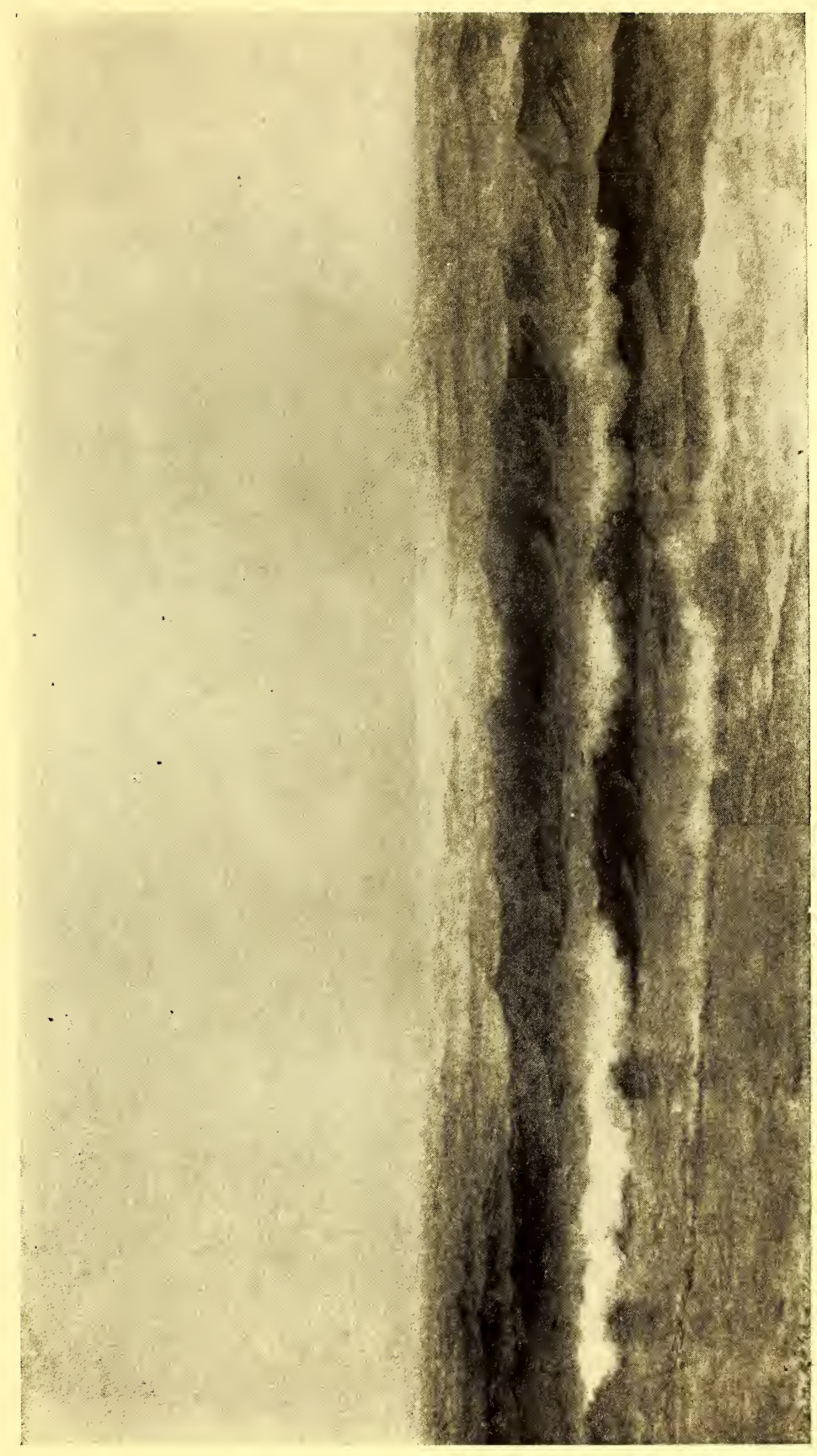


No. 40

\section{CHILDE HASSAM, N.A.}

American : 1859-

\section{ON THE AVENUE IN WINTER}

Height, 24 inches; width, 22 inches

An example of the artist's city scenes in winter, showing a street, with a figure of a lady on the sidewalk in the foreground; other pedestrians beyond and, in the roadway, a number of cabs. The effect shows melting snow which has not yet been cleared away.

Signed at the lower right, and dated 1905. 


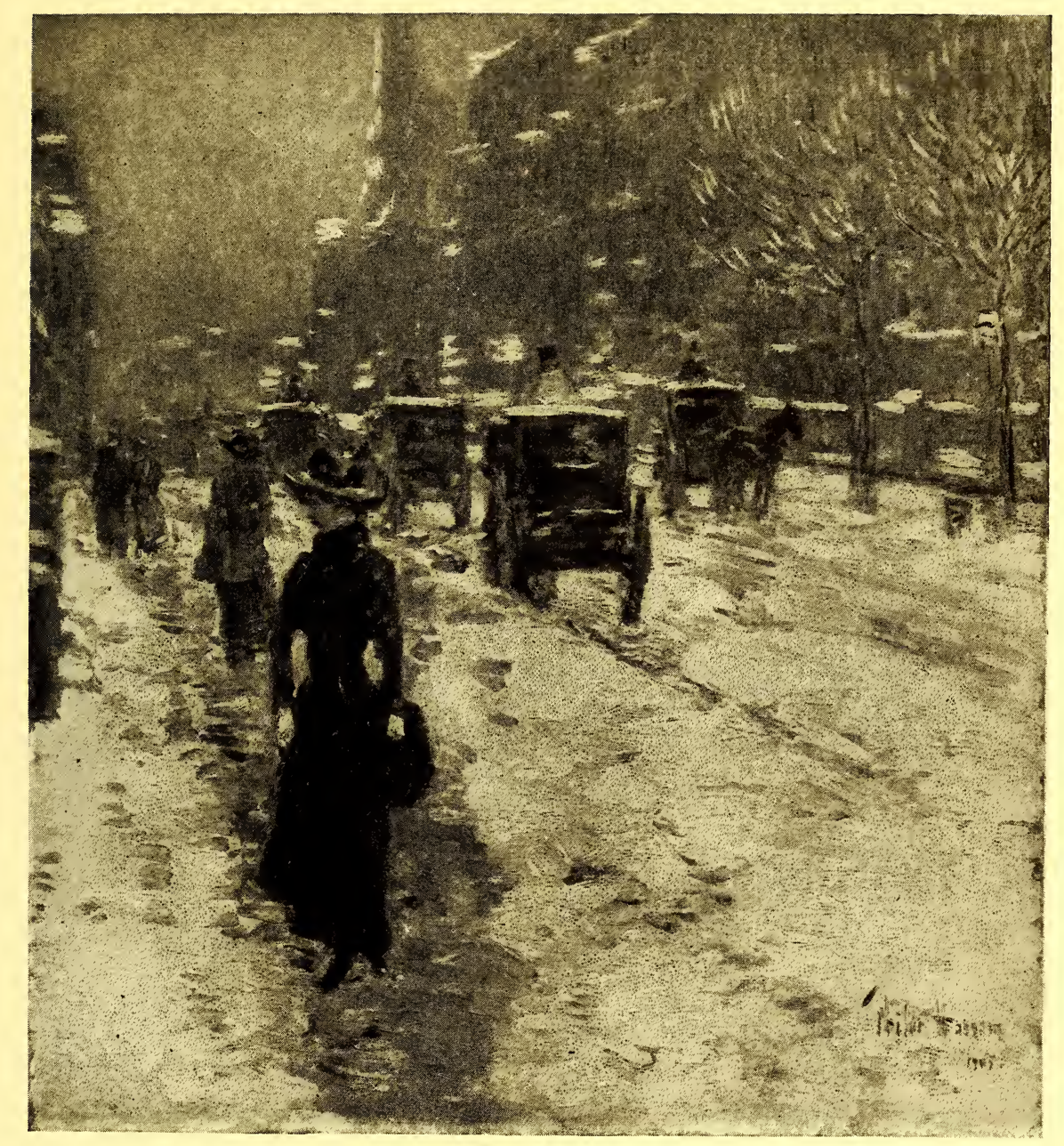


No. 41

\section{CHARLO'T'TE BUELL COMAN, A.N.A.}

Axierican: Contemporary

IN THE FALL OF THE YEAR

Height, 27 inches; width, 221/2 inches

A QUIET, restful landscape, showing a view of a broad valley from heights in the foreground, where a group of trees in autumn foliage and one or two buildings are seen. The vista beyond covers fields and belts of timber, extending to a line of distant hills near the top of the canvas, where there is a space of gray sky.

Signed at the lower left.

Purchased from William Macbeth, New York, 1908.

No. 42

HENRY GOLDEN DEARTH, N.A.

American: 1864-

ANEMONE POOL

Panel: Height, 18 inches; length, 211/2 inches

A color arrangement, belonging in the artist's so-called "Pool Series." The picture shows a sort of square basin amid the rocks on the seashore, filled with water and not only reflecting objects on shore, but also showing in places the bed of the pool. At the upper right of the canvas appears a stretch of the ocean with a headland and strip of sky.

Signed at the lower left.

Purchased direct from the artist, New York, 1912. 
No. 43

\section{CHARLES HAROLD DAVIS, N.A. \\ American: 1856}

\section{SUMMER CLOUDS}

Height, 20 inches; length, 27 inches

A LANDSCAPE composed of the simple elements of a plain, with a line of hills in the distance, and a spacious sky. The greater part of the plain, occupying not only the foreground but a portion of the middle distance, is in shadow. Just at the farther edge appear a few hillocks and trees, and in the shadowed portion itself is a flock of sheep with its shepherd. A high sky is filled with masses of clouds floating in the blue. It is because of the sun being behind one of these large clouds that the whole foreground and part of the middle distance are in shadow.

Signed at the lower left.

No. 44

\section{GEORGE INNESS, JR., N.A.}

American: 1854-

\section{IN THE COOL OF THE EVENING}

Height, 211/4 inches; length, 25\% $/ 4$ inches

The composition shows a group of cattle and some sheep, in a setting of pasture, on the edge of a dense forest. The light is concentrated on the animals, while the rest of the picture is subdued to lower tones.

Signed at the lower right. 
No. 45

\section{HENRY WARD RANGER, N.A. \\ American : 1858-1916}

\section{SPRING-EAST LYME}

Height, 18 inches; length, 251/2 inches

A BRIGHT, sunny spring landscape with a river crossing the foreground. A fisherman in his boat at the nearer shore, trees, a white house and some cows on the opposite bank are other features of the composition. In the sky of blue are warm-tinted white cumulus clouds.

Signed at the lower left, and dated '99.

Purchased from Arthur Tooth \& Sons, New York, 1899.

No. 46

WILLIAM SAR'TAIN, A.N.A.

Anerichin: 1843-

THE CLOUD

Height, 20 inches; length, 24 inches

Aвove a foreground of salt marshes and an inlet of the sea is a wide expanse of sky with a great mass of cloud, the upper portion lighted by the sun. Beneath it are wind-swept forms of gray; in the upper right of the canvas, a bit of blue.

Signed at the lower right.

Purchased from William Macbeth, New York, 1903. 
No. 47

\title{
WILLIAM MORRIS HUN'T
}

\author{
American : 1824-1879
}

\section{OLD MEXICO}

Height, 20 inches; length, 27 inches

Three horsemen are seen passing across a sandy foreground. On the left is an eminence crowned by a shrine; on the right, a low building with white walls; hills in the distance.

Purchased from William Macbeth, New York, 1906.

No. 48

\section{JULIAN RIX}

American : 1851-1903

\section{EDGE OF THE WOOD}

Height, 211/2 inches; length, 28 inches

The view in this landscape is taken from within the woods and presents, in the distance, a glimpse of forest and hills. The sombre masses of the wood interior are relieved by the white trunk of a beech tree, which is seen in the foreground.

Signed at the lower right, and dated 1899.

Purchased direct from the artist, New York, 1899. 
No. 49

\section{CHARLES COUR'TNEY CURRAN, N.A.}

Americhin: 1861 -

\section{GIRL WITH VIOLIN}

Height, 36 inches; width, 161/4 inches

A Full-Length standing figure of a young woman, in lowneck gown of wine color, seen in full face view, the head inclined to right, as she plays her violin and with her right hand draws the bow down to the end. 'The figure is illumined by light coming from the left and the color scheme shows warm tones throughout.

Signed at the lower right, dated 1905, and Copyright.

'Purchased direct from the artist, New York, 1905. 

No. 50

\section{THOMAS MORAN, N.A.}

American : 1837 -

\section{A VENETIAN FIESTA}

Height, 20 inches; length, 30 inches

The familiar setting for pictures of Venice is shown in this picture, consisting of the Doges' Palace, the Campanile, Santa Lucia, and other buildings in the middle distance. In the foreground on the left is a mass of vessels of all kinds, huddled together and showing bright tints of color in the sails, pennants, and other features. A sky of blue, with white clouds, is reflected in the wide expanse of water.

Signed at the lower left, and dated 1899.

Purchased at the National Academy of Design, New York, 1899. 


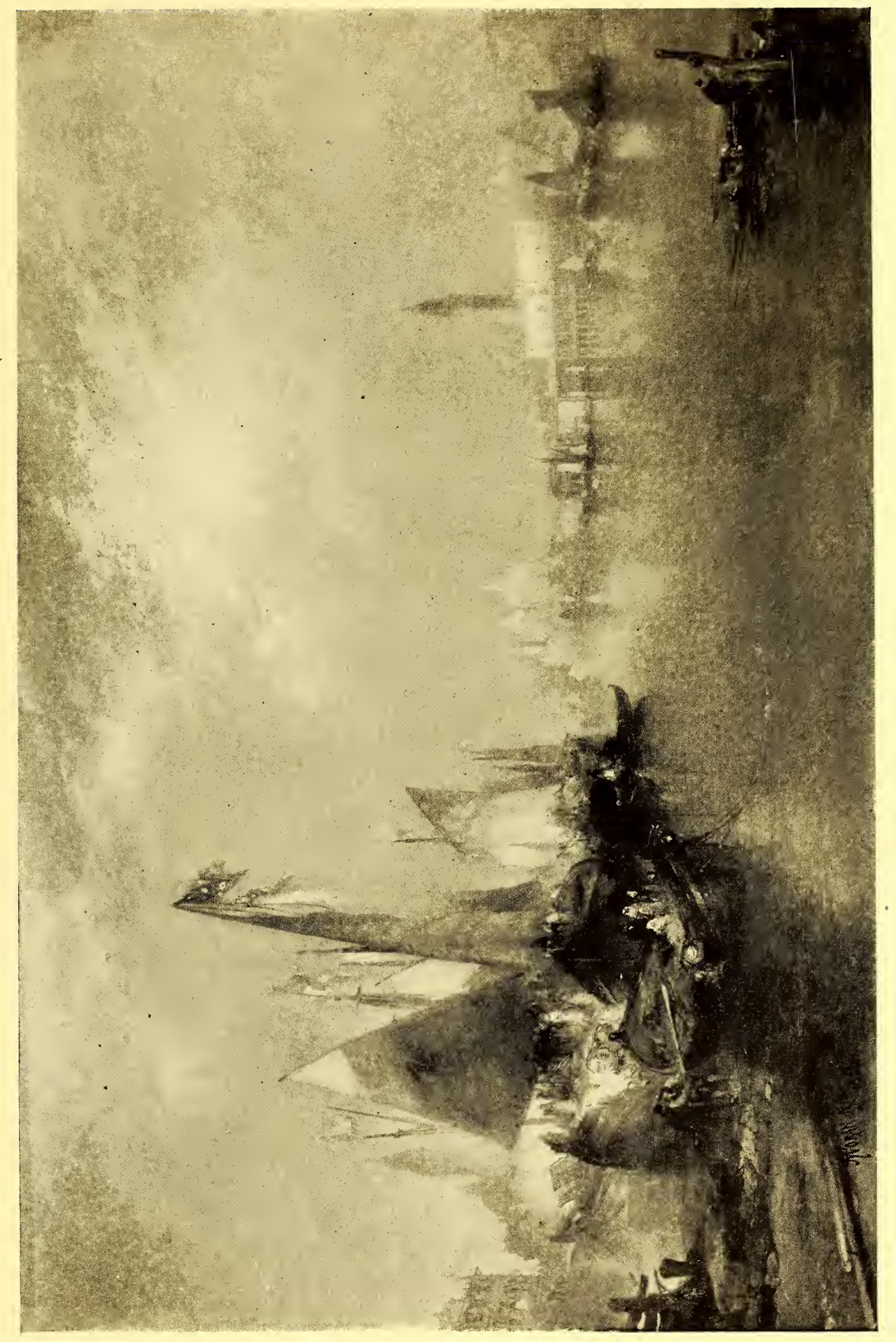


No. 51

\section{HENRY WARD RANGER, N.A.}

American : $1858-1916$

\section{VALLEY OF THE SOMME}

Height, 18 inches; length, 26 inches

A MILL stream is seen in the right foreground with thatchroofed cottages on the bank; in the left foreground, a level plain. In the middle distance are groups of trees with high, stem-like trunks and foliage in the upper part of the picture. Beyond is a glimpse of hills and trees. The sky of warm, light gray clouds shows some spaces of blue and the whole makes a composition of balanced masses of light and dark.

Signed at the lower left, and dated '96.

Purchased from William Macbeth, New York, 1905. 


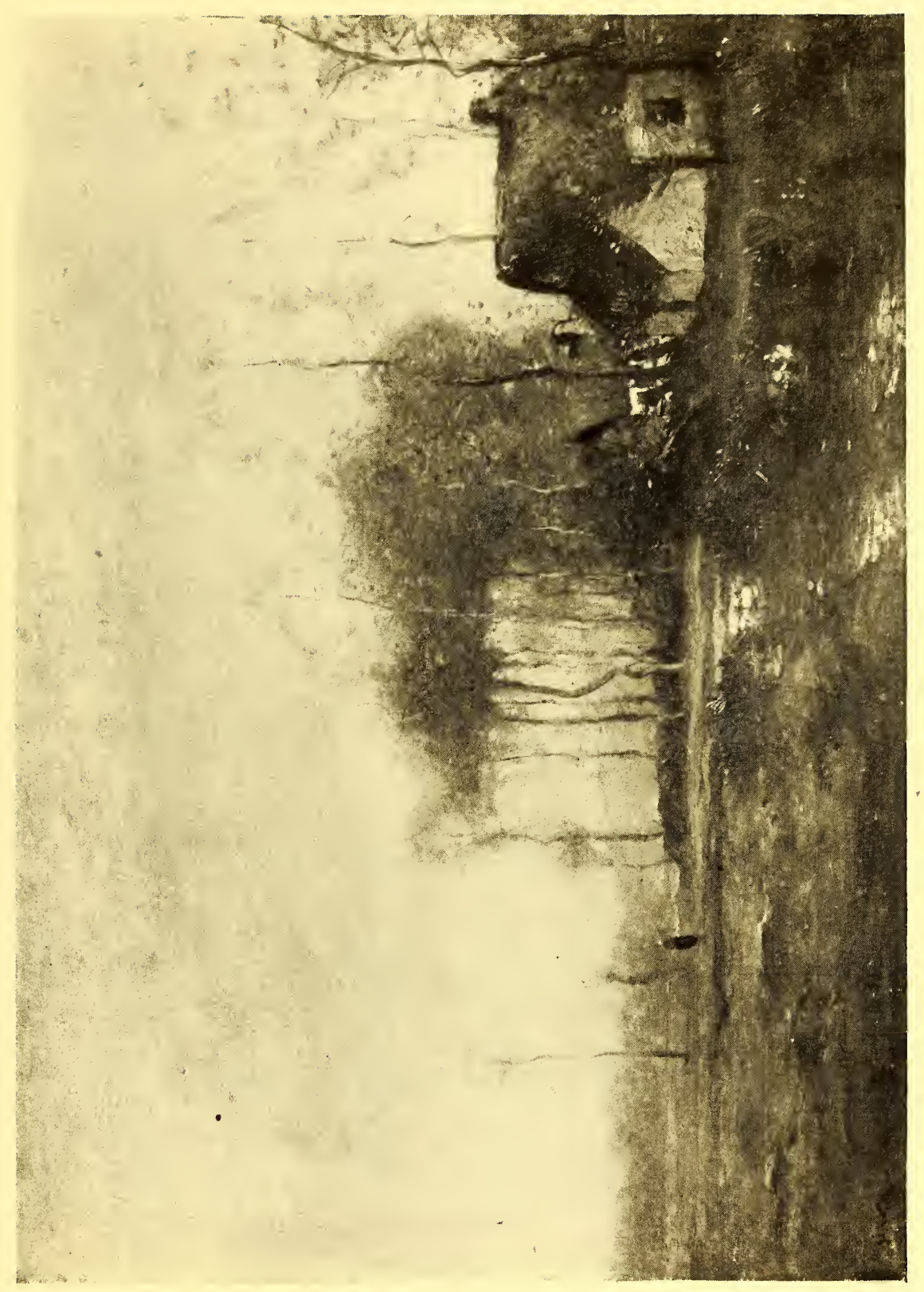


No. 52

\title{
WILLIAM HENRY HOWE, N.A.
}

\author{
American: 1846-
}

\section{YOUNG VAGABONDS}

Height, 24 inches; length, 30 inches

Several young steers, in advance of a herd, are depicted, facing the spectator with direct gaze, in a roadway which leads through sloping pasture lands. Sunlight, from the right, emphasizes the color of their coats of reddish brown, white and black. Overhead is a sombre sky with clouds gathered for a summer shower.

Signed at the lower left, and dated '99.

Purchased direct from the artist, New York, 1900. 


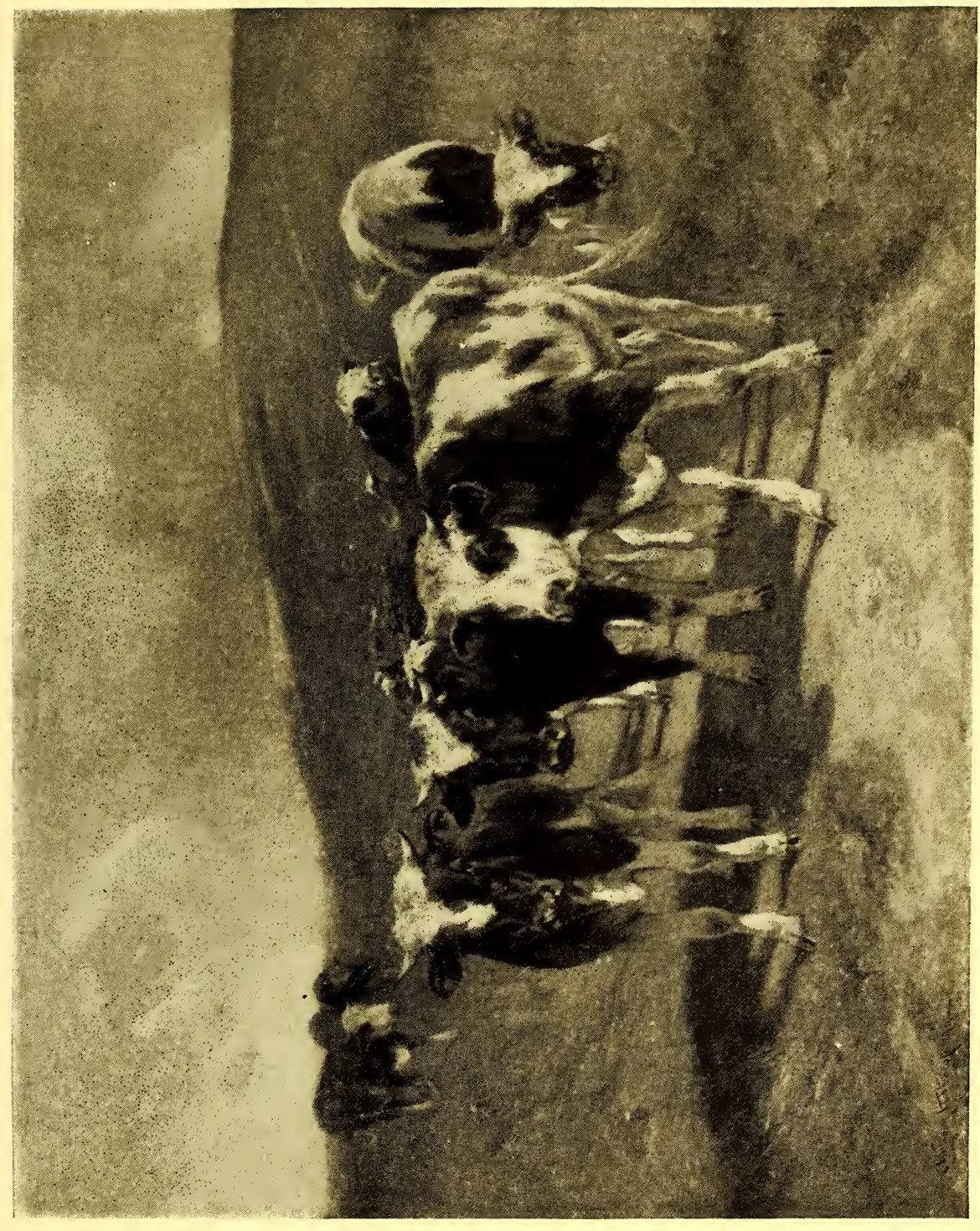


No. 53

\section{WILL HOWE FOO'TE, A.N.A.}

American: $18 \%$ -

\section{THE OLD BRIDGE}

Height, 26 inches; length, 32 inches

A PICTURE of serene general aspect showing an arching bridge, on high piers, spanning the waters of a placid river. The color scheme consists of quiet, sympathetic grays with a darker accent given by the reflection of the bridge in the water. From the left foreground, on the bank, two or three slender trees raise their trunks and branches to the top of the canvas.

Signed at the lower left, and dated 1902.

Purchased at the Society of American Artists, New York, 1902. 


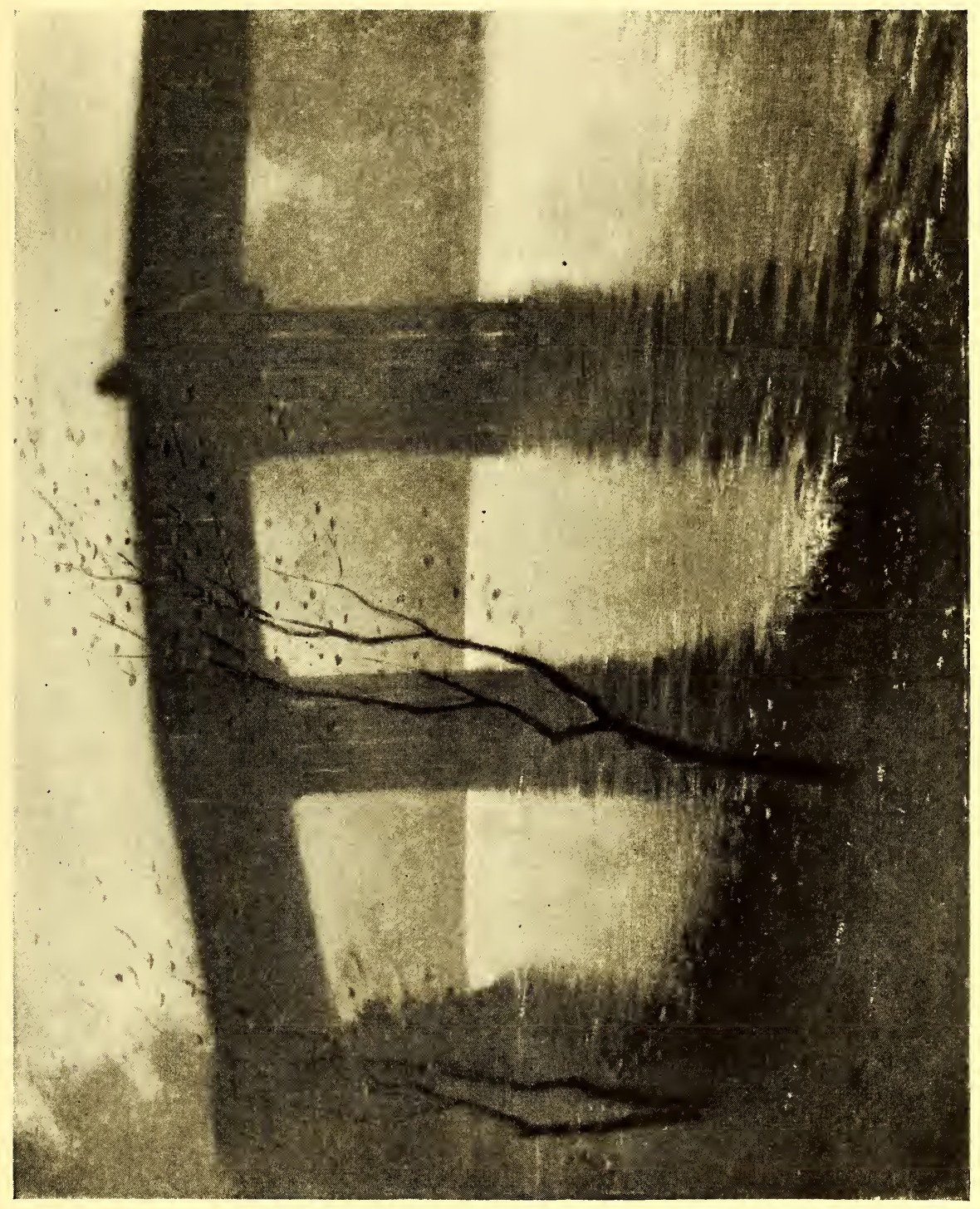


No. 54

\section{REY NOLDS BEAL, N.A.}

American : $186 \%$

\section{OFF NEW LONDON}

Height, 24 inches; length, 36 inches

A yawL is seen scudding along in the sea, in the foreground, and there is another sail in the offing. Beyond is a line of hills, dimly blue, marking the shore. Overhead is a high sky of cumulus clouds, gray and tinted white, with spaces of blue.

Signed at the lower right, and dated 1902. 


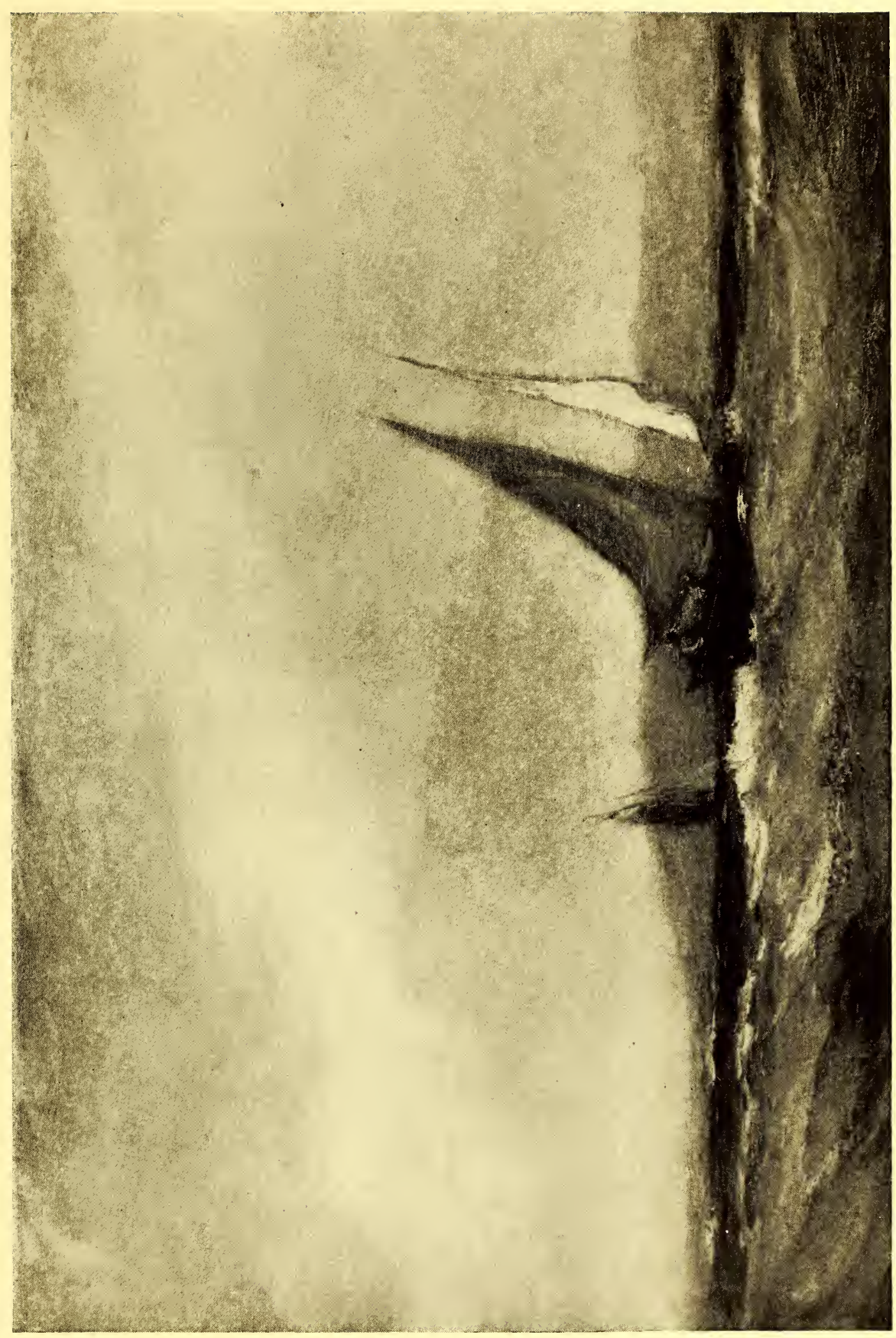


No. 55

\section{HUGH BOLTON JONES, N.A.}

American: 1848-

NEAR ORANGE, NEW JERSEY

Height, 24 inches; length, 36 inches

A PLACID stream flows through the foreground, on the right, with green pastures on either side. Across the middle distance is a belt of trees in late summer foliage showing here and there notes of yellow or brown. Above is a sky of pale blue with broken clouds of white.

Signed at the lower left.

Thomas B. Clarke Collection, 1899, Catalogue No. $5 \%$. 


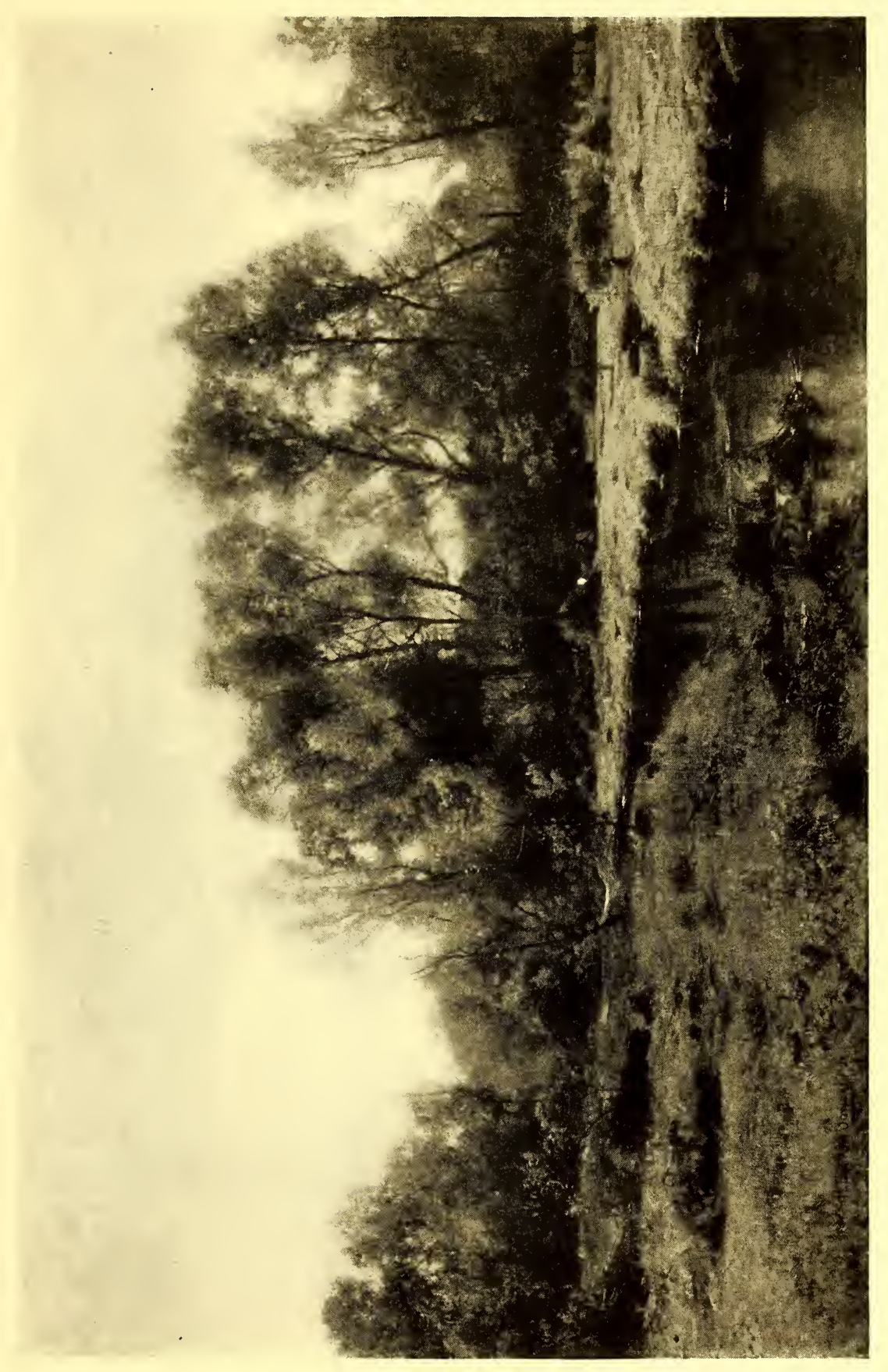


No. 56

\section{WILLIAM SARTAIN, A.NA.}

American : $1843-$

\section{AN ARAB SCHOOL IN ALGIERS}

Height, 26 inches; length, 36 inches

In an alcove of an Oriental apartment with pillars and arches appears the seated form of an Arab teacher, gowned in black and wearing a white turban. Seated on the floor before him, with backs to the spectator, or standing nearby against the walls and pillars, are several youths, in costumes of blue, red, yellow, brown and white and fezzes of white, red or blue. This group of figures is depicted in the somewhat tenebrous lighting common to many Oriental interiors.

Signed at the lower right.

Purchased from William Macbeth, New York, 1904. 


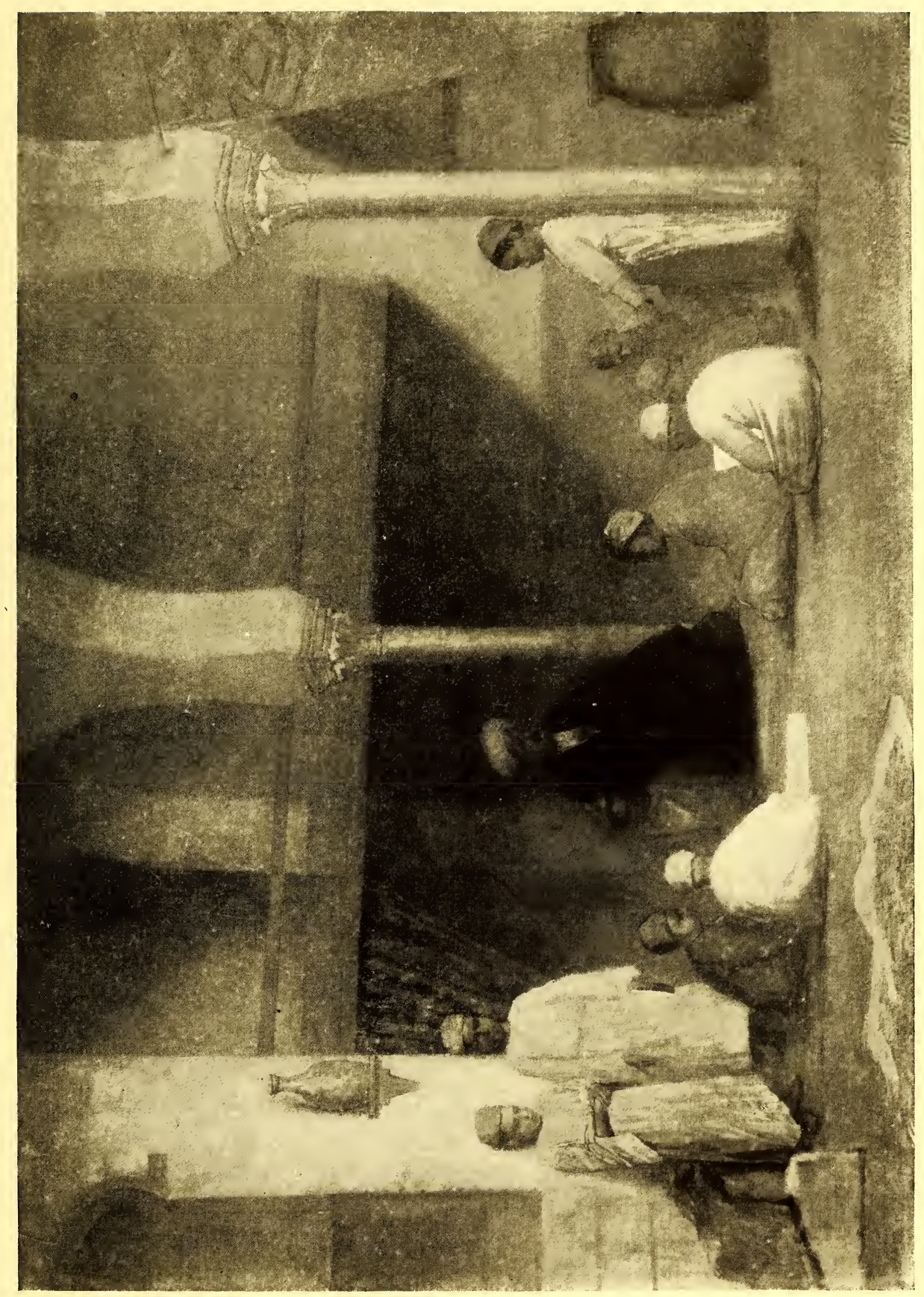


No. $5 \pi$

\section{THOMAS MORAN, N.A.}

Americhn : 1837 -

\section{THE MOUNTAIN OF LOADSTONE}

\section{(Arabian Nights)}

Height, 20 inches; length, 30 inches

A Marine with the waves of the green ocean dashing against a rocky shore, on the right, and a mountain peak rising high above. The sun is depicted setting in a sky of red, yellow and other strong tints.

Signed at the lower left, and dated 1898.

Purchased at the National Academy of Design, New York, 1899. 


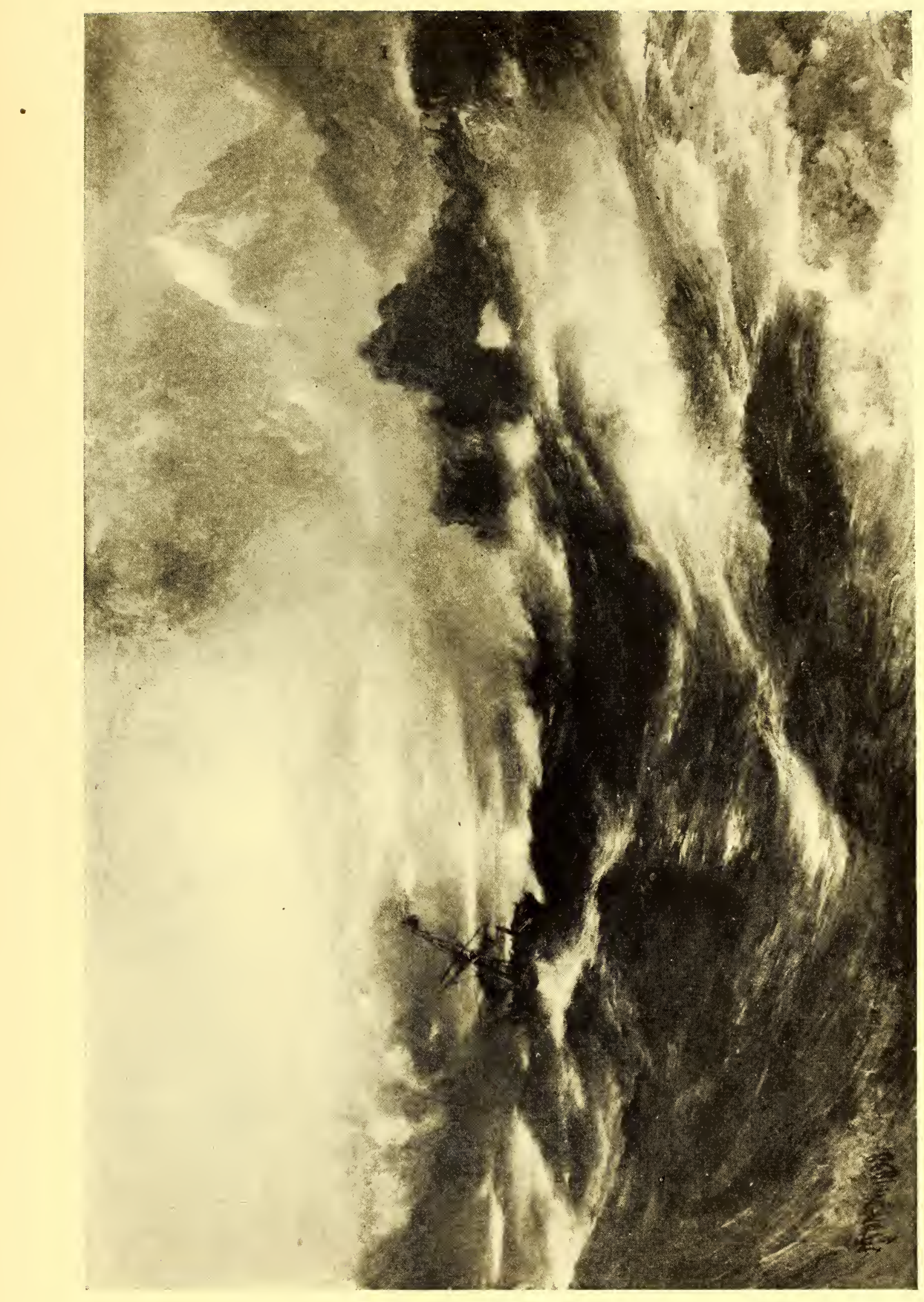




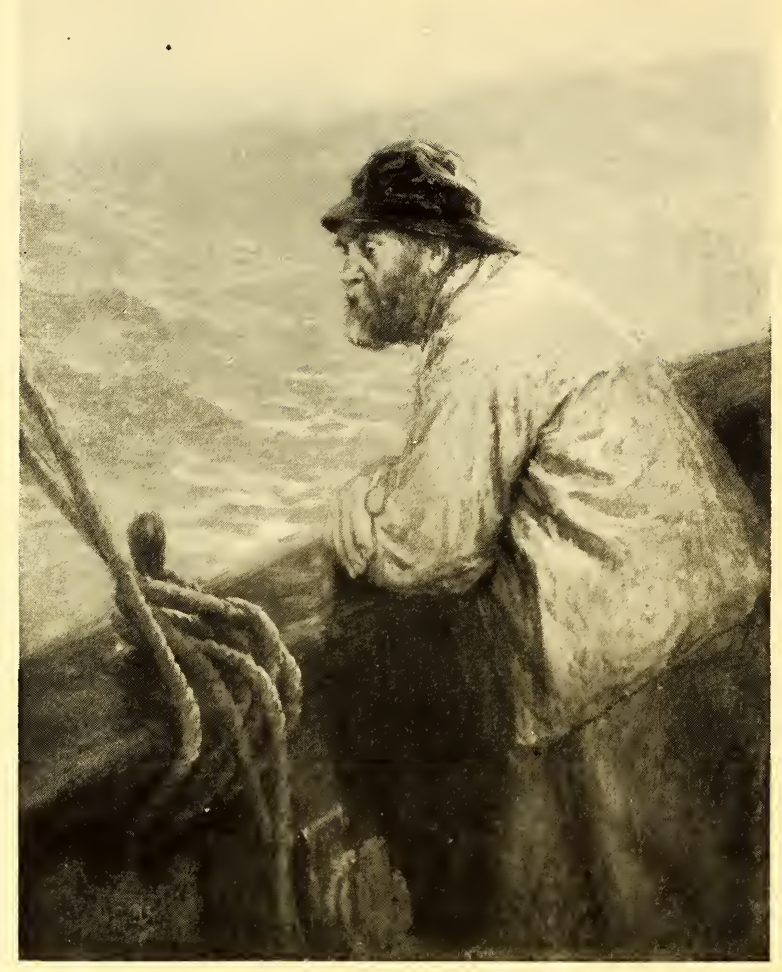

No. 58

\section{EDWARD H. POT'THAST, N.A.}

Americhan: $185 \%$ -

\section{OFF THE GRAND BANKS}

Water Color: Height, 30 inches; width, 22 inches

A BEARDED sailor-man, with sou'wester and oilskins, is here depicted leaning on the gunwale of his vessel, the upper part of the figure being relieved against the high rolling masses of water which, by their shape and movement, truthfully represent the locality of the subject. From the sky above, but from outside of the picture, falls a gleam of pale sunlight in the trough of the great waves.

Signed at the lower left.

Purchased at the American Water Color Society, Nere York, 1899, Catalogue No. 272. 


\title{
SAMUEL COLMAN, N.A.
}

\author{
American : 1832
}

\section{SAW MILL RIVER}

\section{Height, 16 inches; length, 30 inches}

A Landscape of peaceful aspect, in which the principal elements are a placid stream traversing the foreground, trees with spreading branches in the middle portion of the picture, and a wooded hillside bordering the valley. On the banks of the stream are cattle coming to drink and one or two figures. Above is a summer sky with masses of white clouds and here and there a space of blue.

Signed at the lower left, and dated 1868. Purchased from John Snedecor's Sons, New York, 1899.

No. 60

\section{ELLIO'T'T DAINGERFIELD, N.A.} American：1859-

\section{THE DRAMA OF THE MOUNTAIN TOPS}

Height, 30 inches; length, 36 inches

In the immediate foreground, which represents the point of view for the picture, is a space of ground with rocks. Immediately beyond masses of white mist are seen, from which, in the middle of the composition, arise the dark peaks of a mountain range. Above, in the right upper half of the canvas, is a sky of blue with white clouds which is rapidly being shut out from view by a heavy shower, represented as descending straight from the heavens on the upper left of the picture.

Signed at the lower right.

Purchased direct from the artist, New York, 1906. 


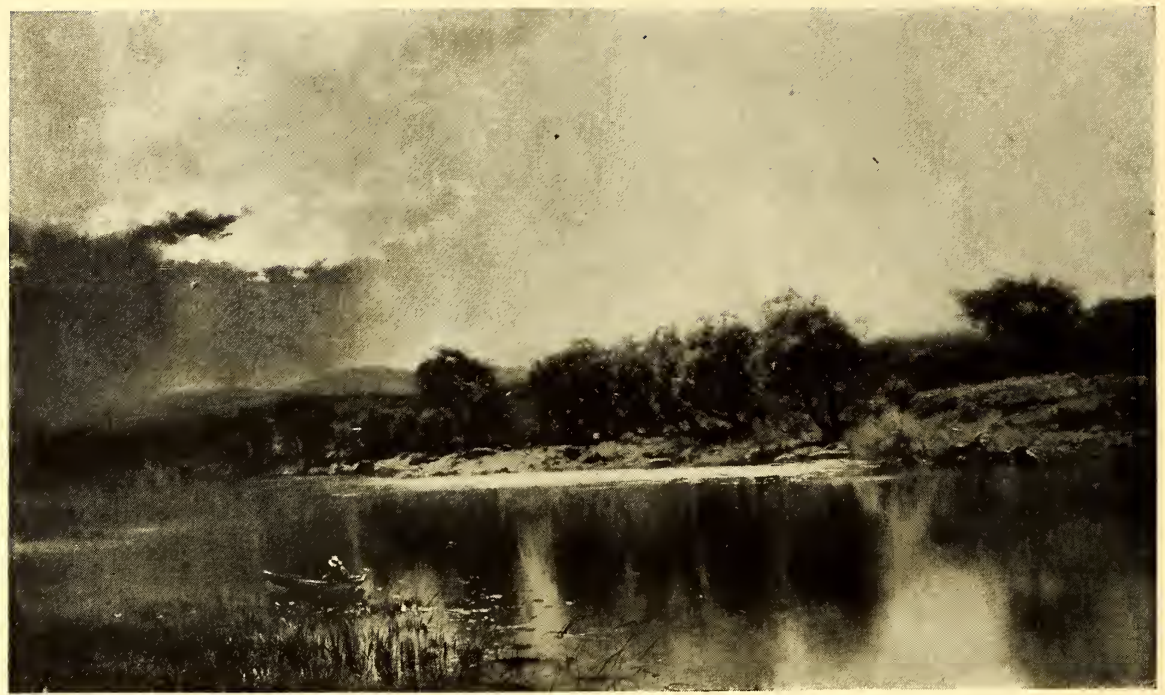

No. 61

\section{AR'THUR PAR'TON, N.A.}

Americhin: 1842-1914

\section{THE PASSING SHOWER}

Height, 18 inches; length, 301/4 inches

A Richly-toned landscape in which the foreground is occupied by the smooth waters of a river. On the farther bank, in the middle distance, are hillocks and trees, while on the left beyond is a distant mountain range. 'The summer sky, with spaces of blue in the upper portion on the right and cumulus clouds below, shows on the left a mass of dark clouds, where a shower is passing over the mountain range. In the immediate foreground, on the left, are a skiff and figure.

Signed at the lower left.

Thomas B. Clarlie Collection, New York, 1899, Catalogue No. 283. 


\title{
EDWARI) H. PO'T'THAS'T, N.A.
}

\author{
American : 185\%-
}

\section{THE VILLAGE CARPENTER}

Height, 30 inches; length, 20 inches

THE carpenter, in his shirt-sleeves and blue working apron, is seen standing at his bench, working with chisel and hammer. Through the panes of a window and an open door, on the right, the view from his shop discloses a door-yard with the red brick wall of a house, vines and flowers. 'The values are well maintained in this interesting example of American genre painting and the effects of light are realistically rendered.

Signed at the lower left.

Purchased at the National Academy of Design, New Yorl, 1899, Catalogue No. 29 or 35.

No. 63

\section{FREDERICK W. KOST, N.A.}

American: 1861-

\section{THE DRIFTWOOD GATHERER}

\section{Height, 22 inches; length, 28 inches}

Is the foreground, on a sandy hillock partly covered with herbage and overlooking the sea, a man is piling up pieces of driftwood which he has gathered along shore. The expanse of water in the middle portion of the picture and the gray sky above form a sympathetic harmony with the brownish-pink of the sand dune and its dull green herbage, the whole making a picture of unified effect. 


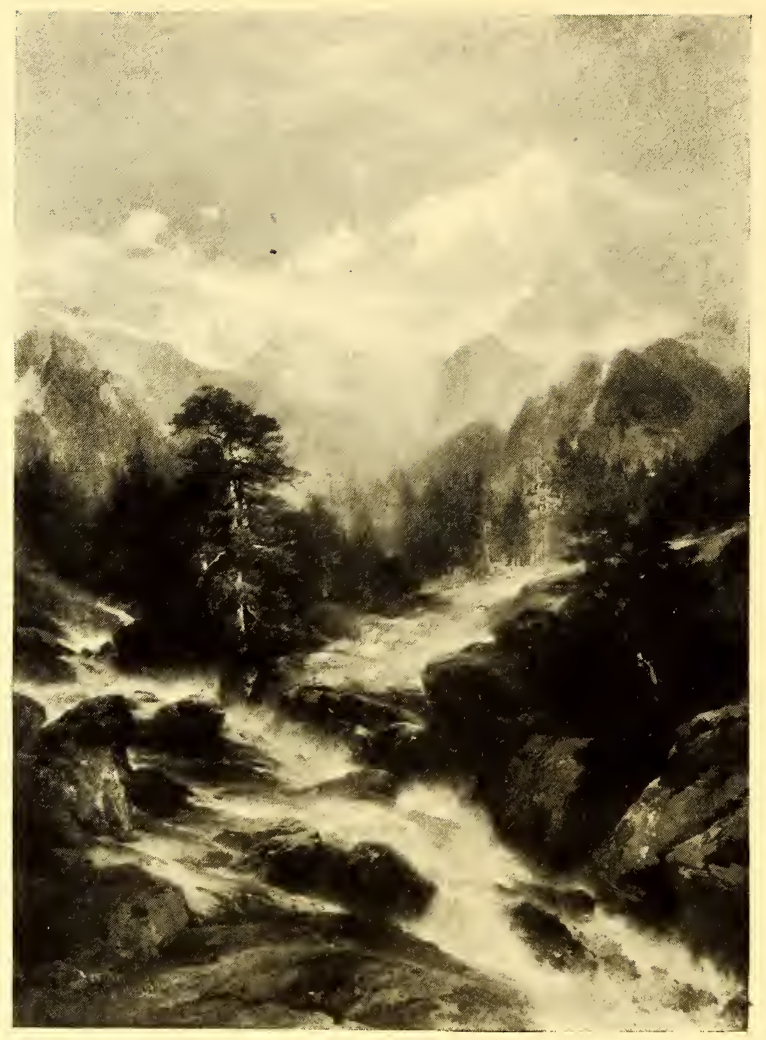

No. 64

\section{THOMAS MORAN, N.A.}

American :

\section{IN THE TETON RANGE-IDAHO}

\section{Height, 42 inches; width, 30 inches}

A dramatic composition with a stream rushing swiftly downward over rocks in the foreground, and the range of mountains filling the upper part of the canvas with peaks covered with snow. A gleam of sunlight illumines a portion of the middle distance, where a pine tree grows at the side of the stream and sunshine also falls on the mountain tops. Over all, a space of blue sky with gray and white clouds.

Signed at the lower left, and dated 1899.

Purchased at the National Academy of Design, New York, 1899. 
No. 65

\section{LOUIS PAUL DESSAR, N.A.}

American: $186 \%$

\section{NOCTURNE-MOONRISE WITH SHEEP}

Height, 18 inches; length, 36 inches

IN this pastoral scene a flock of sheep is depicted in the middle part of the composition, with the shepherd standing nearby, in the right foreground. On the left is a slightly rocky eminence, and overhead an evening sky with principal notes of blue and yellow. The moon, just above the horizon, already sheds sufficient light to accent the backs of the woolly flock.

Signed at the lower right, and dated 1906.

Purchased direct from the artist, 1907.

No. 66

\section{HENRY WARD RANGER, N.A.}

American : $1858-1916$

\section{CLOUD AND SEA-PORTO RICO}

\section{Height, 36 inches; width, 28 inches}

The blue-green expanse of the sea occupies the lower part of the canvas, and above a low horizon rises a high sky, with a great white cloud in the central portion. Other smaller clouds, above and below, are seen, contrasting with open spaces of tempered blue.

Signed at the lower left, and dated 1905.

Purchased direct from the artist, New York, 1906. 
No. 67

\section{W. S. BUCKLIN}

American : $1851-$

\section{EARLY SPRING MORNING}

Water Color: Height, 30 inches; length, 40 inches

A Misty landscape of springtime, depicted in pale tints. From a foreground, in which are a few slender trees, the eye passes over a stretch of country to a hillside, dimly seen beyond and showing a shimmering haze of pale blue. Above is a sky with clouds accented with white in the upper portions of their masses.

Signed at the lower right, and dated '99. 


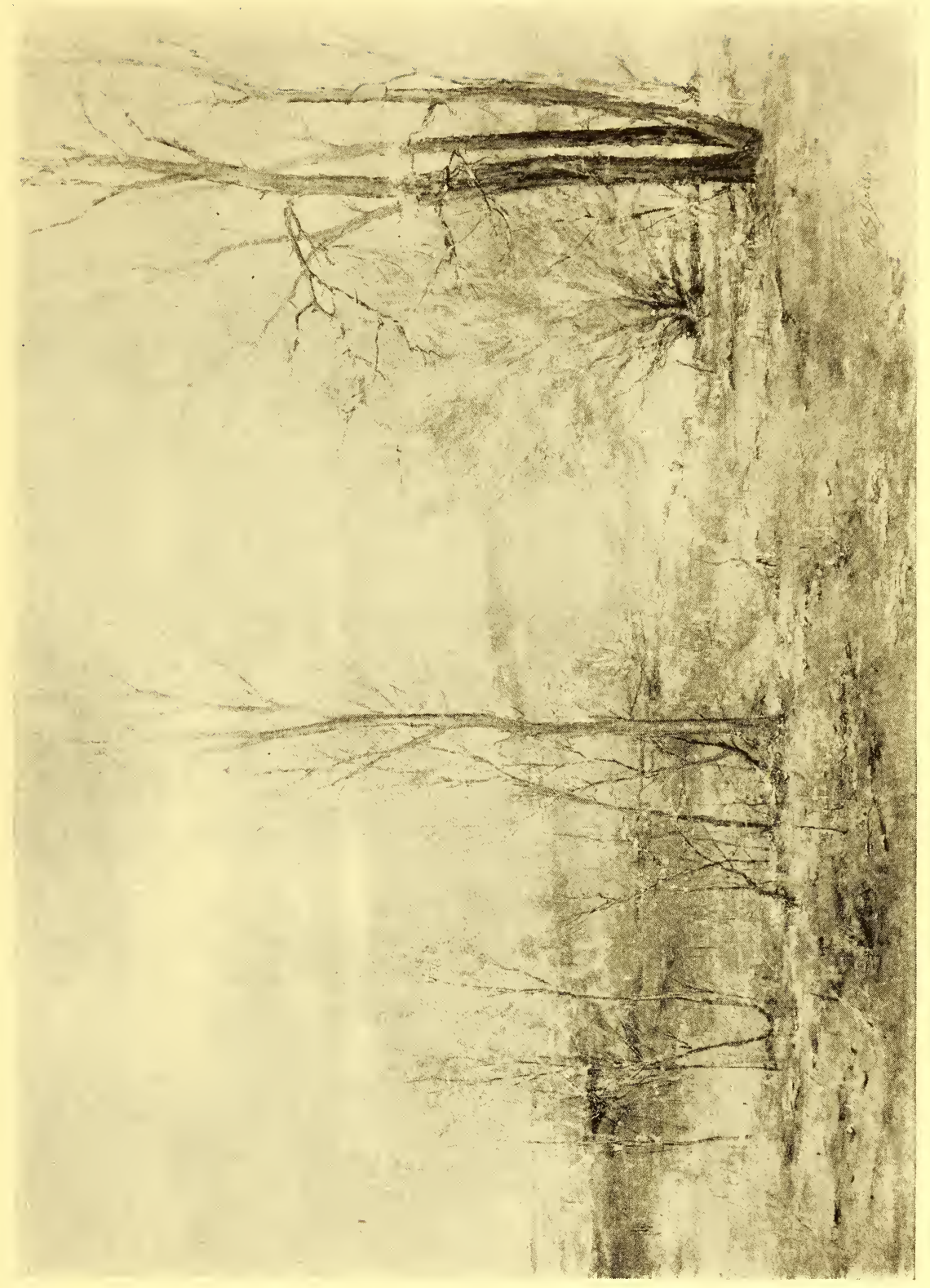


No. 68

\section{HENRY GOLDEN DEARTH, N.A.}

American : 1864-

\section{THROUGH THE BEECHES}

Height, 35 inches; width, 20 inches

A company of people, ladies and escorts, all clad in brilliant costumes of many different hues, are seen descending a steep grassy slope lined on either side by beech trees in red, crimson and other tints of autumn foliage. In the upper part of the composition is a glimpse of blue sky with white clouds. The whole constitutes a fantasy in striking color effects.

Signed at the lower right.

Purchased direct from the artist, New York, 1910.

No. 69

HENRY WARD RANGER, N.A.

American: 1858-1916

\section{PEACEFUL MOONLIGHT REIGNS}

Height, 36 inches; reidth, 28 inches

A Bove a rugged landscape there is a high expanse of evening sky, in which a full moon is seen in the upper center. 'The landscape is bathed in its light and a few stars twinkle in the canopy.

Signed at the lower left, and dated 1904.

Purchased direct from the artist, New Iork, 1905. 
No. 70

\title{
PAUL DOUGHERTY, N.A.
}

\author{
AMERICAN : $187 \%$
}

\section{THE INCOMING TIDE}

Height, 26 inches; length, 36 inches

A composition of great rock masses gleaming with tints of tawny red where they are lit by an afternoon sun and in contrast to strong shadows. In the foreground the sea is lapping in among them as the tide rises, the greens and whites of its waters making a telling foil for the glowing color of the rocks. At the top of the canvas, seen above the cliffs, are white clouds, tinged with pink, in a sky of qualified blue.

Signed at the lower right, and dated $190 \%$.

Purchased direct from the artist, New York, $190 \%$.

No. 71

\section{LOUIS PAUL DESSAR, N.A.}

American : 1867-

\section{THE RETURN-EVENING}

Height, 18 inches; length, 36 inches

THE center of the picture is occupied by a loaded cart, drawn by a team of white-faced oxen, approaching the spectator. Walking beside the cart is the driver, whose jacket provides a valuable note of subdued blue. Above a low horizon is an evening sky, with the rising moon indicated on the right. The general color scheme is cast in grays and browns.

Signed at the lower right, and dated 1906-'09.

Purchased direct from the artist, New York. 
No. 72

\section{GEORGE HITCHCOCK, A.N.A.}

Aimerican : $1850-1913$

THE DUNES, HOLLAND

Height, 271/2 inches; length, 46 inches

Axrm the Holland dunes, with stretches of white sand, scattered grass and herbage, sheep are seen wandering as they pasture. Just over the most distant of the dunes, on the left, is a narrow strip of the sea, and above is a sky of pale tempered blue with a few white clouds. The picture is painted in light tones with prevailing notes of bluish-green and various grays, and a touch of yellow is given by blossoms on one of the bushes in the foreground.

Signed at the lower right, and dated 1892.

Boussod, Valadon Collection, New York, 1902, Catalogue No. 81. 


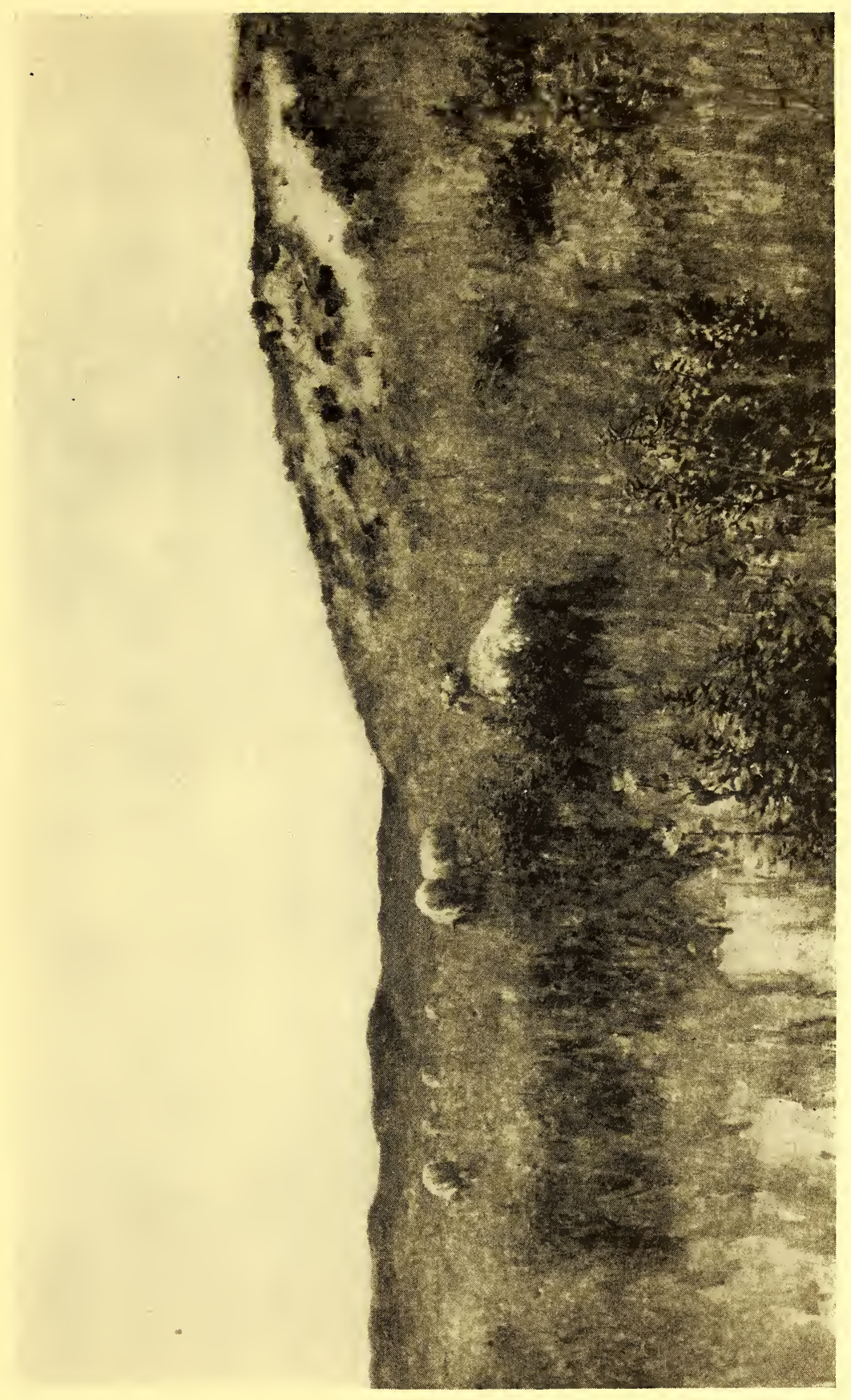


No. 73

\section{WALTER ELMER SCHOFIELD, N.A.}

American: $186 \%$ -

\section{A BREEZY DAY, EARLY AUTUMN \\ Height, 30 inches; length, 37 inches}

THe composition shows a grove of trees, on a bank covered with tangled herbage, and a whitish-gray sky beyond. The color notes comprise qualified greens, browns and grays.

Signed at the lower right.

From the Pennsylvania Academy of Fine Arts, 1903, Catalogue No. $10 \%$. 


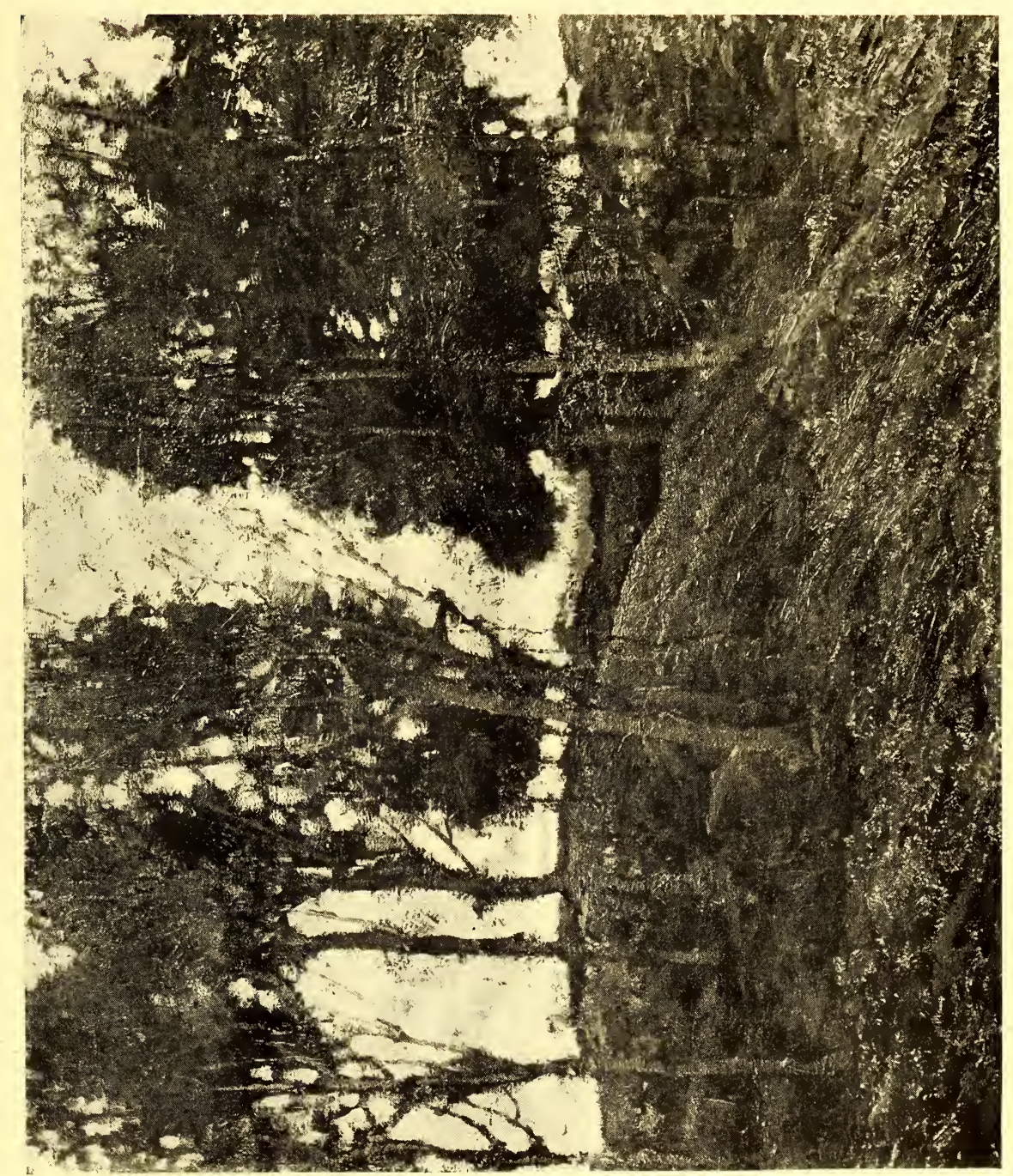


No. 74

\section{PAUL DOUGHERTY, N.A.}

American : $18 \% 7$ -

\section{EASTERLY STORM-BOAR'S HEAD}

Height, 26 inches; length, 36 inches

THE middle portion of the picture is occupied by the ocean with waves breaking in surf and foam against a rocky shore. The tops of the cliffs fill the foreground, and the sky above is heavily clouded with dark gray.

Signed at the lower right, and dated 1905.

Purchased direct from the artist, New York, 1906. 


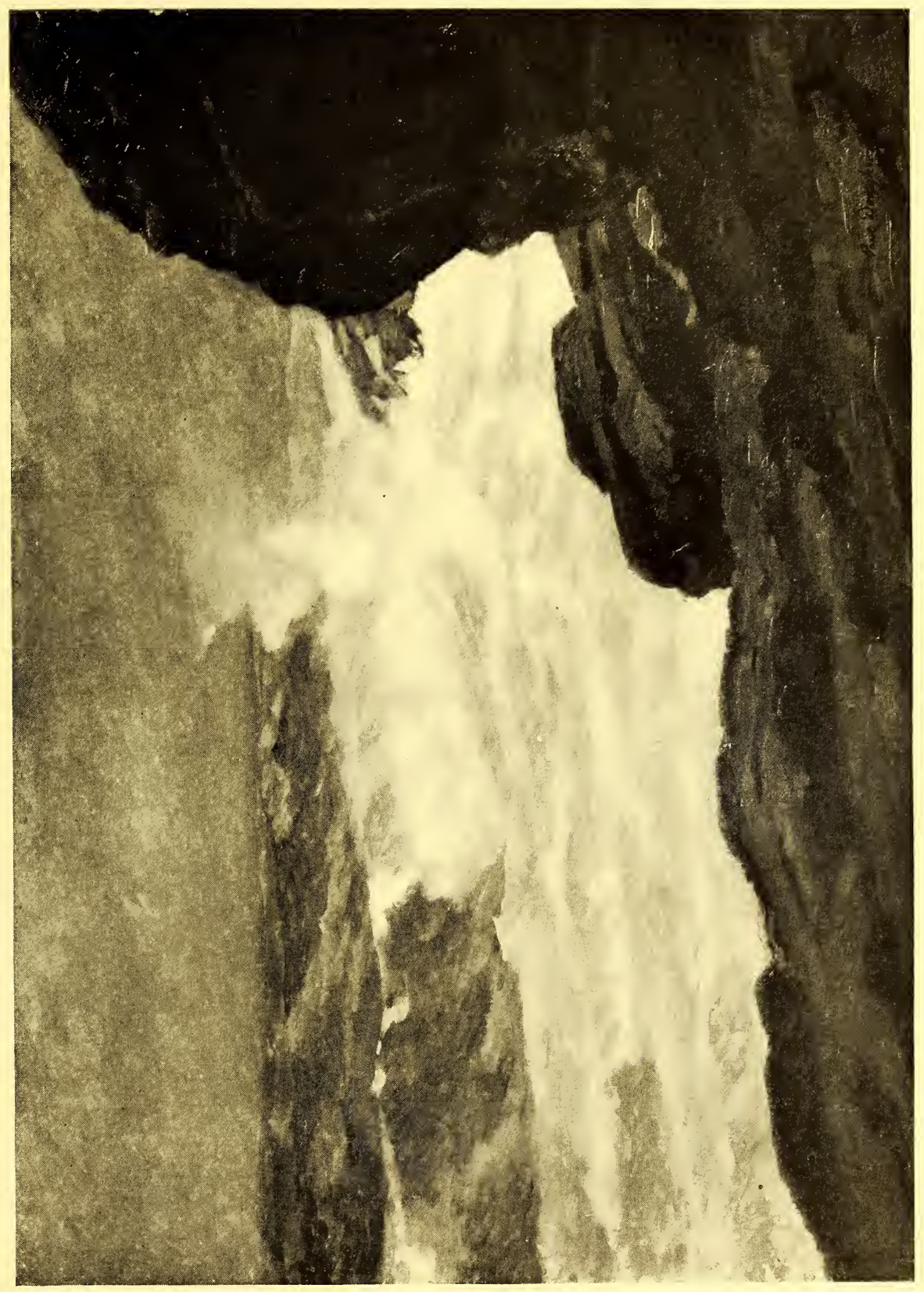


No. 75

\section{PAUL DOUGHERTY, N.A.}

American : $187 \%$ -

\section{MID-ISLAND GORGE}

Height, 20 inches; length, 30 inches

A Low-Toxem landscape depicting a wide stretch of undulating country, with a ravine running through it in the middle distance. On the farther side of the ravine, some rocks catch the light from the sky, striking a higher note of color amid dark greens and browns. Beyond is a troubled sky of gray and white clouds.

Signed at the lower left.

Purchased direct from the artist, New York, $190 \%$.

No. 76

HENRY WARD RANGER, N.A.

American: $1858-1916$

\section{A CLASSIC-MASON'S ISLAND}

\section{Height, 28 inches; length, 36 inches}

NEAR the center of the composition is a great oak tree in autumn foliage, growing at the edge of a forest, which appears on the left; in the foreground, on the right, a pool. Beyond is a prospect of level country, with a line of blue hills at the horizon, while through the open spaces in the foliage is seen a blue sky gradating to light gray below. An excellent effect is obtained by the arrangement of light and dark, and rich color notes.

Signed at the lower left, and dated 1903.

Purchased direct from the artist, New York, 1905. 


\section{ELLIO'T'T DAINGERFIELD, N.A. \\ American : 1859- \\ SUNSET-MISTS AND SHADOWS}

Height, 30 inches; length, 36 inches

The point of view is from rising ground where are rocks and trees, including a storm-torn pine, overlooking a wide valley. Mist is rising over a distant range of hills and, above, the red disk of the sun is seen through a mist of gray. The upper portion of the sky is illumined with touches of orange.

Signed at the lower center.

Purchased direct from the artist, New York, 1906.

No. 78

\section{CHARLES ROLLO PETERS}

Anerican : 1862

\section{SAN JUAN MISSION}

Height, 36 inches; width, 30 inches

Av effect of moonlight. The white façade of the Mission fills most of the canvas, and a great arched doorway and an open window, above, as well as the cornice of the building, furnish masses of dark. The moonlight glow on the wall is further enhanced in effect by some dark masses of foliage and heavy shadows in the lower part of the picture. Dimly seen are the figures of a woman and child about to enter the Mission.

Signed at the lower right, and dated $\mathrm{S}_{\mathrm{AN}} \mathrm{JUAN}_{\mathrm{UAN}} 1891$. 
No. 79

\title{
ELLIO'T'T DAINGERFIELD, N.A.
}

\author{
American: $1859-$
}

\section{DEAD TREES}

Height, 30 inches; length, 36 inches

A Landescape painted in a fairly light key, showing a road leading from the foreground into the right middle distance, with a covered wagon drawn by oxen. On either side of the road are a few dead slender trees. The middle portion of the canvas shows an expanse of pale gray, which seems to indicate a mountain side seen at a distance through the mist, and above is a sky of broken gray clouds with a few dashes of blue.

Signed at the lower left, and dated 1906.

Purchased direct from the artist, New York, $190 \%$. 


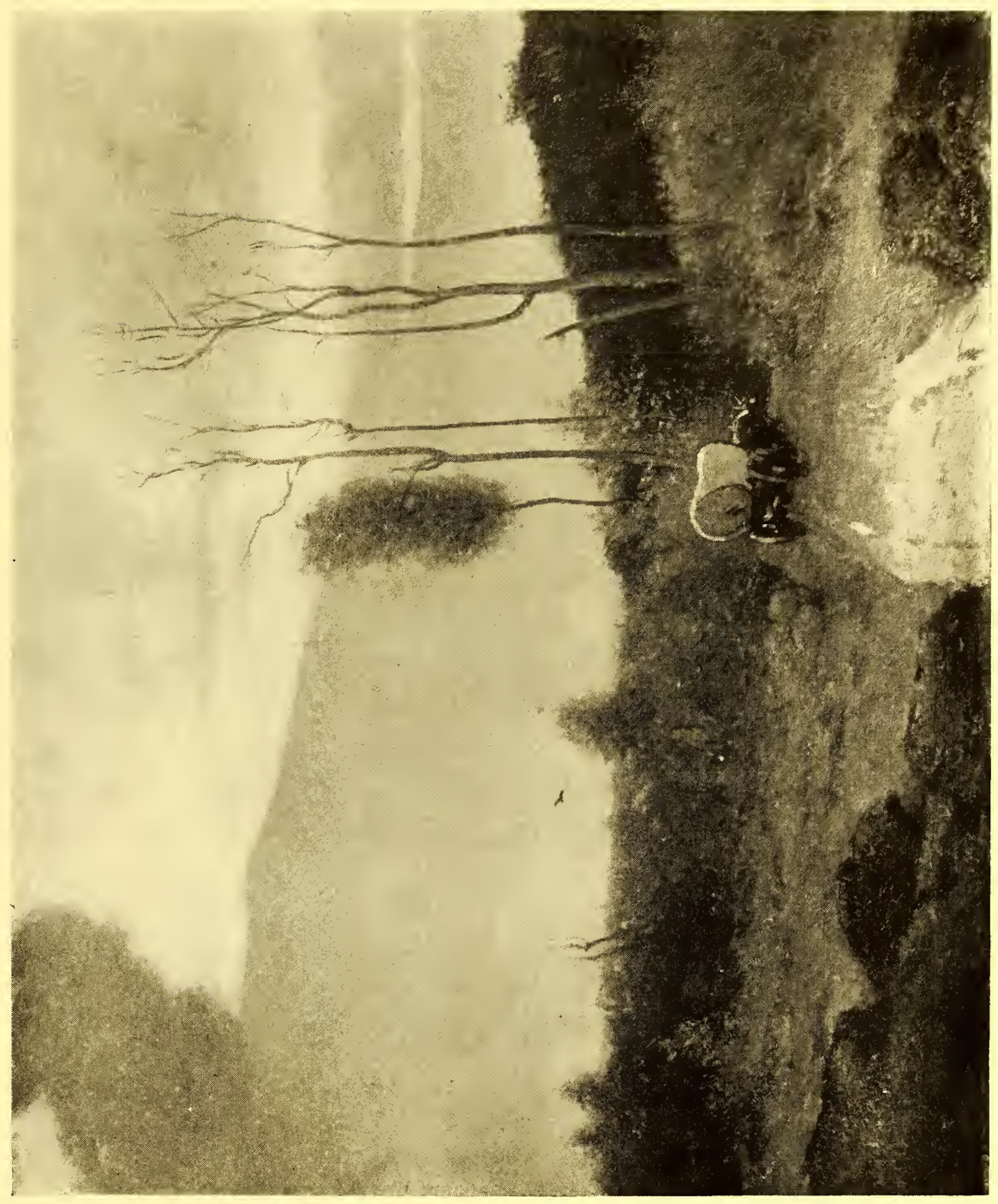


No. 80

\section{LEONARD OCH'TMAN, N.A.}

American: 1854-

\section{AUTUMN TWILIGHT}

Height, 52 inches; width, 36 inches

A handsome canvas, in which the color scheme is composed of autumn tints of the russet foliage of the trees, bordering a pasture and hillside of contrasting dull greens. Two cows are seen in the middle distance. Through the foliage of the trees, which reach up to the top of the picture, appears a luminous evening sky.

Signed at the lower left, and dated 1899.

Purchased at the Pennsylvania Academy of Fine Arts, 1900, Catalogue No. 50. 


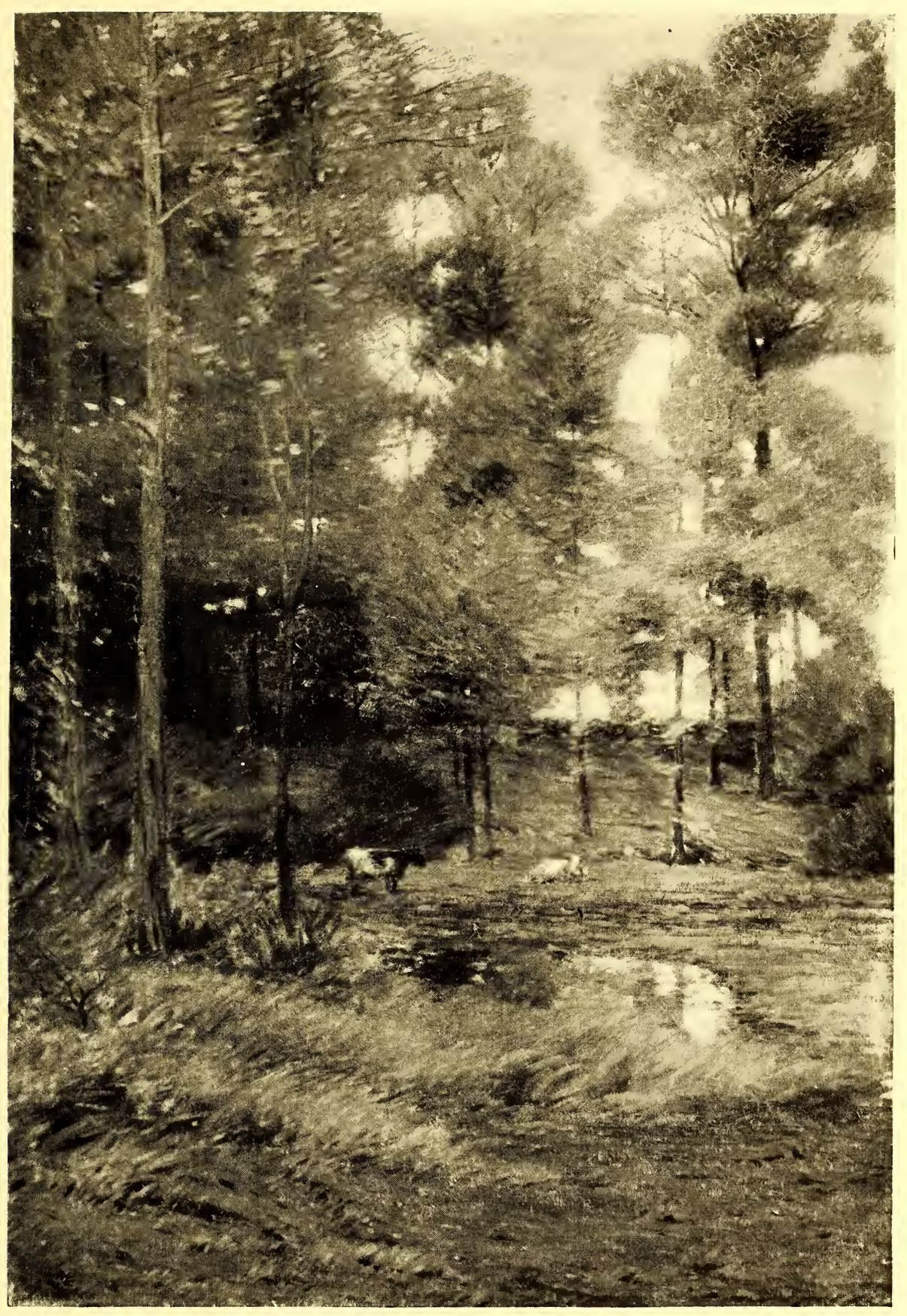


No. 81

\section{BEN FOS'TER, N.A.}

American : 1852-

\section{A MURKY EVENING}

\section{Height, 36 inches; length, 42 inches}

A Moonlight effect, with the moon in a landscape, depicted in tints of gray. The lower half of the picture shows a sloping hillside, with a road, along which a man is driving some sheep. A grove of trees is seen on the left.

Signed at the lower left.

Purchased direct from the artist, New York, 1904.

No. 82

\section{PAUL DOUGHERTY, N.A.}

American : $18 \%$ -

\section{CORNWALL ROCKS}

\section{Height, 26 inches; length, 36 inches}

Great masses of jagged rocks are seen on the shore at the right, illumined by sunlight in tints of varied grays; also, many rocky spaces of ground partly grass-covered. The sea, with green and violet tints, fills the left side of the picture and breaks in white foam against the rocks. The sky is composed of diversified grays.

Signed at the lower right, and dated 1909.

Purchased direct from the artist, New York, 1906. 
No. 83

\section{HENRY BAYLEY SNELI, N.A.}

Americhn : 1858-

\section{TWILIGHT AT SEA}

Water Color: Height, 441/2 inches; width, 341/2 inches

A PICTURE of a large square-rigged vessel, with white hull and all sails set, is seen moving slowly forward to the spectator, in the smooth gray-blue waters of the sea. The mass of the vessel rises up majestically before a sky of tempered blue, and a rosy light on the port gunwale makes a telling note of warm effulgence amid the shadowy tints of cool and quiet twilight blues.

Signed at the lower right.

Purchased at the American Water Color Society, New York, 1899, Catalogue No. 239. 


\section{SECOND AND LAST EVENING'S SALE}

THURSDAY, FEBRUARY 15, 1917

\section{IN THE GRAND BALLROOM OF THE PLAZA}

Fifth Avenue, 58th to 59th Street

BEGINNING AT 8.15 O'CLOCK

Nos. 84 to 166 , inclusive 
No. 84

\section{RALPH ALBER'T BLAKELOCK, N.A.}

American : 1847 -

\section{INDIAN HUNTER}

Height, 8 inches; width, 6 inches

Av Indian is seen on the left, drawing his bow as he is about to shoot at a deer, which is bounding away on the right of the picture. The landscape composition shows trees on the left and a bit of warm tinted in the upper right of the picture.

Signed at the lower right.

Frederick S. Gibbs Collection, New York, 1904, Catalogue No. 108.

No. 85

RALPH ALBER'T BLAKELOCK, N.A. American: 1847-

\section{THE WAYFARERS}

Height, 8 inches; width, 6 inches

In a landscape setting, with the foliage of trees on either side framing in a vista of hills and sky, are two small figures approaching in the foreground. In their costumes are notes of red and blue.

Signed at the lower right.

Frederick S. Gibbs Collection, New York, 1904, Catalogue No. 107. 


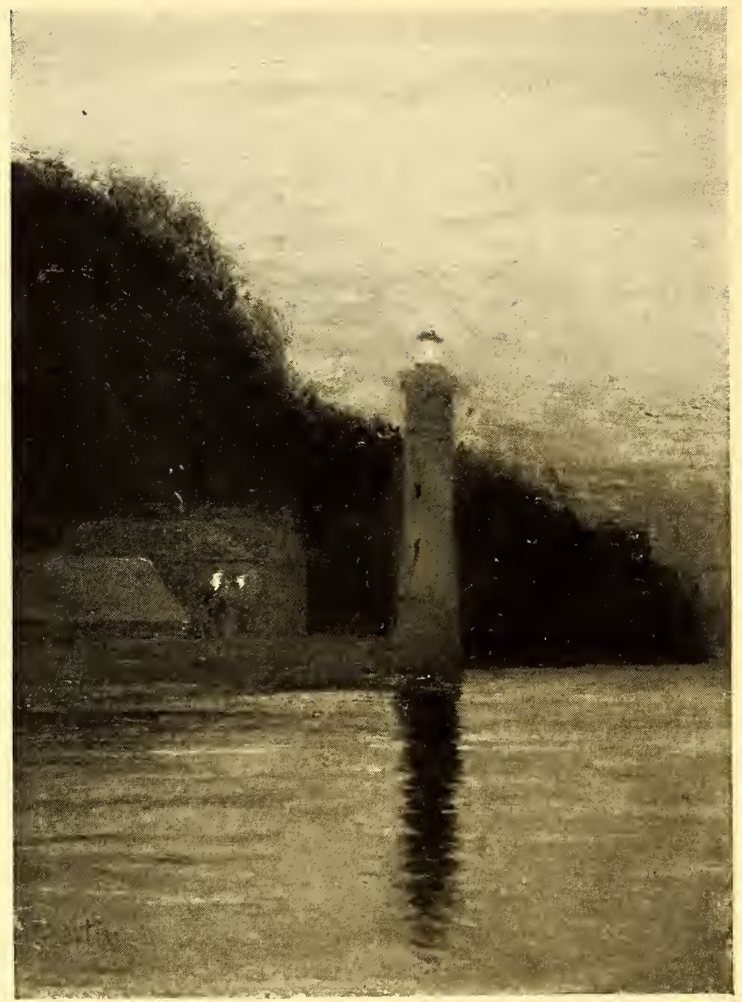

No. 86

\section{HOMER D. MAR'TIN, N.A.}

Anericax : $1836-1897$

\section{LIGHTHOUSE-HONFLEUR}

Panel: Height, 11 inches; width, 8 inches

This little picture, painted in a symphony of tender grays, shows a lighthouse tower with the light shining out, and two windows in the house adjoining showing glints of light also. Back of the buildings is a steep shore, and the smooth water of the foreground, slightly rippling, reflects the gray sky and the lighthouse.

Signed at the lower left.

From William Macbeth, February, 190\%, who purchased the painting from Mr. Frank Lethbridge. Letter to Mr. Macbeth from Lethbridge regarding the painting will be presented to the purchaser. 


\title{
No. 87 \\ J. FRANCIS MURPHY, N.A.
}

Anerican: 1853-

\section{THE WOODS}

\author{
Height, 8 inches; length, 12 inches
}

A LANDSCAPE showing a harmony of sober autumn tints, the composition consisting of lowlands with groups of trees on the right; a glimpse of distance and sky at the left.

Signed at the lower right, and dated '89.

T. Kirkpatrick Collection, New York, 1900.

No. 88

\section{J. FRANCIS MURPHY, N.A.}

\author{
Anerican : 1853 -
}

\section{SUNSET}

Height, 8 inches; length, 10 inches

A group of trees near the center of the picture, in the middle distance, silhouetted against a glowing evening sky; a line of hills, a barn on the left, and a level foreground with a bit of water, are the elements in this little landscape.

Signed at the lower left.

Purchased from S. P. Azery, Jr., New York, 1900. 


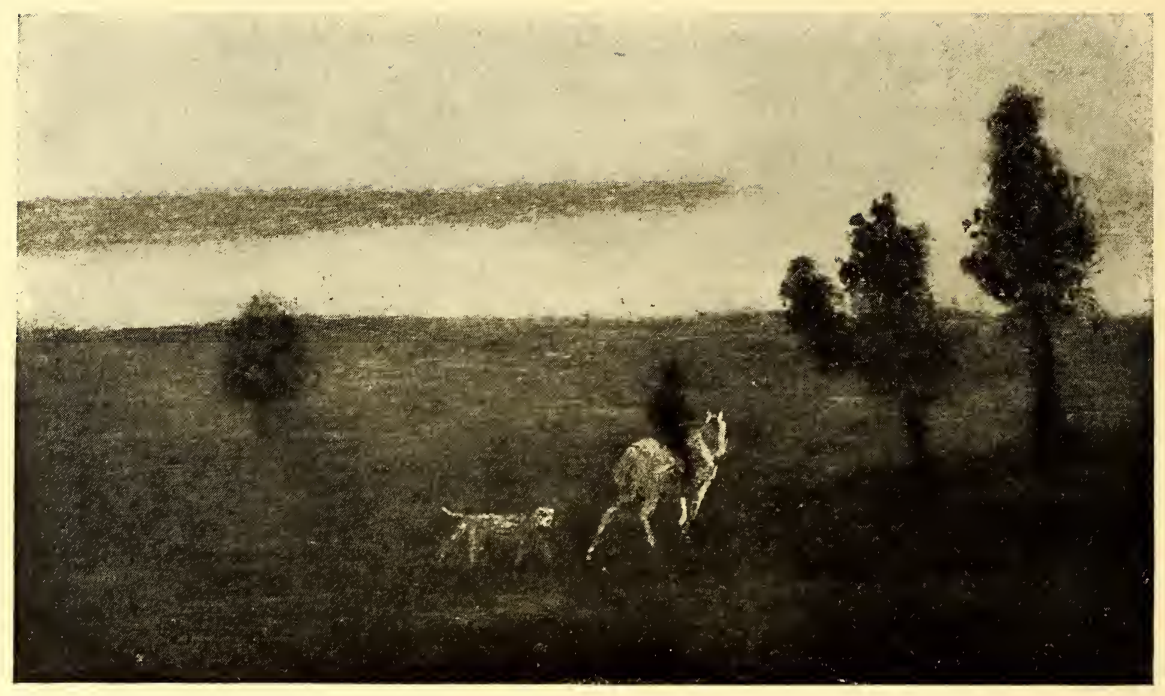

No. 89

\section{ALBERT PINKHAM RYDER, N.A.}

American: 184\%-

\section{TWILIGHT}

Panel: Height, 5 inches; length, 81/2 inches

A man riding a white horse, with a dog at his heels, is seen in the foreground, crossing a plain; two small trees are on the right and a third in the left middle distance. Above the low horizon is an evening sky with a strip of gray cloud.

Purchased from William Macbeth, New York, 1902. 


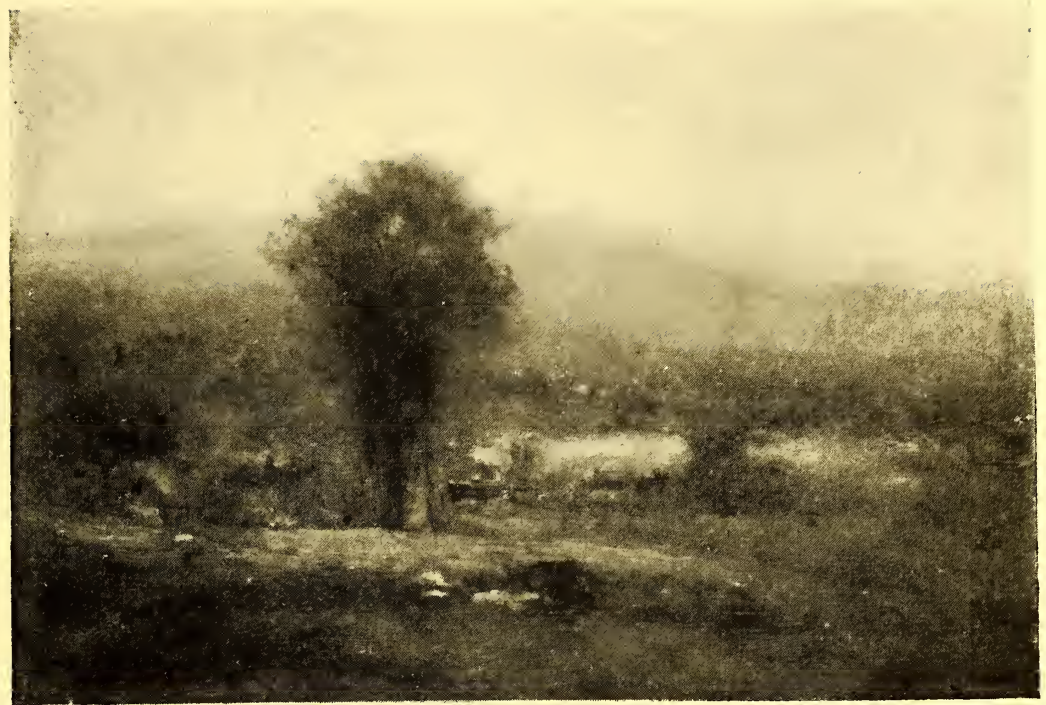

No. 90

\section{GEORGE IN N ESS, N.A.}

American : 1825--1894

\section{LEEDS, NEW YORK}

Millboard: Height, 91/2 inches; length, 13 inches

A vikw of a wide valley, with a large elm in the middle distance, and mountains beyond. 'The effect is in early autumn while the grass is still green and the foliage is beginning to color.

Signed at the lower left, and dated '83.

William T. Evans Collection, New York, 1900, Catalogue No. 133. 
No. 91

\section{J. FRANCIS MURPHY, N.A.}

American: 1853-

\section{THE RIVER}

Height, 9 inches; length, 11 inches

A complete little landscape with various elements combined in a pleasing ensemble. On the left is a placid river; in the foreground green meadows with a group of trees in the right center; overhead a grạ sky.

Signed at the lower right, and dated '90.

T. Kirkpatrick Collection, New York, 1900. 


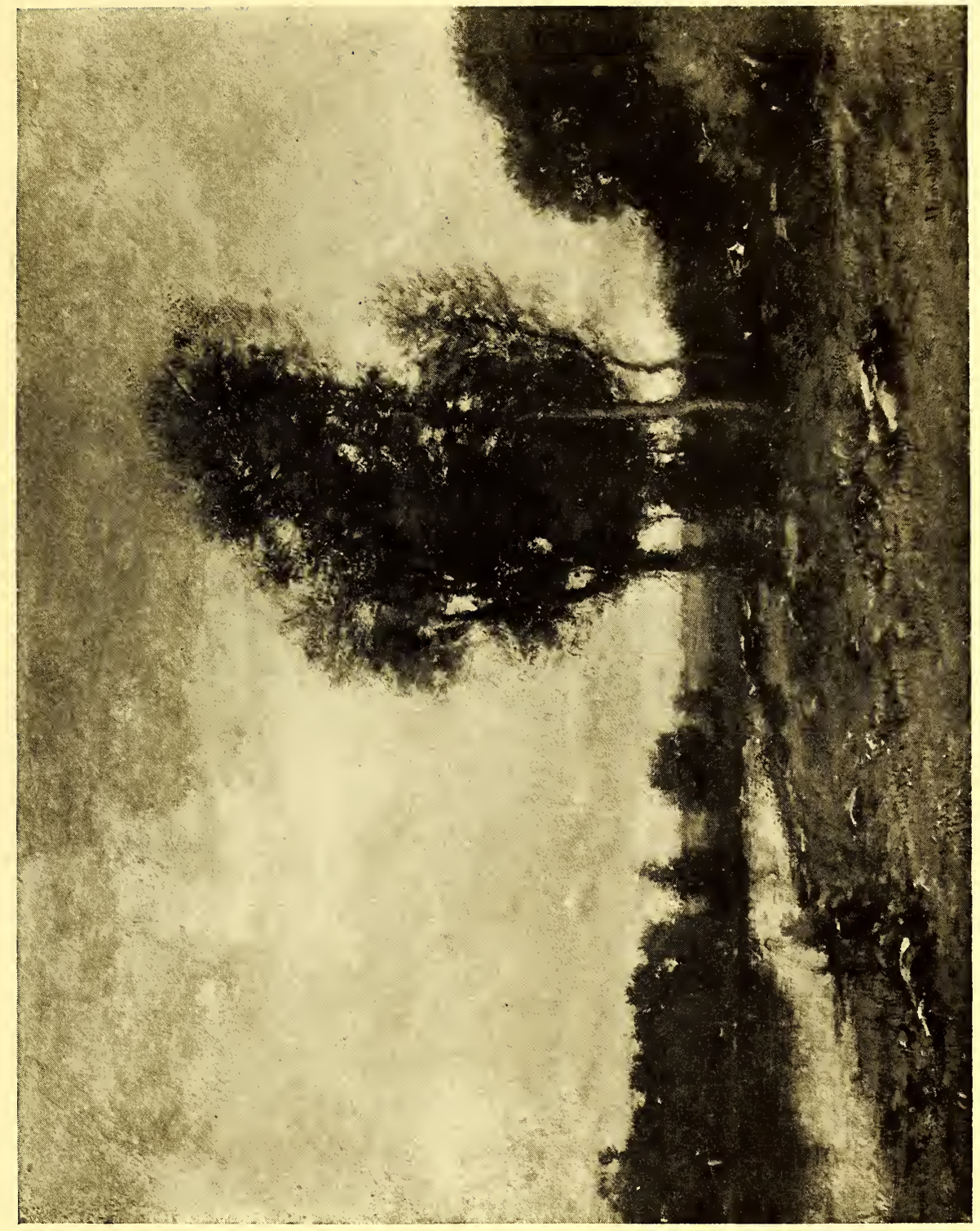




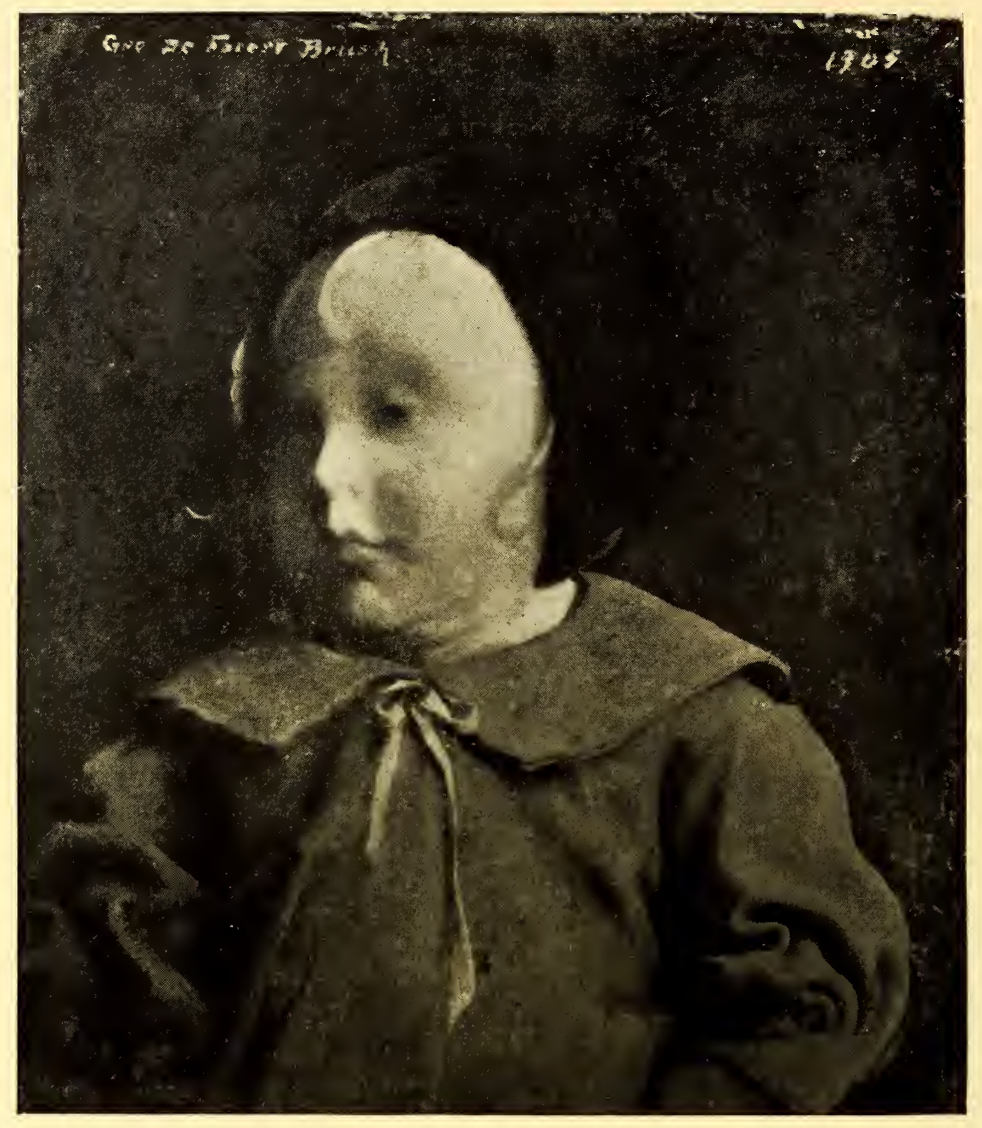

No. 92

\section{GEORGE DE FORES'T BRUSH, N.A.}

American : 1855-

\section{BOY WITH A GREEN CAP}

Millboard: Height, 7 inches; width, $61 / 4$ inches

A half-Length picture of a chubby child with rosy cheeks, the face in three-quarter view to the left. On his head is a close-fitting cap of dark green and he wears a jacket of brown with wide collar, fastened at the neck with a narrow pink ribbon. The work shows the characteristic technical methods of a celebrated American artist and is a typical example.

Signed at the upper left, and dated at the upper right, 1905. 


\section{GEORGE FULLER, A.N.A.}

American : $1822-1884$

\section{SHEARING THE DONKEY}

\section{Height, 13 inches; length, 18 inches}

A Brown donkey is standing in side view in the middle of the picture, while a man with a shirt of dull red bends over his hindquarters, clippers in hand. On the right a woman is seen passing, and some chickens are pecking about the yard. In the distance are trees and a glimpse of sky.

Signed G. F. at the lower left.

Purchased from William Macbeth, New York, 1905.

No. 94

\section{DWIGH'T WILLIAM TRYON, N.A.}

American : 1849-

\section{MOONRISE-OCTOBER}

Panel: Height, 11 inches; length, 16 inches

A poETIC rendering of an early evening effect, painted in quiet tints. Stony pastures occupy the foreground and in the middle distance is a belt of trees; beyond, the moon is just rising. lighting up the sky. The general effect is one of restraint and sobriety.

Signed at the lower left.

Purchased from N. E. Montross, New York, 1902. 
No. 95

\section{HOMER D. MAR'TIN}

Americax : $1836-189 \%$

\section{RUBY STRONG-NORMANDY}

\section{Height, 14 inches; width, 11 inches}

A figure picture by Homer Martin, portraying a little girl, bare headed and bare legged, with heavy dark hair and wearing a striped jacket of green and red and a skirt of black. She is depicted standing on a Normandy beach, her hands behind her back and the head in profile view as she gazes out to sea. The horizon is placed low on the canvas and a sky of bluegray forms the background for the little figure.

Purchased from William Macbeth, March 8, 1904; purchased by Mr. Macbeth from Mrs. Martin. There was a painting of Martin's studio showing "Ruby Strong" tacked up on the wall. This painting was photographed and the negative is in the possession of Mr. Macbeth, who had seen the original painting when in possession of Mr. Martin-that is, the painting on the studio wall. 


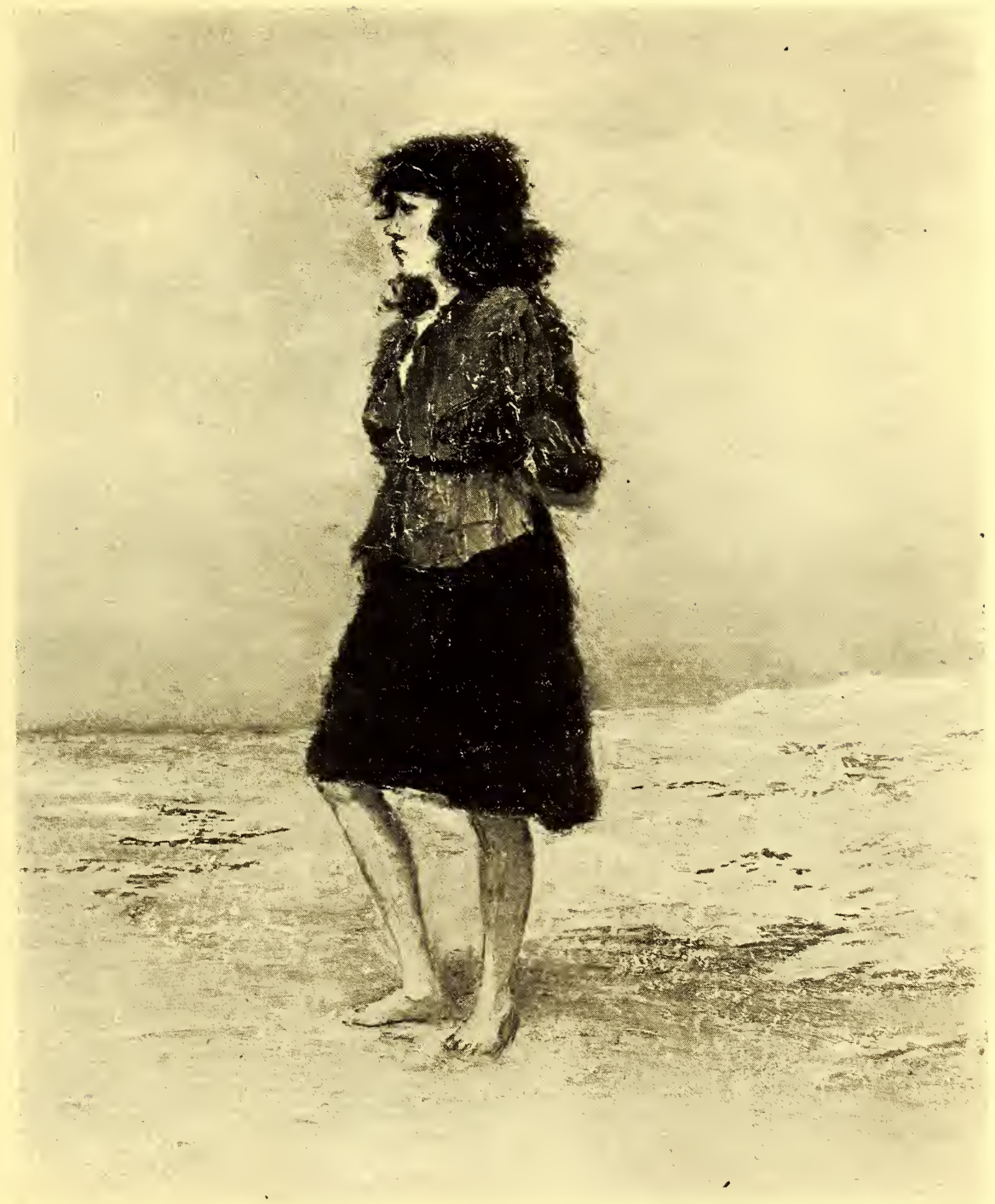


No. 96

\section{HOMER D. MAR'TIN, N.A.}

American: $1836-1897$

\section{MOONLIT POND-HONFLEUR}

\section{Height, 10 inches; length, 14 inches}

A pastoral in Normandy showing a pond in the foreground, some trees on the farther bank and the crescent moon, in the twilight, near the horizon. The effect is depicted in harmonious grays.

Signed at the lower right.

Purchased from William Macbeth, New York, February, 190\%. Purchased by Mr. Macbeth from Mr. Frank Lethbridge, British ViceConsul at Ghent, Belgium, who had obtained the picture direct from the artist. 


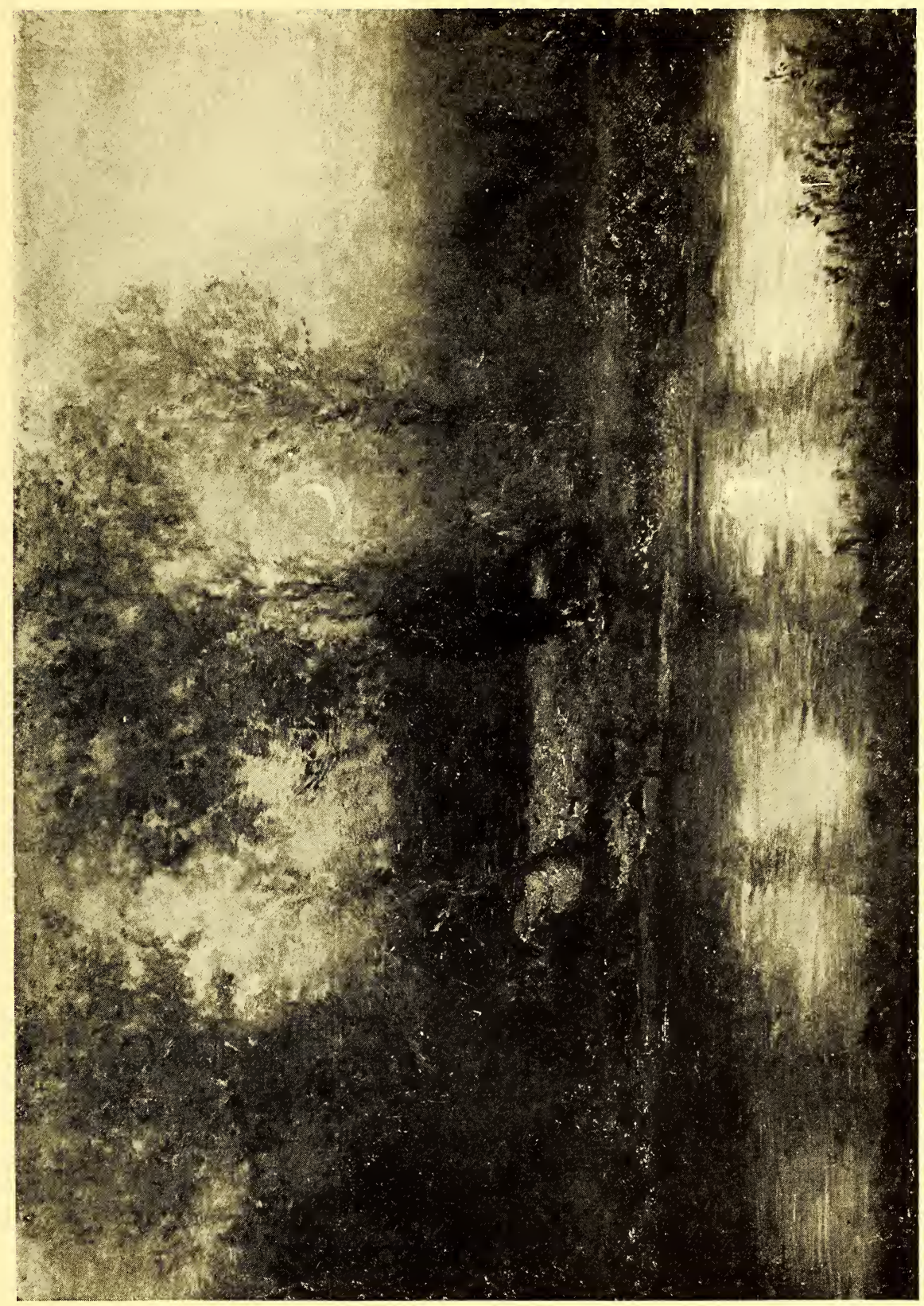


No. 97

ALEXANDER H. W Y AN'T, N.A.

American : $1836-1892$

\section{EVENING-EARLY AUTUMN}

\section{Height, 12 inches; length, 16 inches}

A LANDSCape in quiet tints of gray and subdued greens and browns. In the middle portion of the picture, on the left, is a group of trees, and there are glimpses of a little stream, here and there in the foreground and in the middle distance, reflecting the gray of a sky filled with clouds.

Signed at the lower right.

From William Macbeth, New York, 1902. 


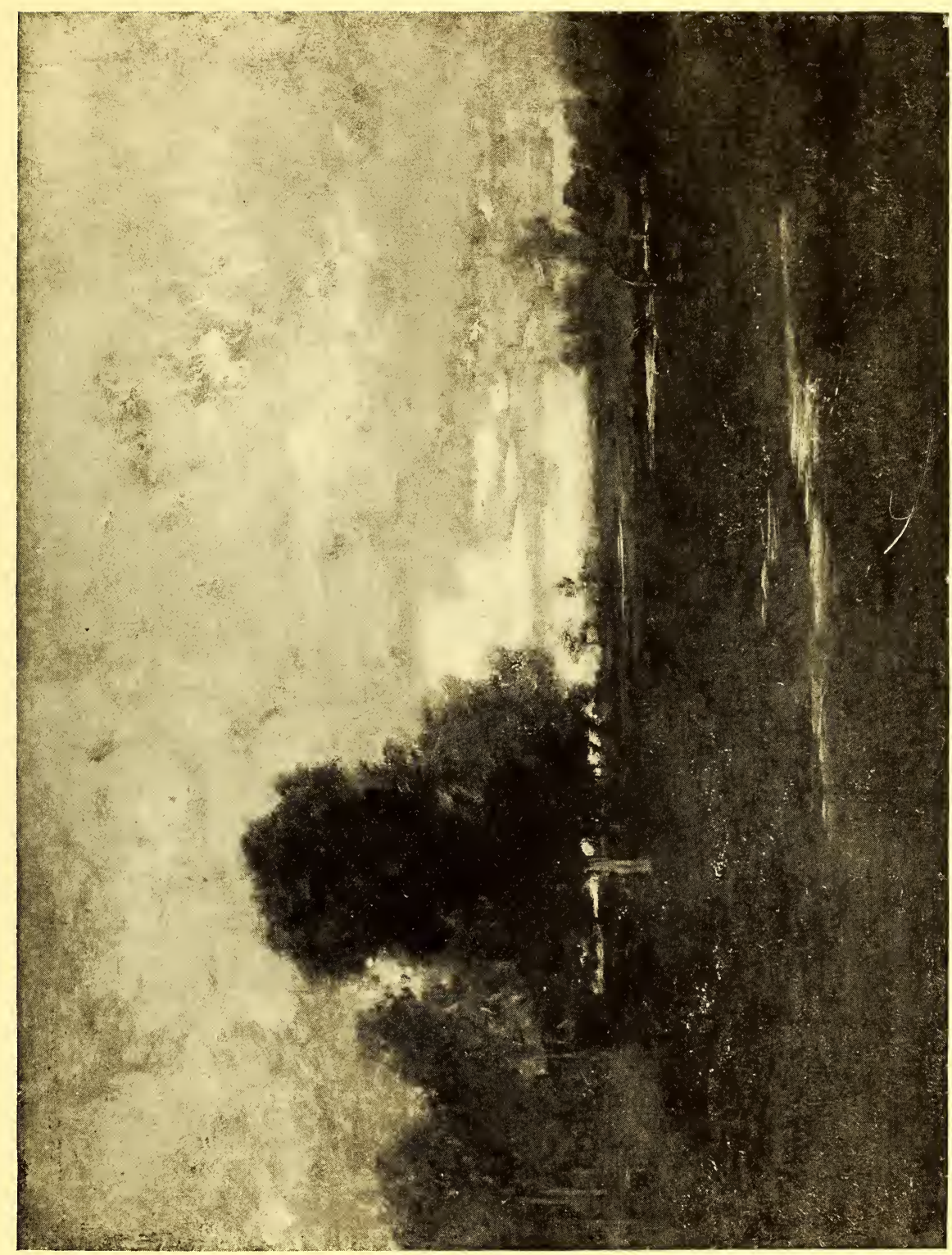


No. 98

\section{J. FRANCIS MURPHY, N.A.}

American: 1853-

\section{OCTOBER AFTERNOON}

Height, 11 inches; length, 19 inches

As autumn pastoral, with a qualified color scheme of tawny yellows, greens and grays; a gray sky mingled with blue, a grove of trees and a pool in the foreground. Haystacks and a barn are seen in the middle distance.

Signed at the lower left, and dated 1902.

Purchased from George H. Tappen, New York, 1902. 


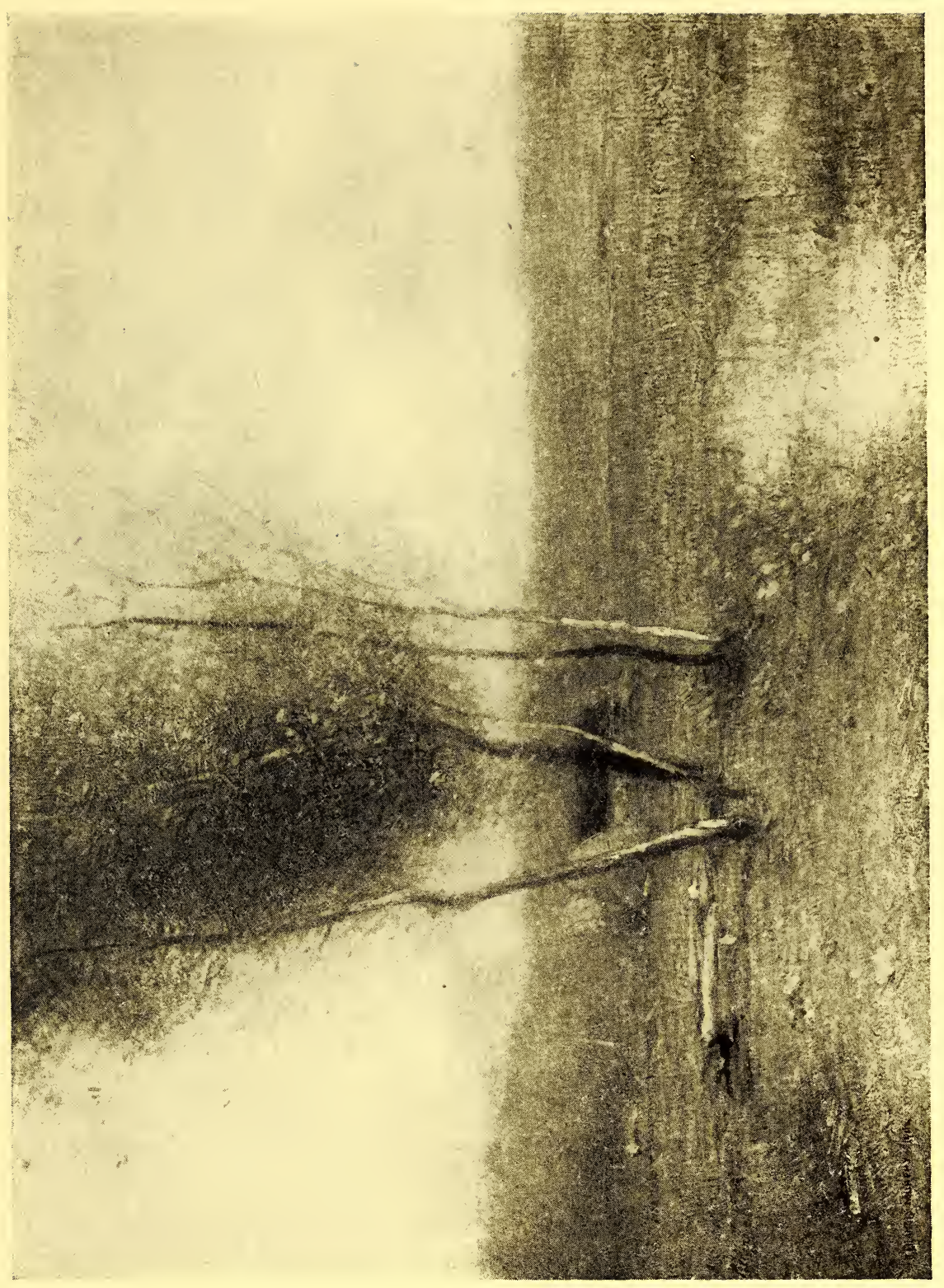




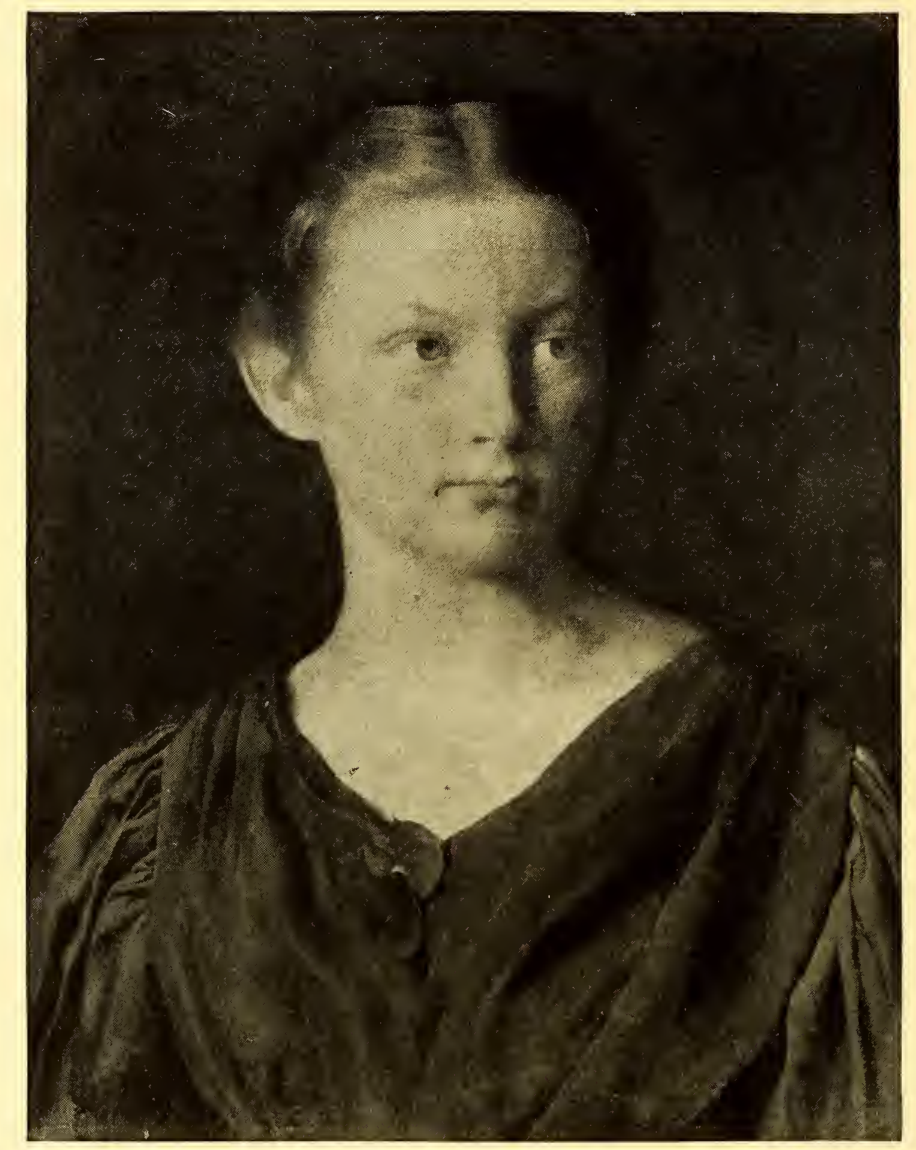

No. 99

\section{GEORGE DE FOREST BRUSH, N.A.}

Anerican: $1855-$

\section{GIRL'S HEAD}

Height, 14 inches; width, 101/2 inches

A HEAD and bust picture of a trim and wholesome-looking girl, with fair hair and blue eyes, the head turned slightly to the right, and wearing a brown frock. The head is precisely drawn and modeled with simplicity.

Signed at the left (above the shoulder), and dated 1904. 


\title{
HOMER D. MARTIN, N.A.
}

Americhin : $1836-1897$

\section{THE DUNES}

Water Color: Height, 10 inches; length, 14 inches

From a level space in the foreground, partly covered with grass and herbage, rises a steep hillside, rock crowned, and a road, on the left, leading up to its top. A springtime sky of whitish gray with a touch of blue is in agreeable contrast to the colorful notes of the dunes.

Signed at the lower left, and dated 1883.

Purchased from William Macbeth, New York, December, 1904. Purchased by Mr. Macbeth from Obach \&. Co., 168 New Bond St., London, this firm acting as agents for Mr. John Hebb, an architect of London. Mrs. Martin had informed Mr. Macbeth that Mr. Hebb had purchased paintings from her husband. This painting is reproduced in Mrs. Martin's book on her husband's work.

No. 101

\section{HENRY GOLDEN DEARTH, N.A.}

\author{
Americhin: 1864-
}

\section{THE EMERALD POOL}

\section{Panel: Height, 13 inches; length, 161/4 inches}

A color symphony in which the principal notes are qualified greens and blues, with accents of orange and red. A figure of a young woman, in a frock of warm-tinted white, is seen seated on the bank of the pool, the water of which reflects foliage and a brilliant sky.

Signed at the lower right.

Purchased direct from the artist, 1912. 


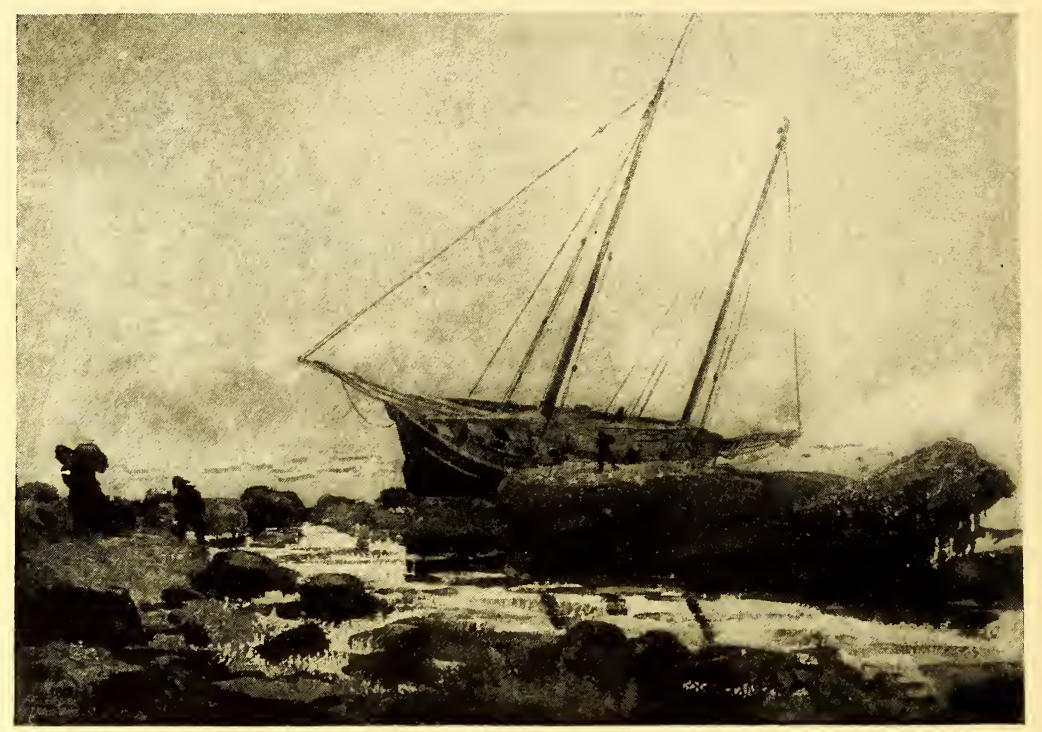

No. 102

\section{WINSLOW HOMER, NA.}

Anerican : $1836-1910$

\section{A WRECK NEAR GLOUCESTER}

Water Color: Height, 1t inches; length, 20 inches

A Two-MAasted sailing ressel is here seen cast. by a storm upon the rocky shore. Some figures of men are indicated on the sloping deck of the ship and on shore, carrying away burdens on their shoulders, showing that salvage is in progress. The rocks of brown and the sky of gray are contrasted with the dark blue tint of the hull of the vessel.

Signed at the lower left, and dated 1880.

Purchased from Edward C. Stedman, New York, 1905. 
No. 103

\title{
THEODORE ROBINSON
}

\author{
American: $1854-1896$
}

\section{THE THATCHED COT'TAGE}

\author{
Height, 16 inches; width, 14 inches
}

\begin{abstract}
A harmony of grays and greens, with a sky of blue in color unison. On the right is a cottage with high, sloping, thatched roof; on the left, a group of trees. The effect is in sunlight.

Purchased from William Macbeth, New York, March, 1908; purchased by Mr. Macbeth from Mrs. McCahill, a pupil of Theodore Robinson.
\end{abstract}

No. 104

\section{J. FRANCIS MURPHY, N.A.}

Anerican: 1853 -

\section{CHANGING MAPLES}

\section{Height, 16 inches; length, 22 inches}

A Landscape with very strong contrasts of dark and light presented by its sky, white with black stormy clouds, and the country in foreground and the distance low-toned under the shadows. In the left center of the picture a group of maples with foliage of tawny yellows and red gives a lighter note, and on the right a break in the sky, with a gleam of light in the clouds, gives another to balance it.

Signed at the lower right, and dated '88.

Purchased from William Macbeth, New York, 1905. 
No. 105

\section{WILLIAM MERRITT CHASE, N.A. \\ Anerican : $1849-1916$}

\section{NEAR BAY RIDGE}

Height, 10 inches; length, 15 inches

A Harbor scene with the water occupying the foreground and vessels, buildings, piers and other landing places crossing the picture in the middle distance. The sky of gray, mingled with blue, is reflected in the water, and a few notes of white, red and black, accenting the shipping, diversify the general effect.

Signed at the lower right.

William T. Eżans Collection, New York, 1913. 


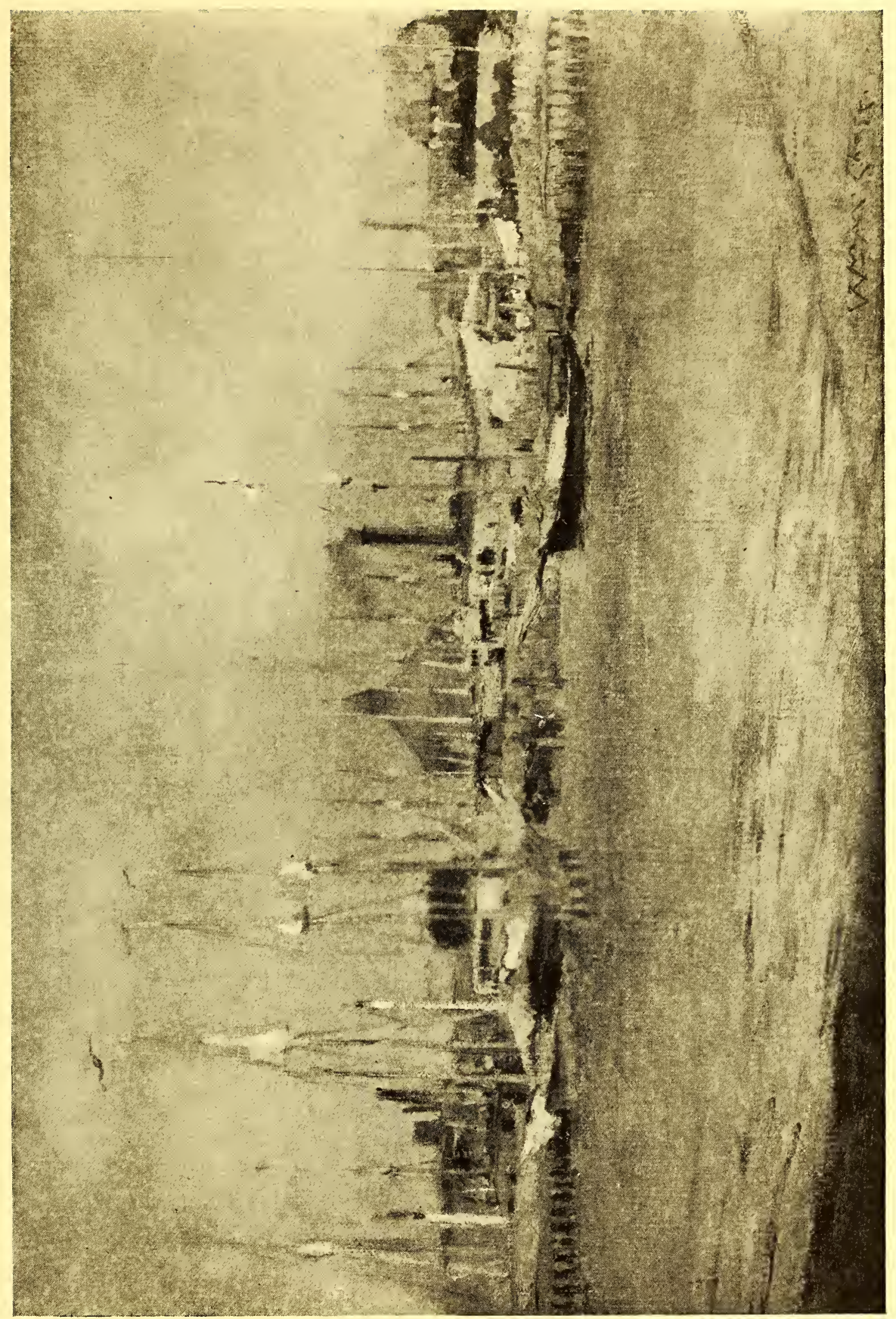


No. 106

\section{ALEXANDER H. WYANT, N.A.}

Americhin : $1836-1892$

\section{THE OLD SAND ROAD}

Height, 12 inches; length, 16 inches

A LANDSCAPE composed of a plain, stretching far away to a low horizon, and an autumn sky of gray. Through the middle of the picture, over the flat lands, runs a sandy road. The immediate foreground is in shadow and this portion of the picture is balanced by clouds in the upper part of the sky which are darker than the space below them. Thus, with the light concentrated in the central portion of the picture, the effect is made striking, although the landscape, in its general effect, is rendered in the quietest of tints.

Signed at the lower right center.

Purchased from Mrs. A. H. Wyant, New York, 1902. 


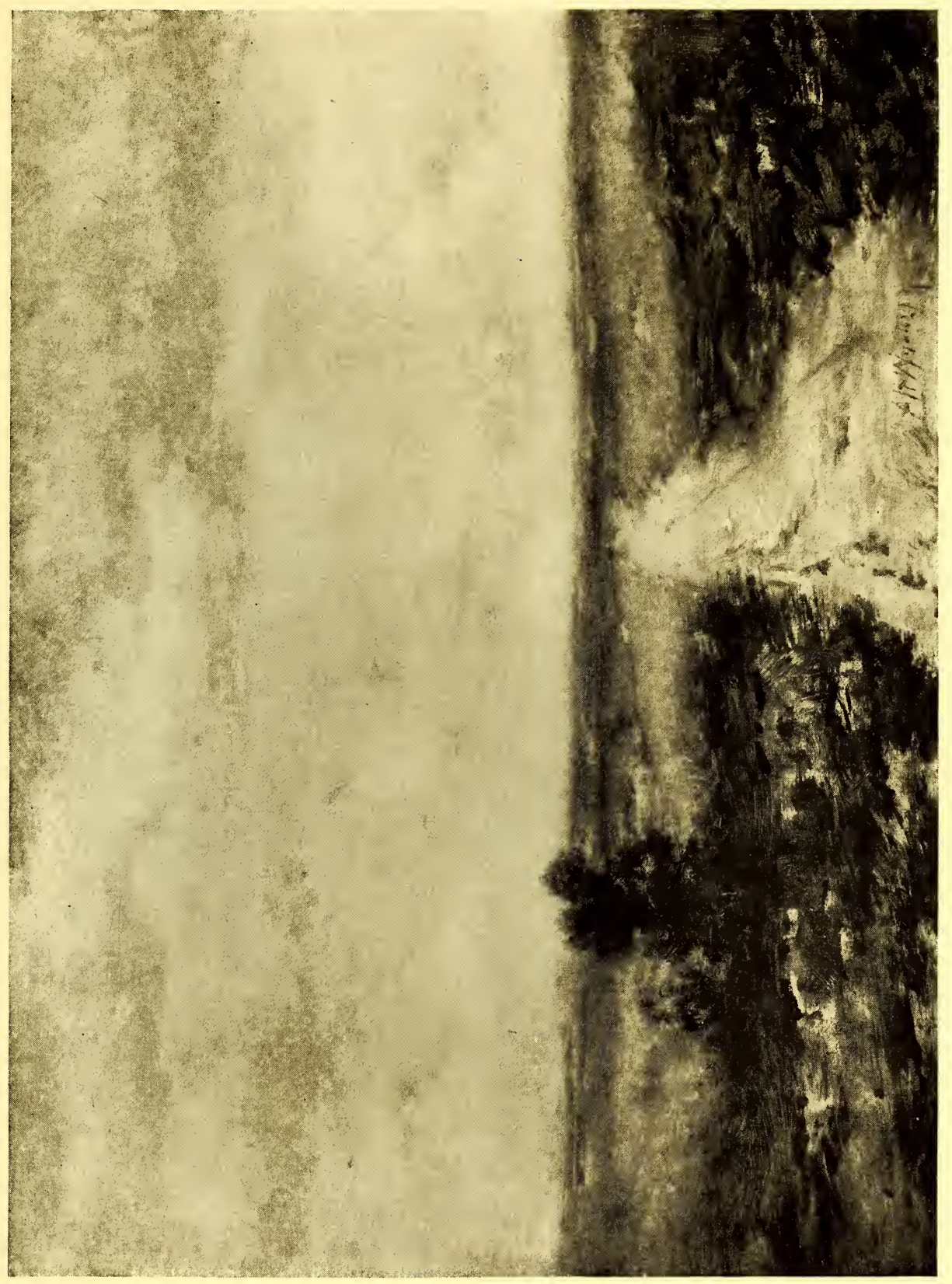


No. 107

\section{HOMER D. MARTIN, N.A.}

American : 1836-1897

\section{INDIAN SUMMER}

\section{Height, 163/4 inches; width, 12 inches}

A picture of the American autumn which bears on its face convincing evidence of truth to nature. The entire foreground is occupied by a shallow stream and a piece of its gravelly bank. In the middle distance the stream is bordered by trees and through the foliage appears a sky of pale blue. The water reflects the foliage and the sky while, at the same time, its transparency discloses portions of the stream's sandy bed.

Thomas B. Clarke Sale, New York, 1899, Catalogue No. 345. 


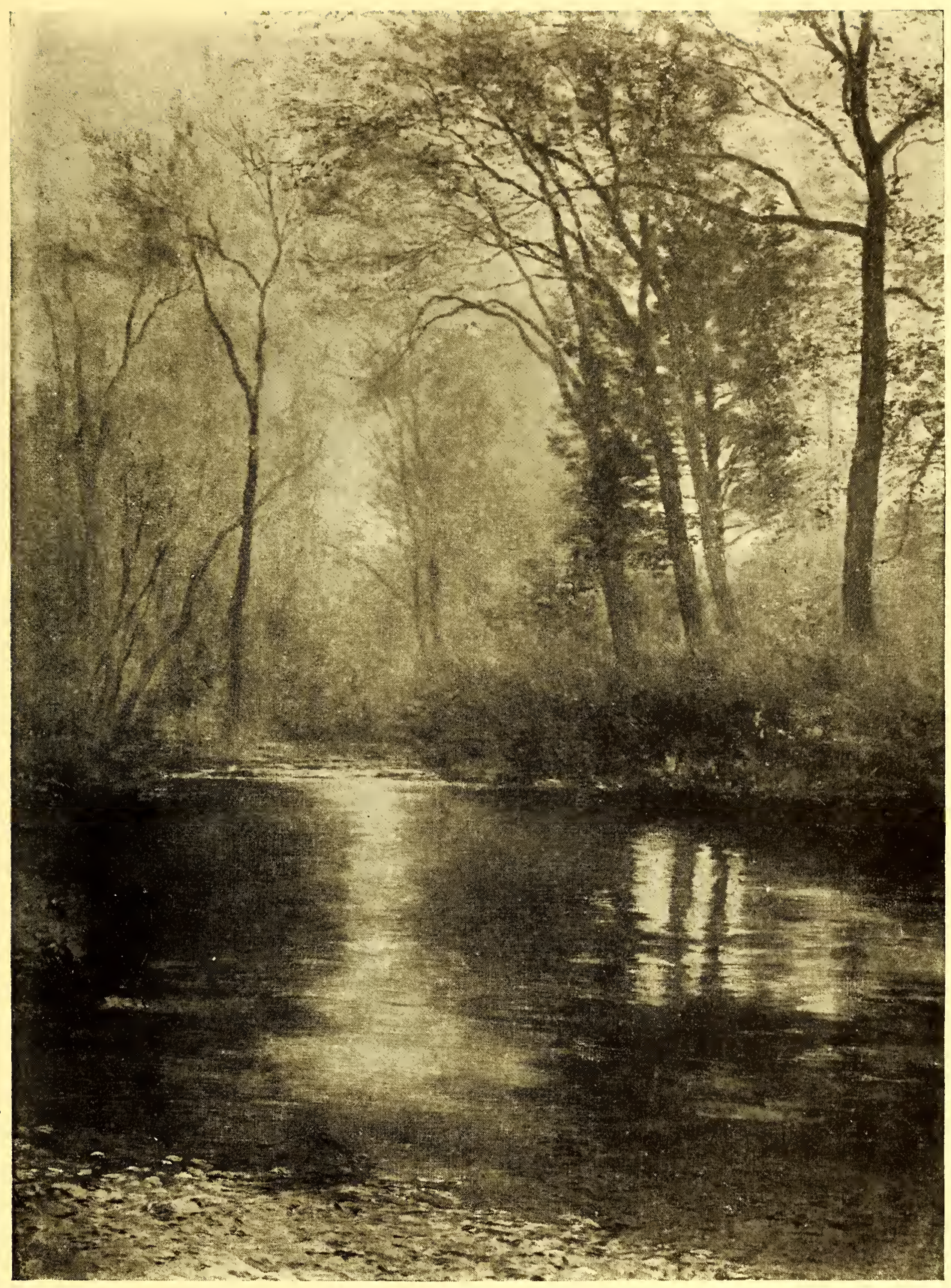


No. 108

\section{ROBERT C. MINOR, N.A.}

Americhis: $1840-1904$

\section{EARLY AUTUMN}

Height, 16 inches; length, 21 inches

Av excellent example of the landscape art of Robert C. Minor, in a well-balanced composition presenting a foreground of grass and herbage, while on the left are several trees whose branches and foliage reach to the top of the picture. On the right, beyond a road which winds through the fields, is another group of trees, the foliage gently illumined by afternoon sun; in the distance a line of blue hills. The sky of broken white and gray clouds, with some spaces of blue, is luminous and effective. 


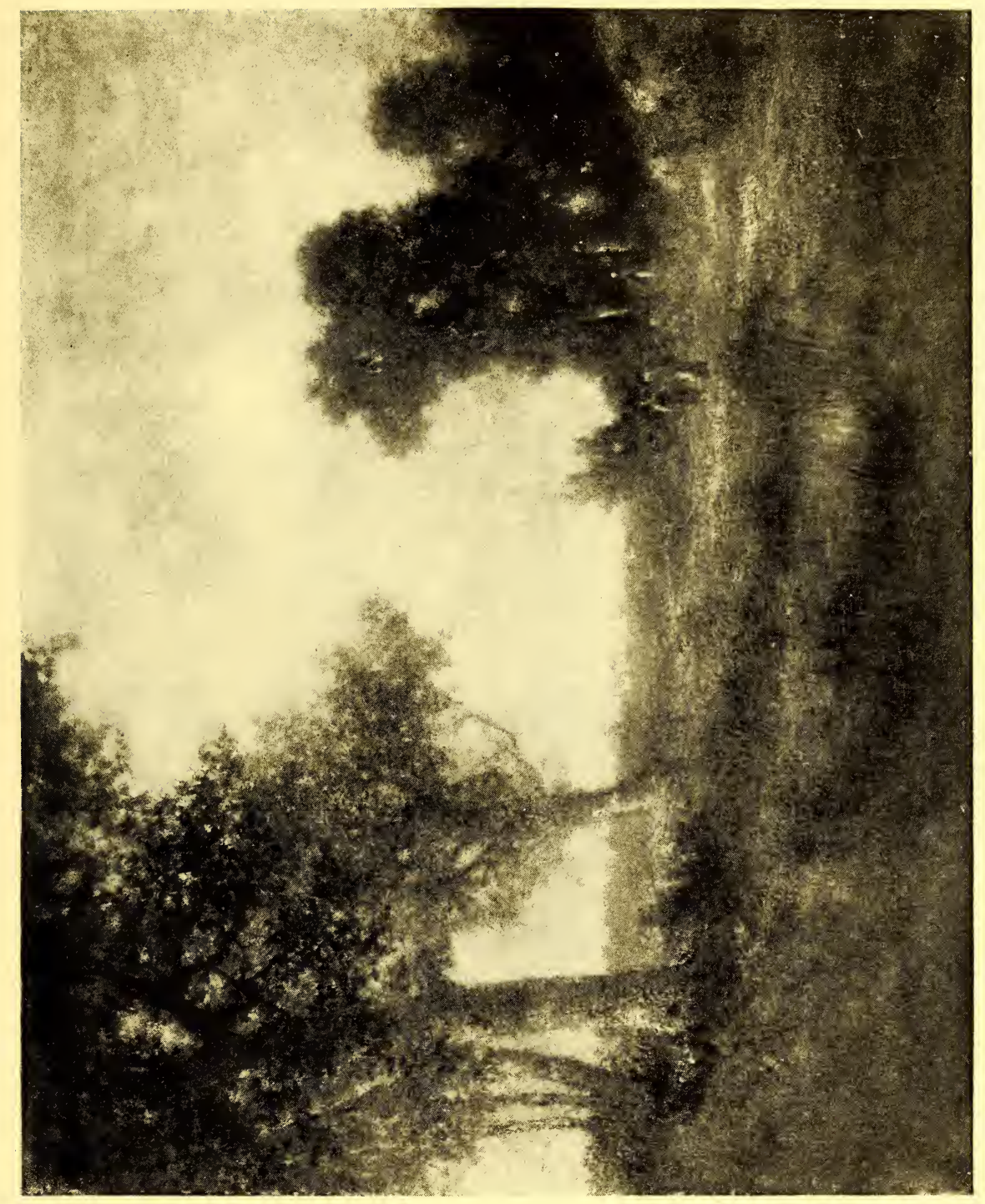


No. 109

\section{ALEXANDER II. W'YAN'T, N.A.}

American: $1856-1892$

\section{A BROOK IN THE CATSKILLS}

Height, 14 inches; length, 20 inches

A Wyant with a picturesque subject, including a placid stream in the middle foreground, meadows on either side, and a group of trees in the left center of the composition. Over all is a sky of delicate gray clouds with some blue intervening in the upper portion.

Signed at the lower right. 


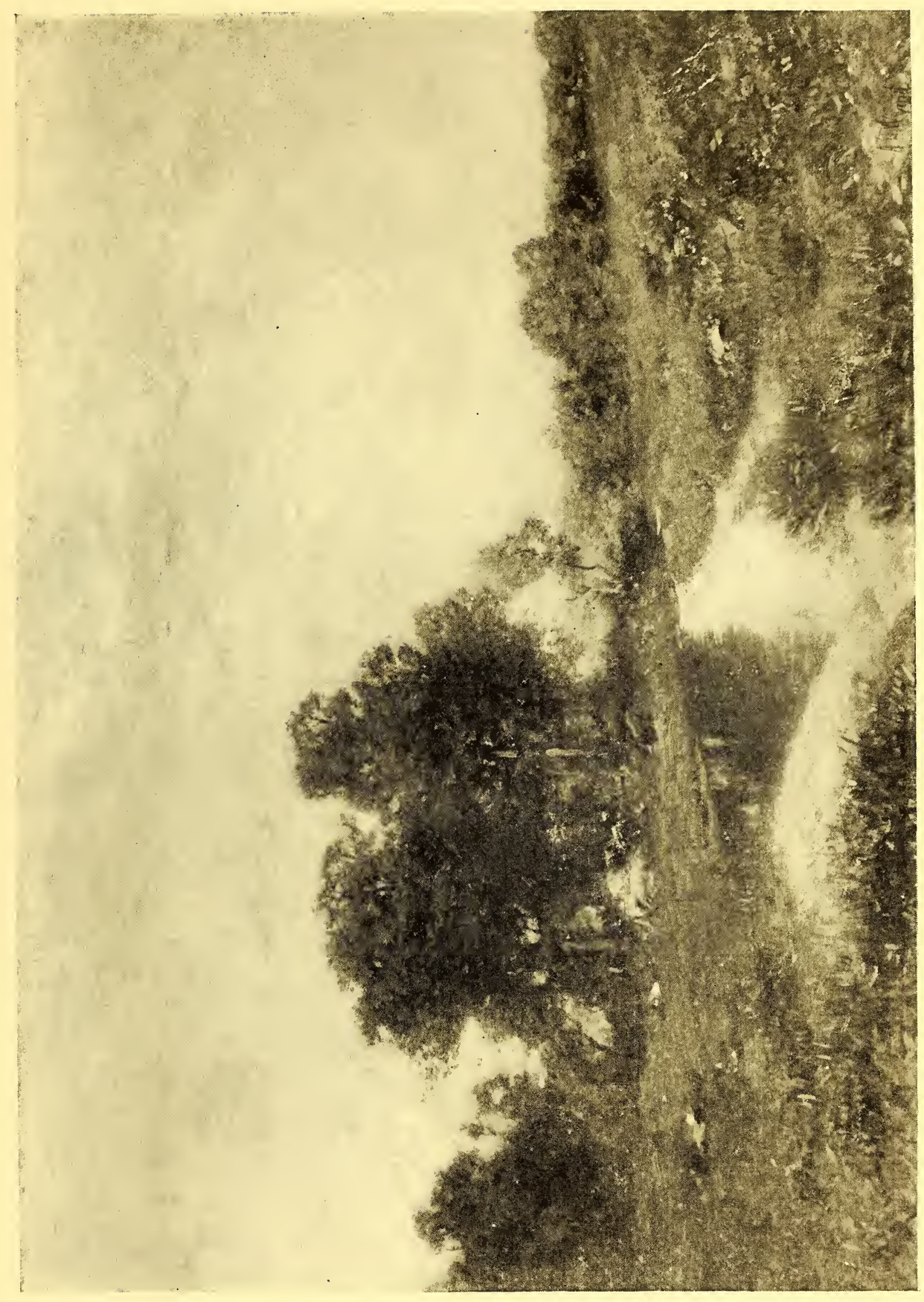


No. 110

\title{
FREDERICK BALLARD WILLIAMS, N.A.
}

\author{
Americhin: 18\%1-
}

\section{HALCYON DAYS}

Height, 16 inches; length, 24 inches

A Group of four female figures in a setting of landscape, with a view of the sea and sky beyond. Three of the figures are grouped together in the middle left portion of the picture; two being seated and one standing, the last holding up a baby in her arms. The fourth figure, in the right center, is advancing towards the spectator and holds a rose in her outstretched right hand. The costumes show tints of yellow, blue, pink and white.

Signed at the lower left.

Purchased from William Macbeth, New York, $190 \%$. 


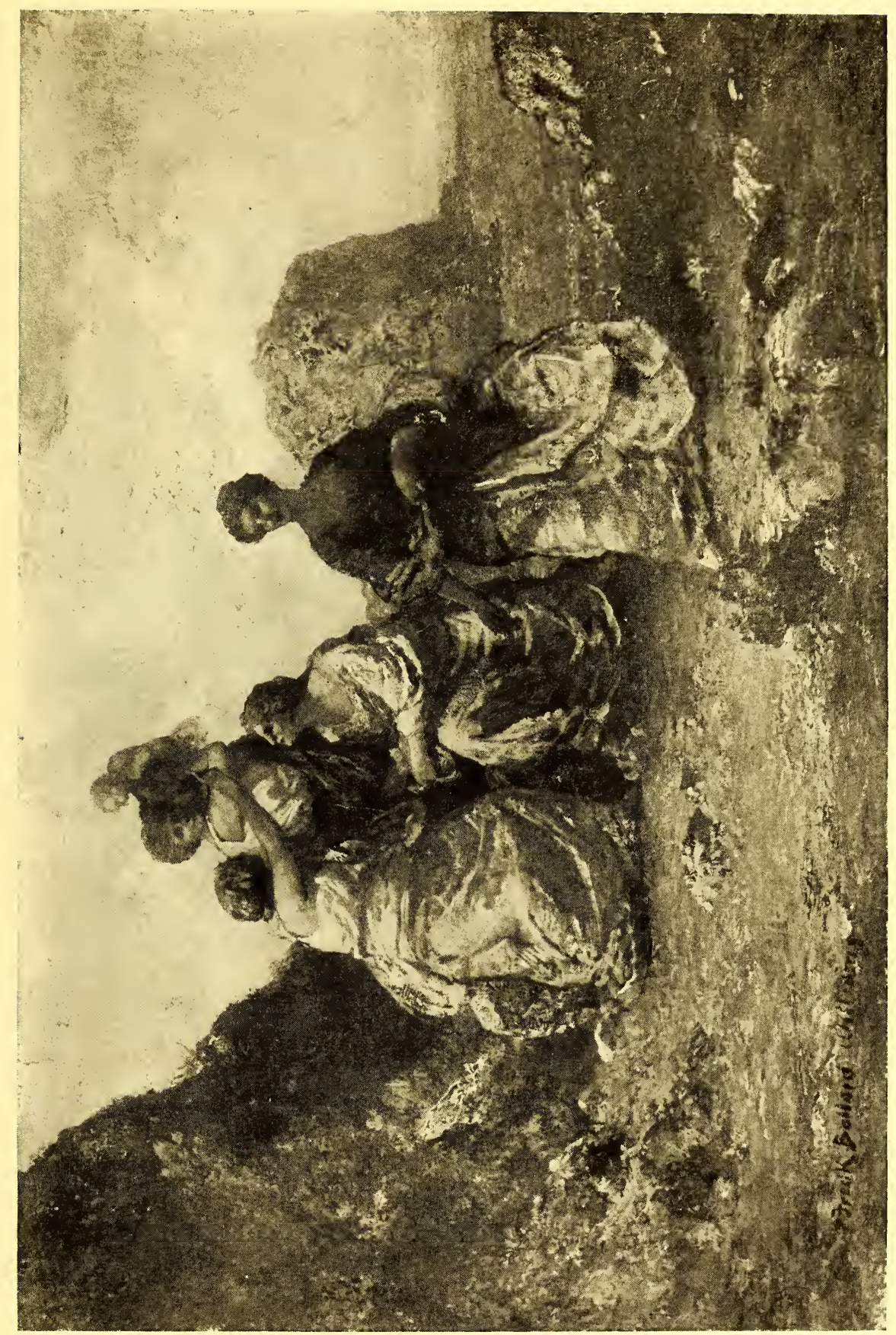


No. 111

\title{
HENRY GOLDEN DEARTH, N.A.
}

\author{
American : 1864-
}

\section{THE THREE-MASTER}

Panel: Height, 18 inches; length, 213/4 inches

A HARMony of sober tints-grays, blacks, yellows, browns, dull pinks and reds-showing a sailing vessel, in side view, moored in the bassin of a French seaport. The masts and rigging stretch upward before a background of gray sky and the houses lining the harbor quays.

Signed at the lower right

Purchased direct from the artist, New York, 1912. 


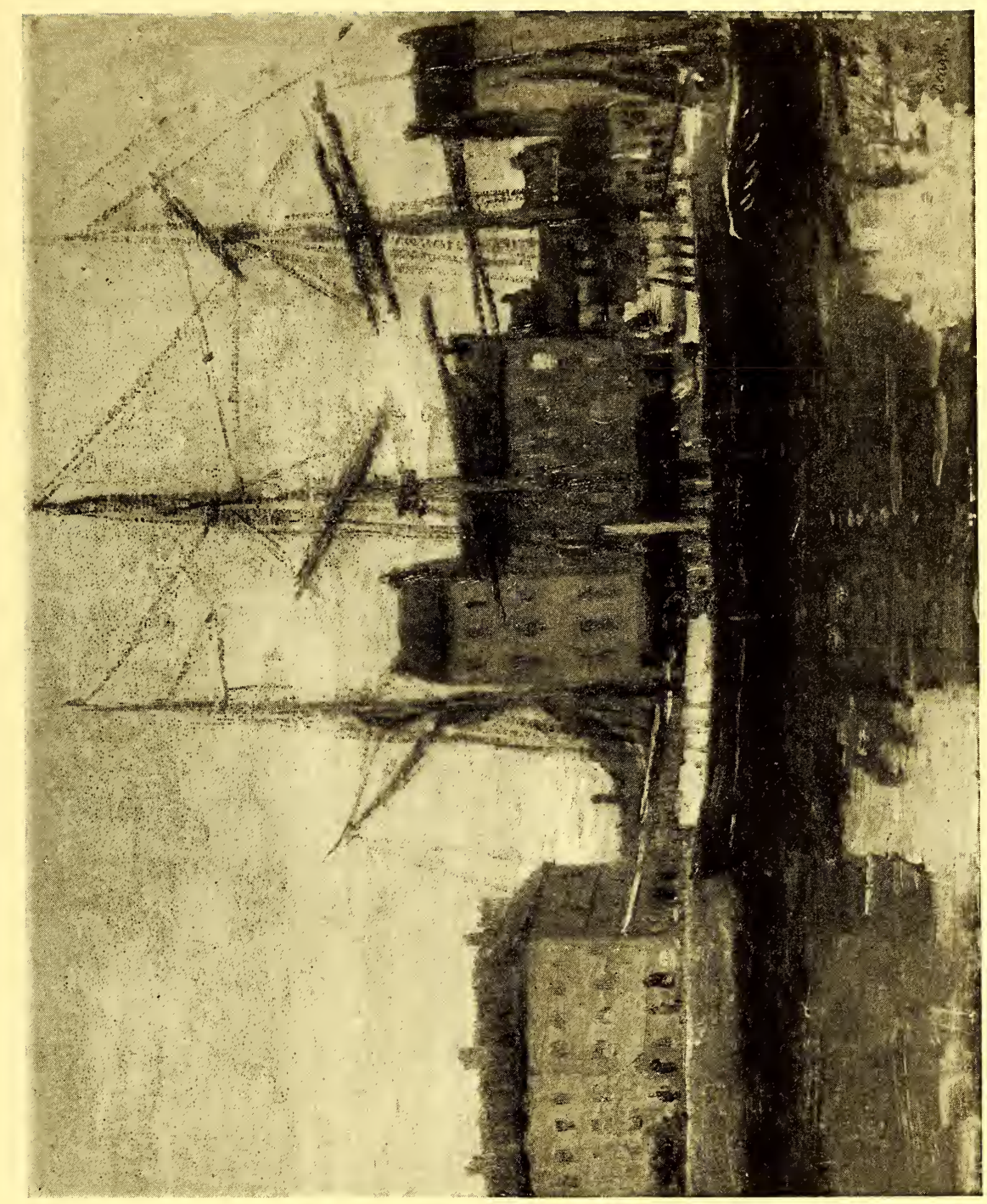


No. 112

\section{J. FRANCIS MURPIIY, N.A.}

Anerican : 1853

\section{SPRINGTIME IN THE CATSKILLS}

Height, 16 inches; length, 22 inches

A Landscape of subtle general effect, in which the elements of the composition are level fields, with a brook in the right foreground; some trees in spring foliage on the extreme right, and others in the distance, with a line of hills at the horizon. Over all is a sky of tender gray. The picture is painted in tints that are qualified by the atmospheric effect of a somewhat misty day in springtime.

Signed at the lower right, and dated 1902. 


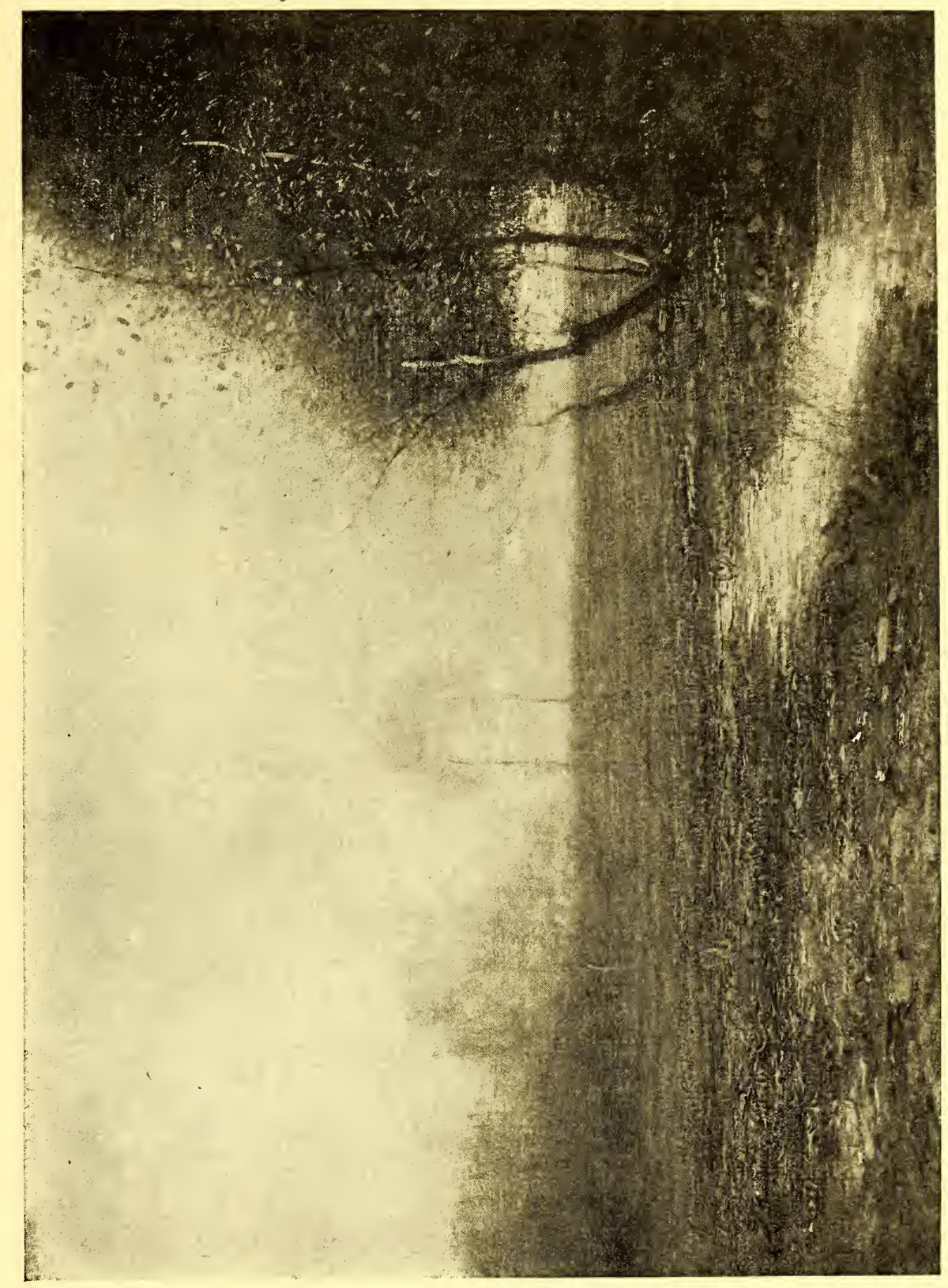


No. 113

\section{RALPH ALBERT BLAKELOCK, N.A.}

American : 184\%-

\section{EARLY EVENING}

\section{Height, 16 inches; length, 24 inches}

In the foreground is a sheet of water which reflects the light of the full moon, seen in the middle of a sky mostly filled with clouds. Some trees and bushes diversify the forward planes of the picture, and in the distance is a range of blue hills.

Signed at the lower right.

William T. Evans Collection, New York, 1900, Catalogue No. 10. 


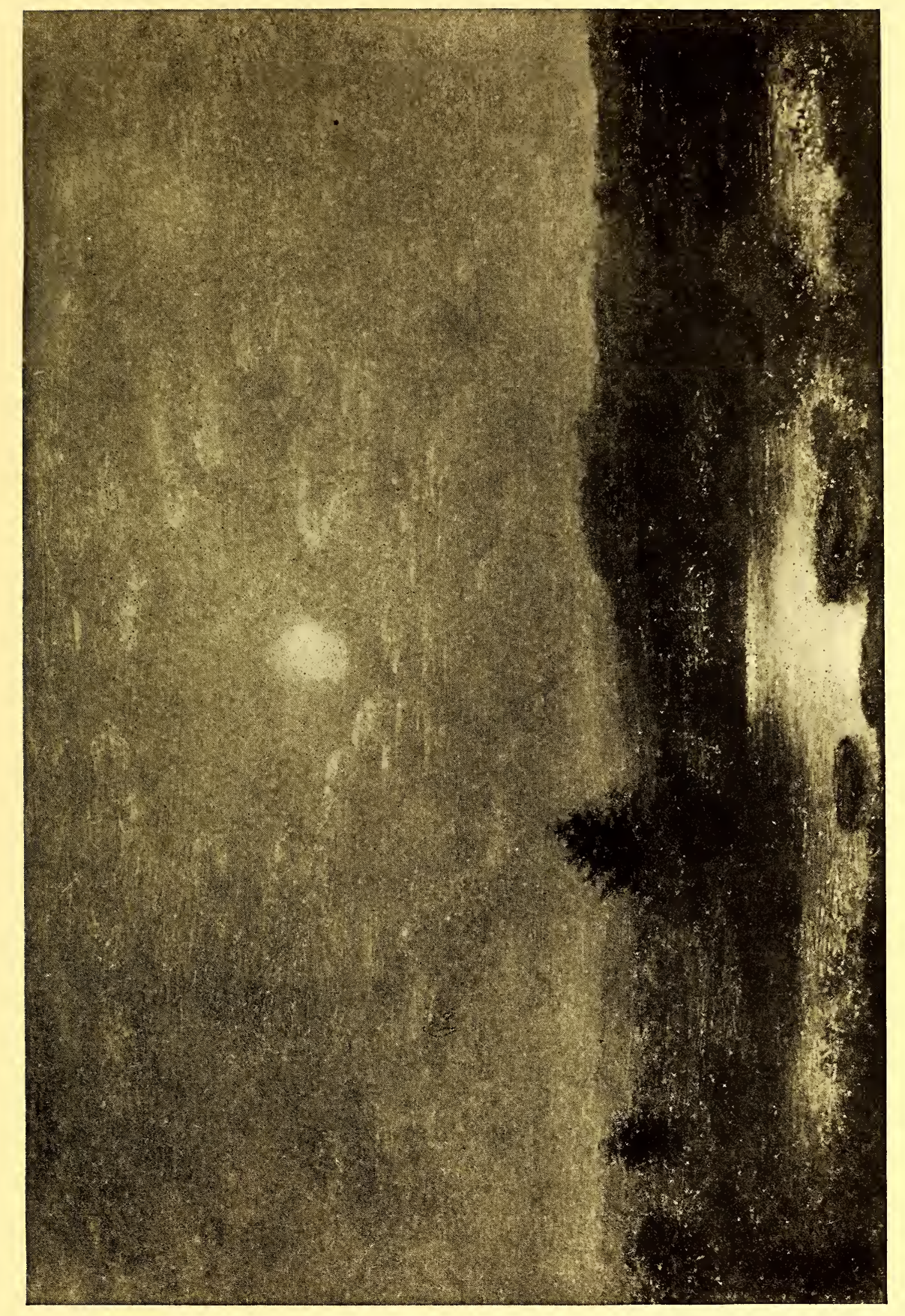


No. 114

\title{
THEODORE ROBINSON
}

\author{
American : $1854-1896$
}

\section{TWACHTMAN'S HOUSE}

Height, 18 inches; length, 22 inches

A winter landscape showing the roofs of a country house and its walls and garden in a mantle of snow. The whole is in shadow except for a part of the picture on the left where the sun gleams on the snow-covered ground. This excellent example of the art of Theodore Robinson shows his characteristic feeling for color and his well-known quality of truthful observation.

Signed at the lower left, and dated 17 JAN. 1892.

William T. Evans Collection, New York, 1900, Catalogue No. 146. 


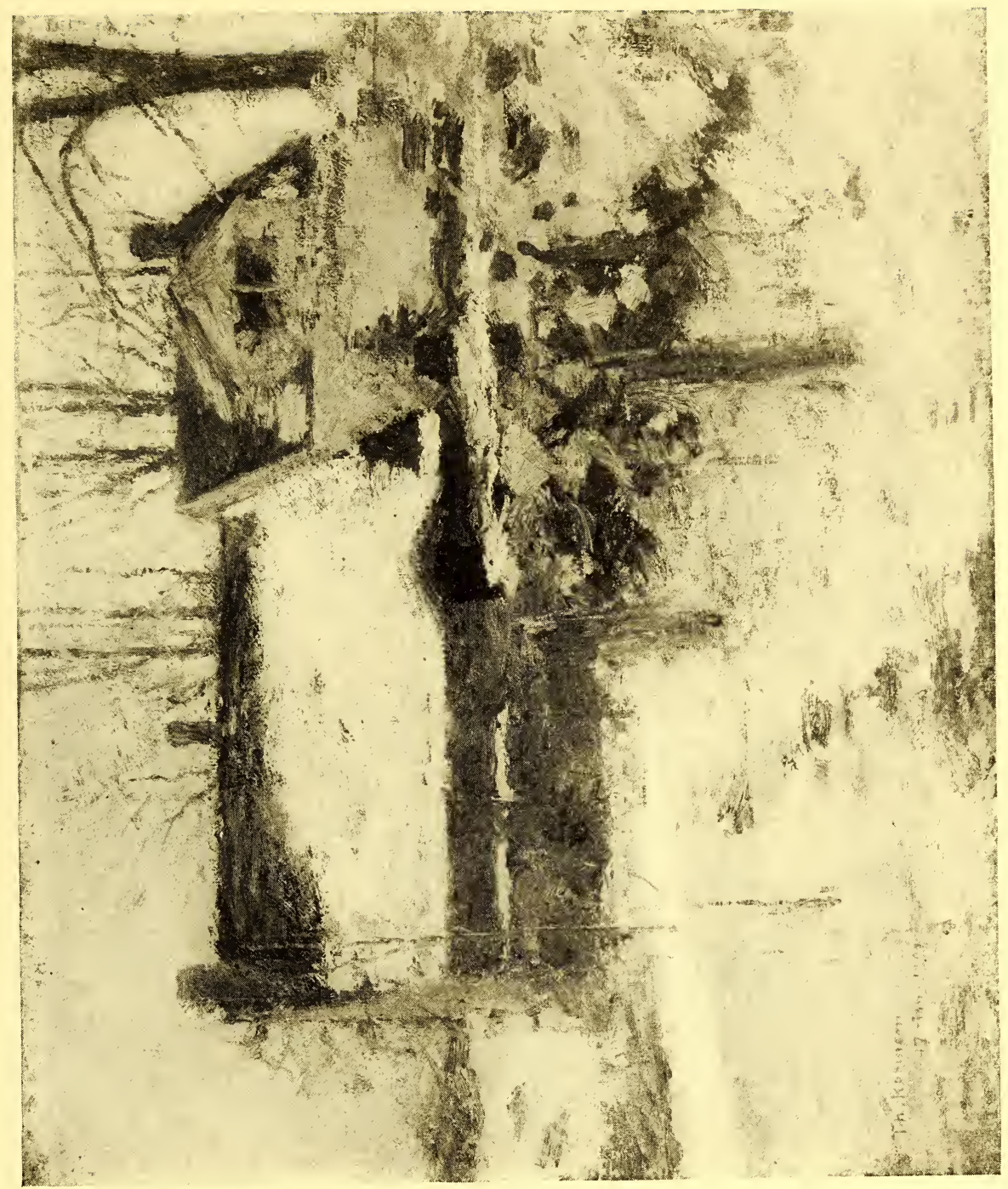


No. 115

\section{WINSLOW HOMER, N.A.}

American : $1836-1910$

\section{PERILS OF THE SEA}

Water Color: Height, 14 inches; length, 20 inches

Two fisher maidens are seen standing on a dock in the foreground and below is a group of sailor men, one, with arm extended, pointing out to sea. The middle portion of the picture shows the ocean, and above is a dark, stormy sky. A stirring depiction of an incident in the seafarer's life in which tragedies are so numerous, painted in a color scheme of subdued general tone.

Signed at the lower right, and dated 1881.

Thomas B. Clarke Collection, New York, 1899, Catalogue No, 269. 


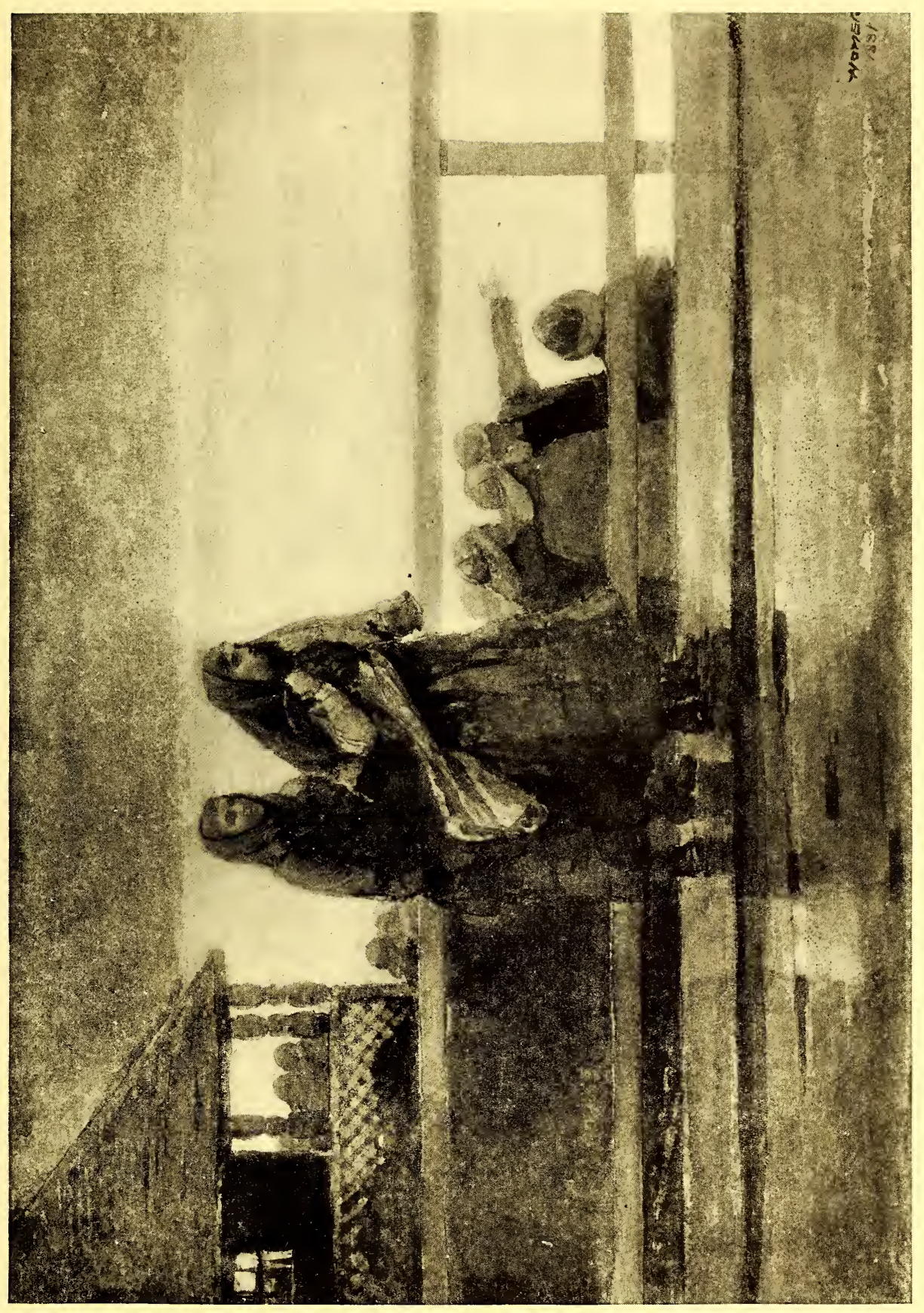




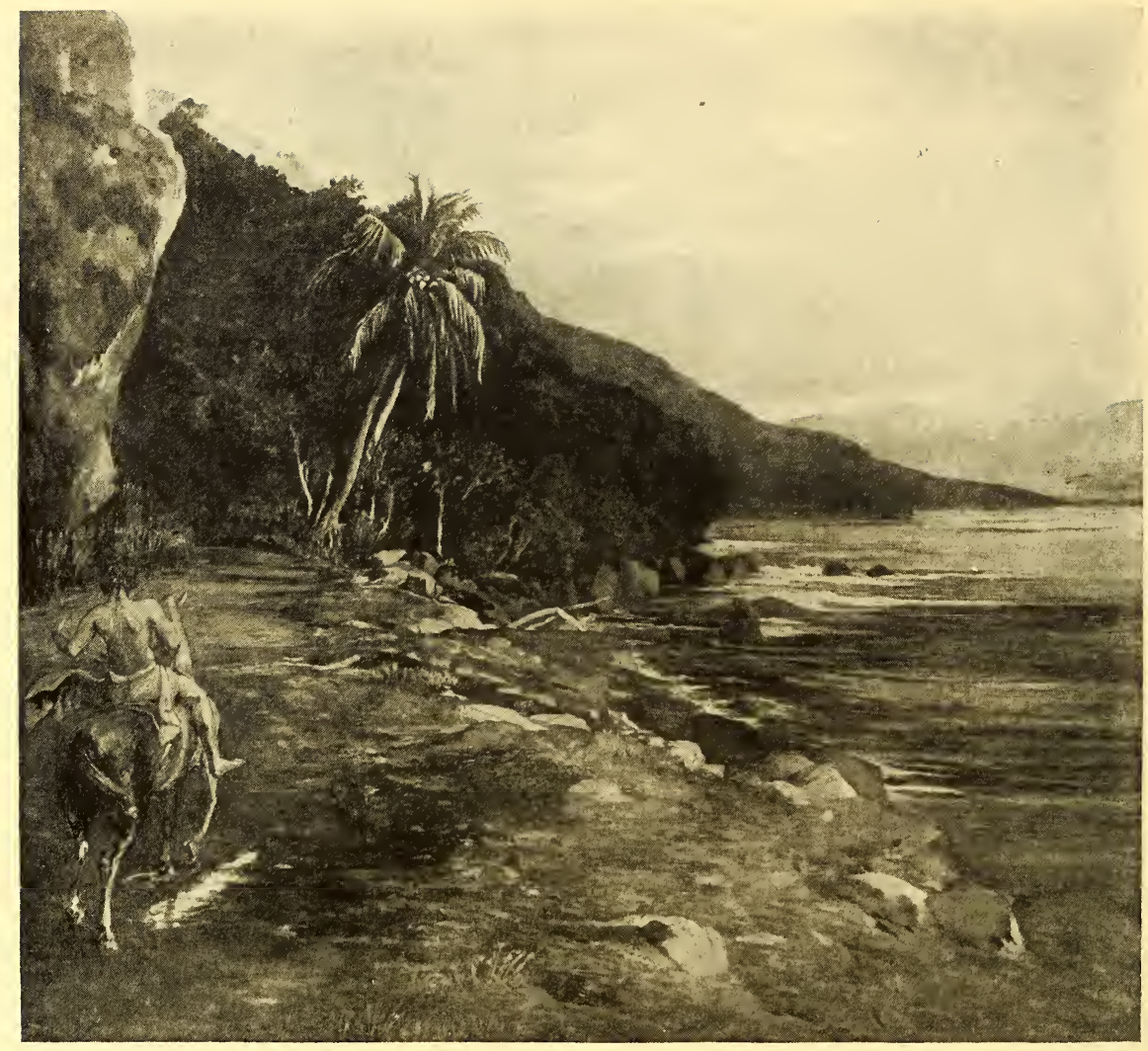

No. 116

\section{JOHN LA FARGE, N.A.}

American: 1835-1910

\section{BRIDLE PATH-TAHITI}

Water Color: Height, 19 inches; length, 201/2 inches

A virile piece of painting of a South Sea Island subject, characterized by strong color. A grassy roadway, bordering the sea, leads from the left foreground to a point where it disappears in the middle distance amid thick masses of foliage. A horse, with rider nude except for a red loin cloth, is seen in the extreme left foreground, in back view to the spectator. Beyond the hills which line the shore is an evening sky of great brilliancy. 
No. 117

\section{WINSLOW HOMER, N.A.}

Americhin : $1836-1910$

\section{SAILING OUT OF GLOUCESTER HARBOR}

Water Color: Height, 14 inches; length, 20 inches

A sLOop under full sail and careening to the right is seen making its way seaward, while a two-master is indicated on the horizon. The hull and sail of the sloop are reflected in the water, making a note of dark gray in an ensemble of clear tints, the sky being filled with white clouds and, in the upper portion, gray.

Signed at the lower left.

From Edward C. Stedman, New York, 1905.

No. 118

\section{WILLIAM GEDNEY BUNCE, N.A.}

American : $1840-1916$

\section{VENICE-MOONLIGHT}

Panel: Height, 24 inches; width, 16 inches

This picture presents an ensemble of qualified blues and grays, the sky occupying the greater portion of the composition. The moon is rising over the horizon and the Campanile, sailboats and lights on shore produce various accents of value.

Signed at the lower right. 
No. 119

\section{J. FRANCIS MURPHY, N.A.}

American: 1853 -

APPROACH TO THE OLD FARM

Height, 22 inches; width, 16 inches

A LANDSCAPE with a color scheme of warm greens and grays and yellow browns; a meadow and pathway in the foreground, some slender trees in the middle distance; farm buildings on the left, and rising ground beyond. Over all an autumn sky of gray.

Signed at the lower left, and dated 1902.

Frederick S. Gibbs Collection, New York, 1904, Catalogue No. 271. 


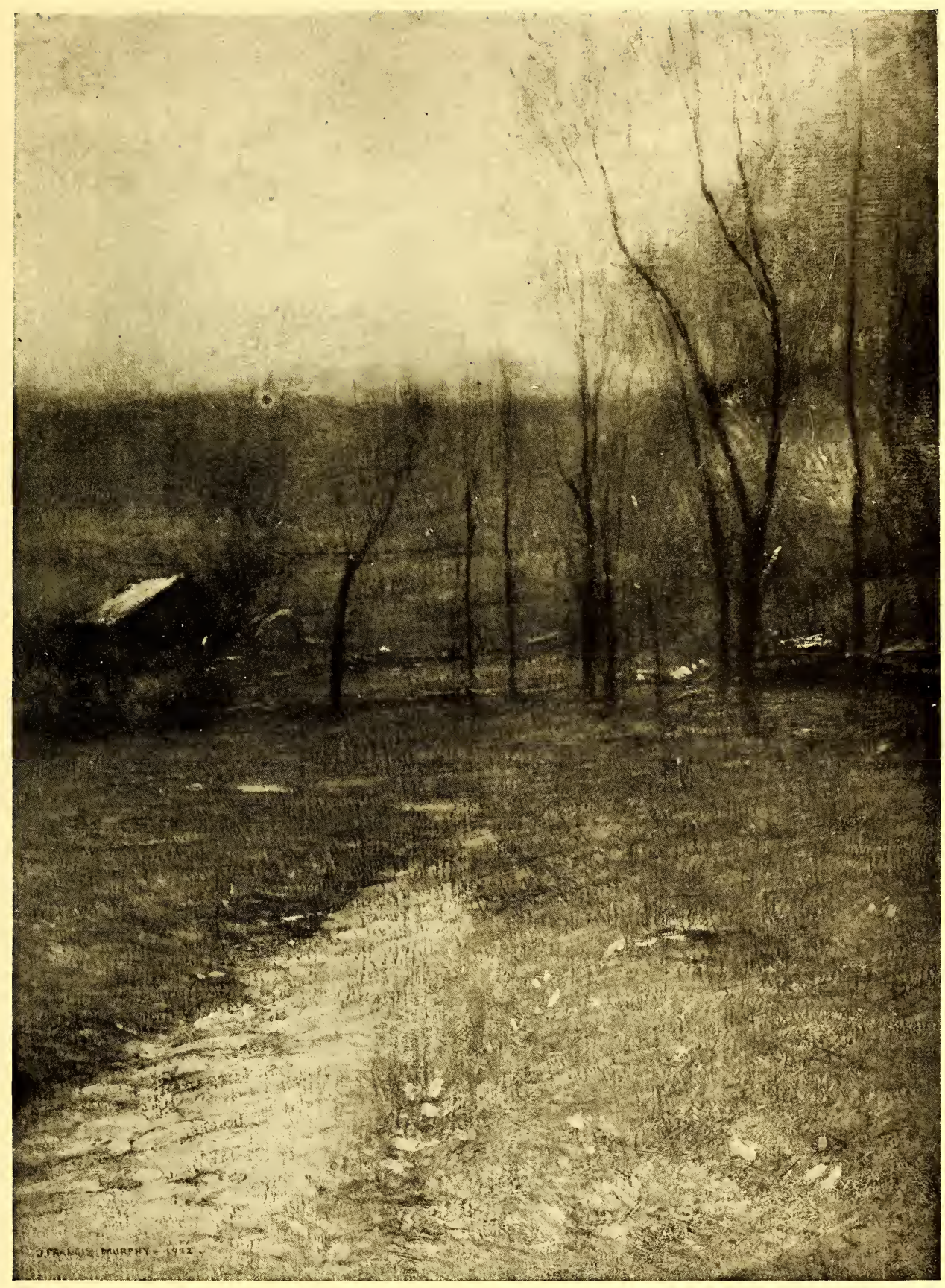




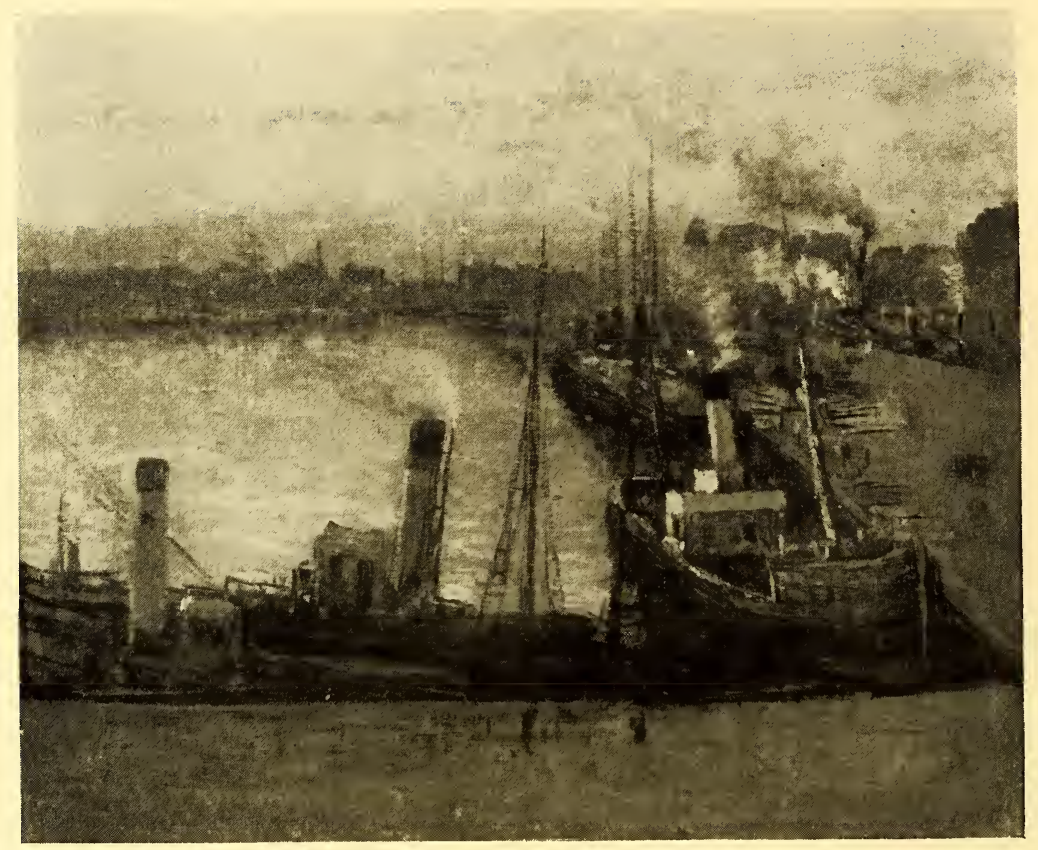

No. 120

\section{HENRY GOLDEN DEAR'TH, N.A.}

Americax: 1864-

\section{A GRAY DAY, BOULOGNE-SUR-MER}

Height, 18 inches; length, 22 inches

ONE of a series of pictures, by this artist, of harbors and shipping. In the forepart of the composition, in the basin of the port, are moored several tugs and farther off are other vessels. Smoke and steam arise from their funnels and pipes and the water reflects a sky of warm gray. Notes of green and red in the hulls diversify the sober scheme of color.

Signed at the lower right.

Purchased direct from the artist, New York, 1912. 
No. 121

\section{THEODORE ROBINSON}

American : $1854-1896$

\section{GATHERING PLUMS}

\section{Height, 22 inches; width, 18 inches}

A GIRL, with white apron and cap and yellow frock, stands on a step-ladder up among the foliage of plum trees. A little distance away is another girl, in white bodice and blue apron. The scene is in a French orchard and is depicted in sunlight effect with fresh, clear color.

Signed at the lower right, and dated 1891.

Purchased from S. S. Dustin, New York, 1908.

No. 122

\section{LOUIS PAUL DESSAR, N.A.}

American: $186 \%$ -

\section{MOONLIGHT}

Height, 18 inches; length, 24 inches

'THE composition shows a sheep stable with high sloping thatched roof, on the right, and a shepherd and his flock entering by a doorway in the plastered wall. By the side of a road, which leads into the middle of the picture, a cottage, on the left, shows a gleam of lamp-light from within in the cracks of the shutters. Overhead is a night sky with a few stars.

Signed at the lower right. 
No. 123

\section{HOMER D. MARTIN, N.A.}

American : $1836-1897$

\section{AUTUMN ON THE SUSQUEHANNA}

\section{Height, 15 inches; length, 25 inches}

A wELl-Known example of the earlier period of Homer Martin's landscape painting, characterized by conscientious study of detail. On an eminence in the foreground are three dead trees which, rising to the upper part of the canvas, form valuable dark notes in the pervading color harmony of autumn tints of red and tawny yellow. The river winds through the hills in the middle of the picture and the distance fades away to the horizon where it joins a sky of tender grays.

William T. Evans Collection, New York, 1900, Catalogue No. 226. 


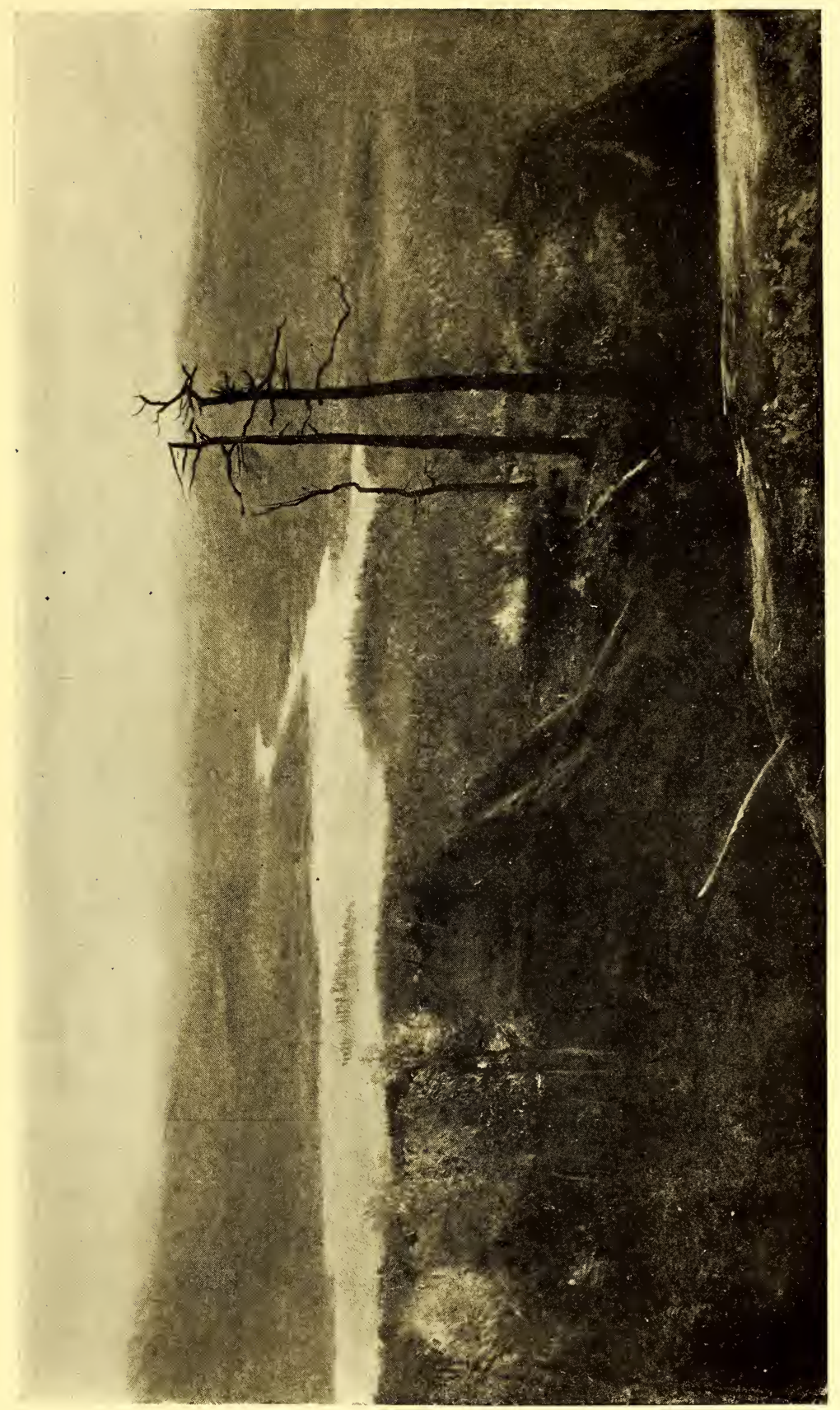


No. 124

\section{ALEXANDER H. WYAN'T, N.A.}

American : $1836-1892$

\section{NIGHTF ALL}

Height, 16 inches; length, 24 inches

The sun has set and night is coming on over a roadway, leading from the foreground into the middle of the picture, through stretches of green pastures. Groups of trees show their masses before a sky of gray clouds and on the horizon, toward the right, is the silhouette of the roof of a house.

Signed at the lower left.

William T. Evans Collection, New York, 1900, Catalogue No. 50. 


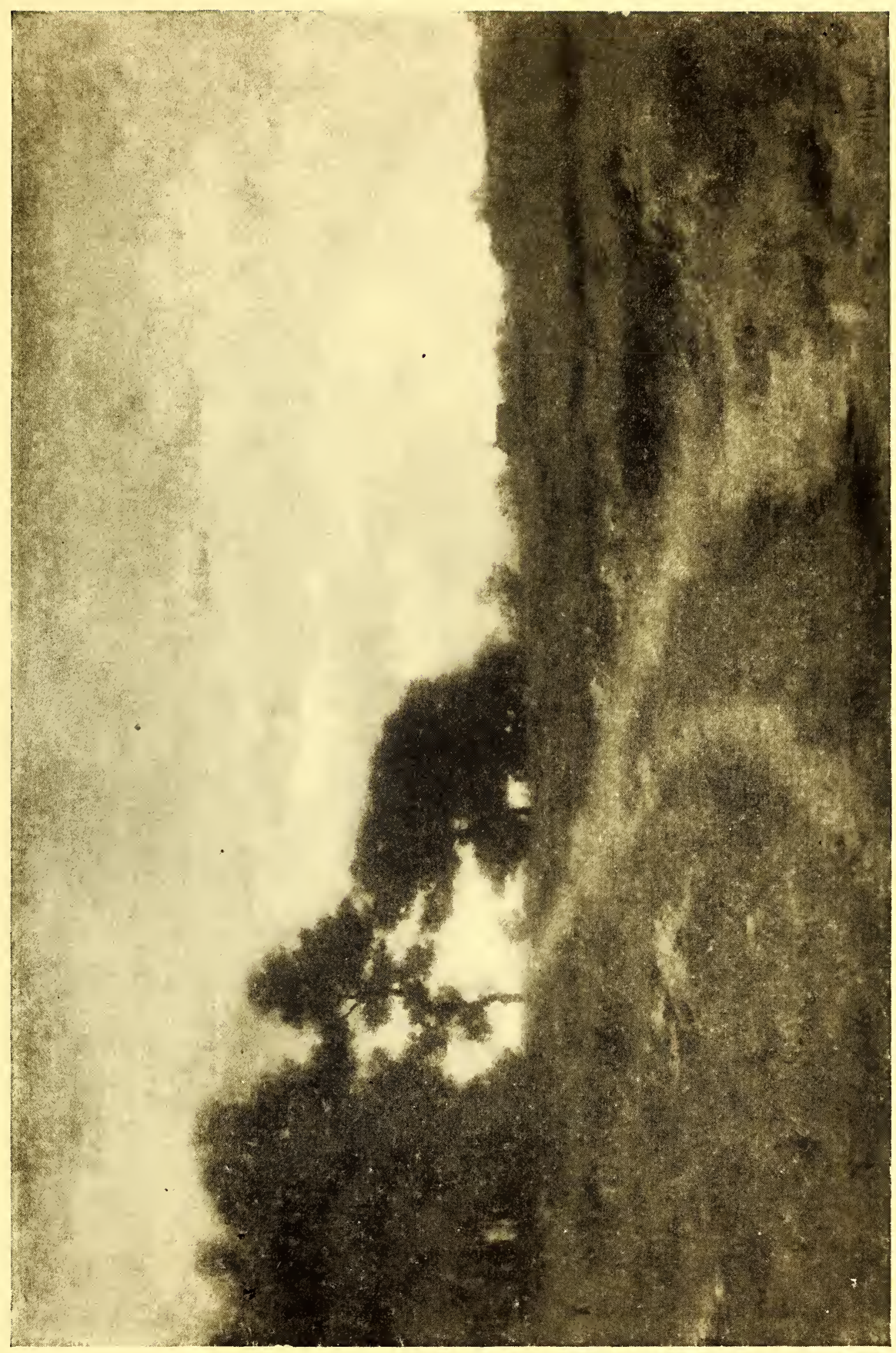


No. 125

\section{GEORGE FULLER, A.N.A. \\ American : 1822-1884}

\section{IDEAL HEAD}

Height, 231/2 inches; width, 193/4 inches

Emerging from a dark background is the face of a young woman in three-quarters view; lace-like drapery is indicated about her neck and shoulders, and the light falls from the left on the head and body.

Signed at the lower left.

Purchased from William Macbeth, New York, January 31, 1906, who purchased the painting from Walter Rowlands, 431 Boylston Street, Boston. 


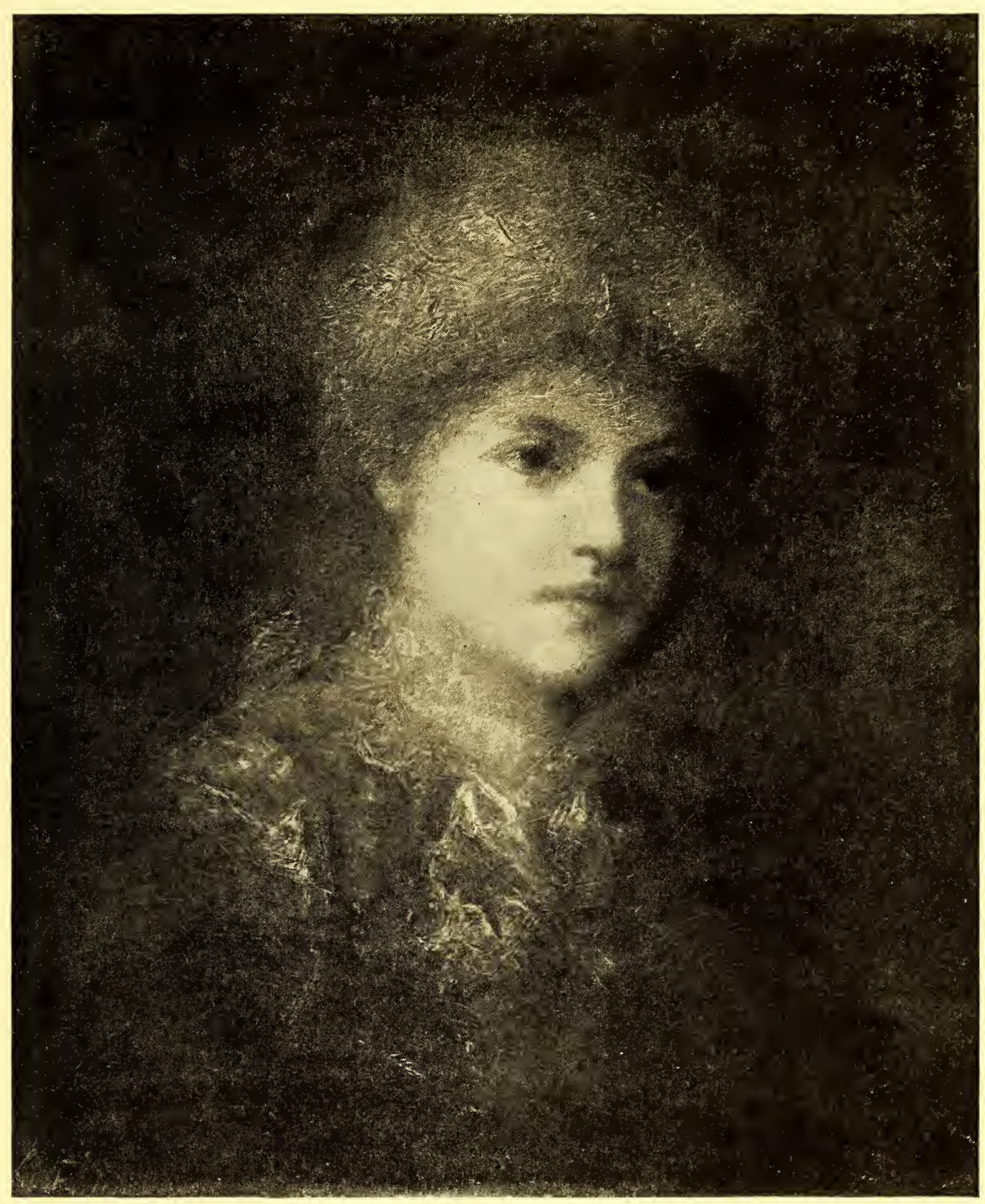


No. 126

\section{DWIGH'T WILLIAM TRYON, N.A. $x_{x} x$}

Anerican : 1849

\section{ACROSS THE FIELDS-NOVEMBER}

Panel: Height, 18 inches; length, 30 inches

Av autumn pastoral of New England country, with stony pastures in the foreground, dotted with bushes and trees. Farther away is another stretch of level ground and a belt of trees, with low-lying hills in the distance. The sky, of quiet grays, is tinged with blue at the horizon and gradated into warmer tones above.

Signed at the lower right.

From N. E. Montross, New York, 1904. 


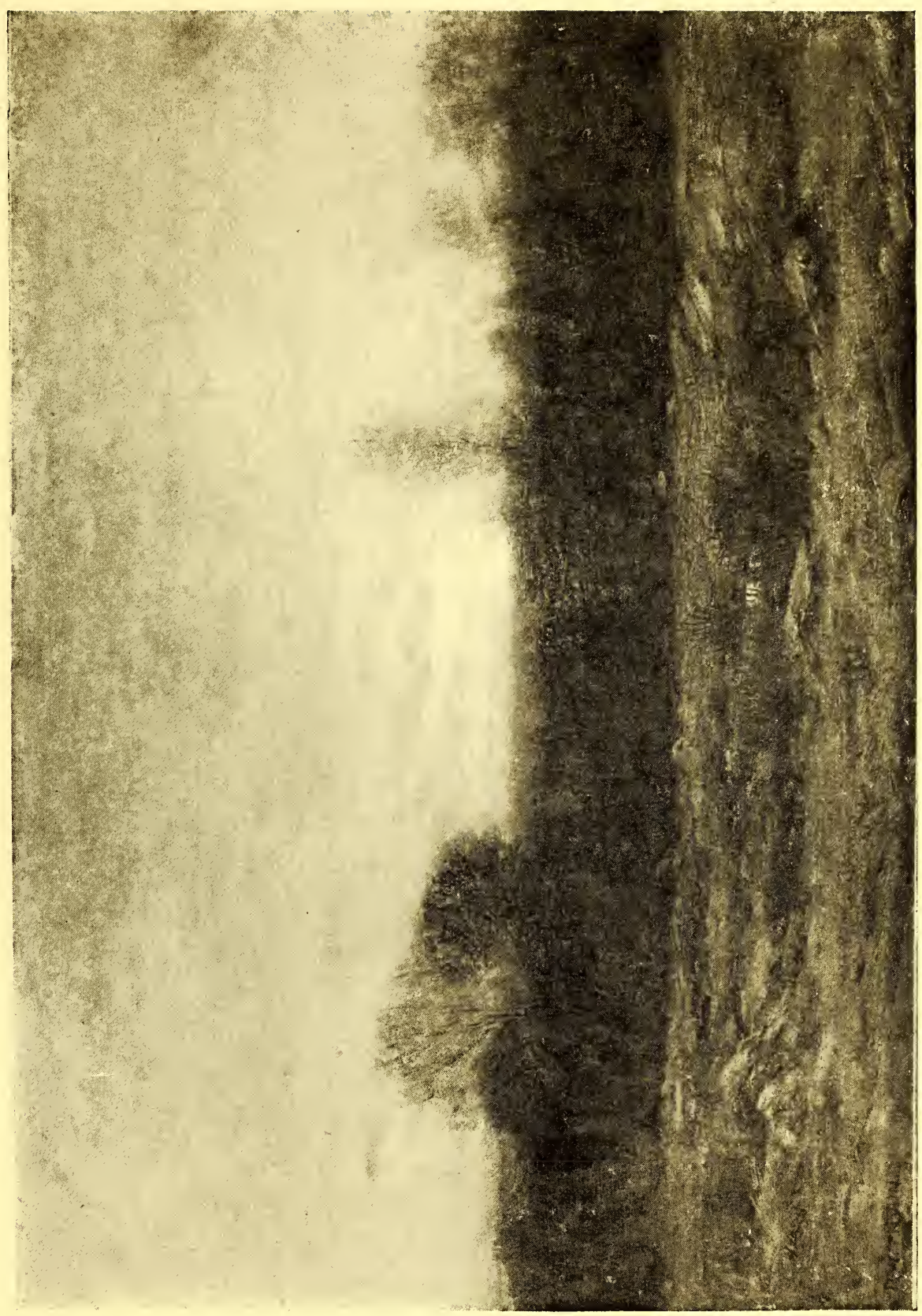


No. 127

\section{PAUL DOUGHERTY, N.A.}

American: $187 \%$ -

\section{EVENING AFTER THE RAIN}

Height, 20 inches; length, 30 inches

A BeLt of trees in autumn foliage, and in part without leafage at all, crosses the canvas in the middle distance, following the gentle slope of a hillside. At the base of the rising ground runs a stone fence and the foreground is composed of meadowland, with withered herbage, and a small stream. The sky with a curtain of gray cloud, tinged with pink on the lower edges, reveals below, on the left, a clear space filled with evening light.

Signed at the lower left, and dated 1903.

Purchased from William Macbeth, New York, 1903. 


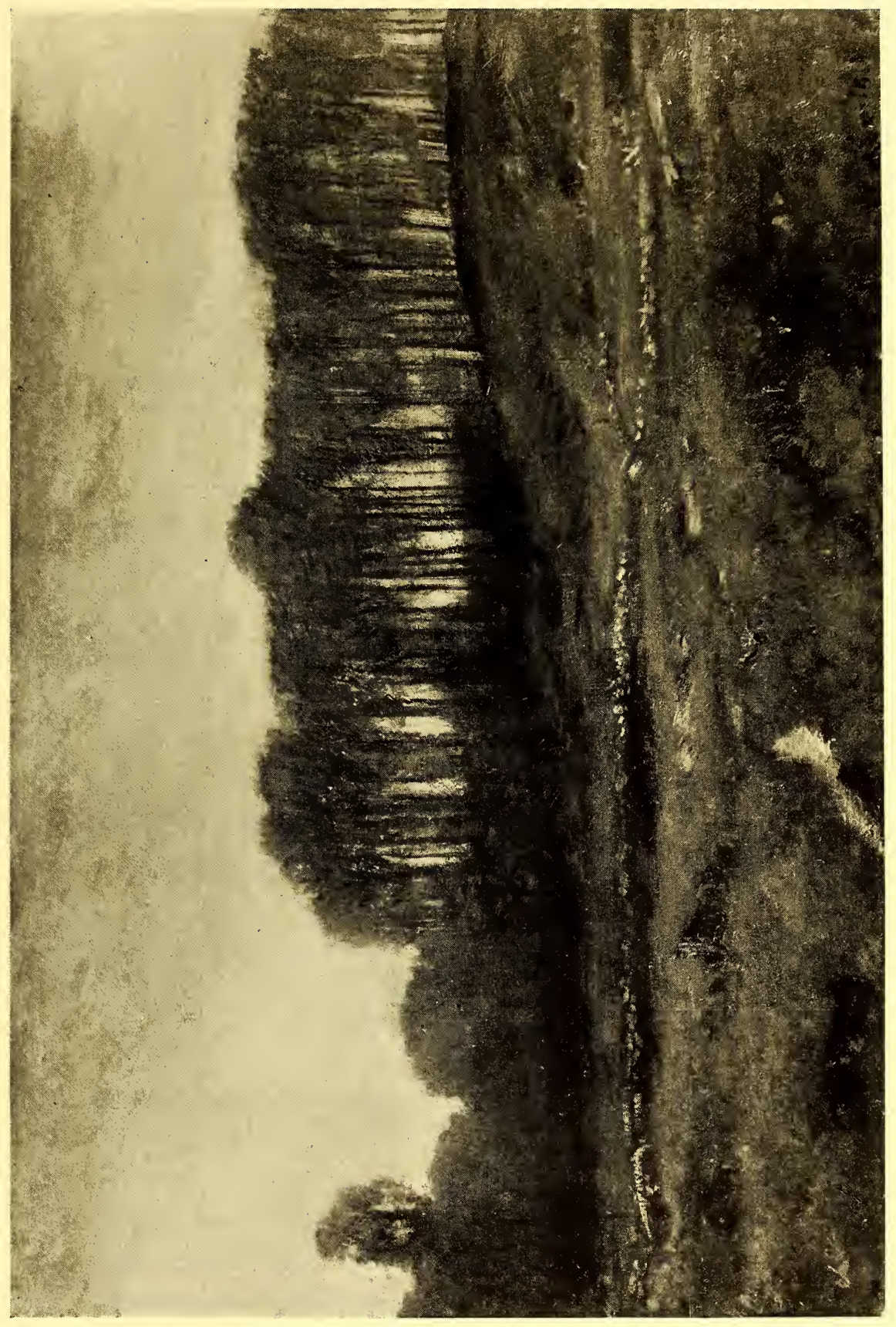




\section{GEORGE INNESS, N.A.}

AMERICAN: $1825-1894$

\section{NEAR MONTCLAIR}

Height, 19 inches; length, 283/4 inches

As unfinished picture, vigorously "laid in" and completely balanced in composition, values and general effect. A plain occupies the foreground and a white-walled cottage is seen at the right, in the middle distance. On the horizon, at the left, is a town. The sky shows broken masses of white and gray clouds with a space of blue in the left center.

Signed at the lower right.

No. 129

\section{WINSLOW HOMER, N.A.}

AJIERICAN : 1836-1910

\section{THE TURKEY BUZZARD}

Water Color: Height, 14 inches; length, 20 inches

A clump of palm trees, with rich green foliage and light gray trunks, forms the center of this brilliant piece of painting. A strip of sandy beach, the blue water of a lagoon, a belt of trees in the distance, dark under the shadow of a cloud, and a high sky of gray with a patch of blue in the upper left, complete the picture. High up on the right sails the turkey buzzard. The effect is rendered with the simplest of means, evincing admirable mastery of the medium, and delighting by sureness of accomplishment.

Signed at the lower left, and dated 1904.

Purchased from the artist, through the American Water Color Society, New York, 1906, Catalogue No. 442. 


\section{HENRY WARD RANGER, N.A.}

American : 1858-1916

\section{GOLDEN EVENING: NOANK HARBOR}

Height, 28 inches; length, 36 inches

A WELL-KNown picture, presenting a color harmony of warm tints. The lower part of the composition shows the expanse of the sea, with low horizon, dotted with a few sails on the extreme left. Ships and buildings are on the right, with two buoys in the immediate foreground. From the horizon to the top of the picture is a great expanse of evening sky in which broken clouds are gilded with orange, pink and yellow, the whole tempered by notes of blue.

Signed at the lower left, and dated 1905.

Purchased direct from the artist, New York, 1905.

No. 131

\section{JULIAN RIX}

Americhan: $1851-1903$

NORTHERN LAKE, NEW BRUNSWICK, CANADA

Height, 22 inches; length, 30 inches

THe waters of the lake occupy the lower part of the picture and reflect on rippling waves the warm yellow-white of sunkissed cumulus clouds in a sky of blue. Through the middle of the composition runs a belt of level country with a mountain rising from the plains on the right. 'The effect depicted is one of late afternoon.

Signed at the lower right, and dated 1899.

Purchased direct from the artist, New York, 1899. 
No. 132

\section{JOHN HENRY TWACHTMAN}

American : 1853-1902

\section{THE FROZEN BROOK}

Height, 30 inches; width, 22 inches

A winter landscape with snow-covered slopes and a brook in the middle portion of the canvas. In the upper part, through the trunks and branches of trees, is seen a stretch of country and a bit of gray sky.

Signed at the lower left.

From the J. H. Twachtman Sale, New York, 1903, Catalogue No. 41. 


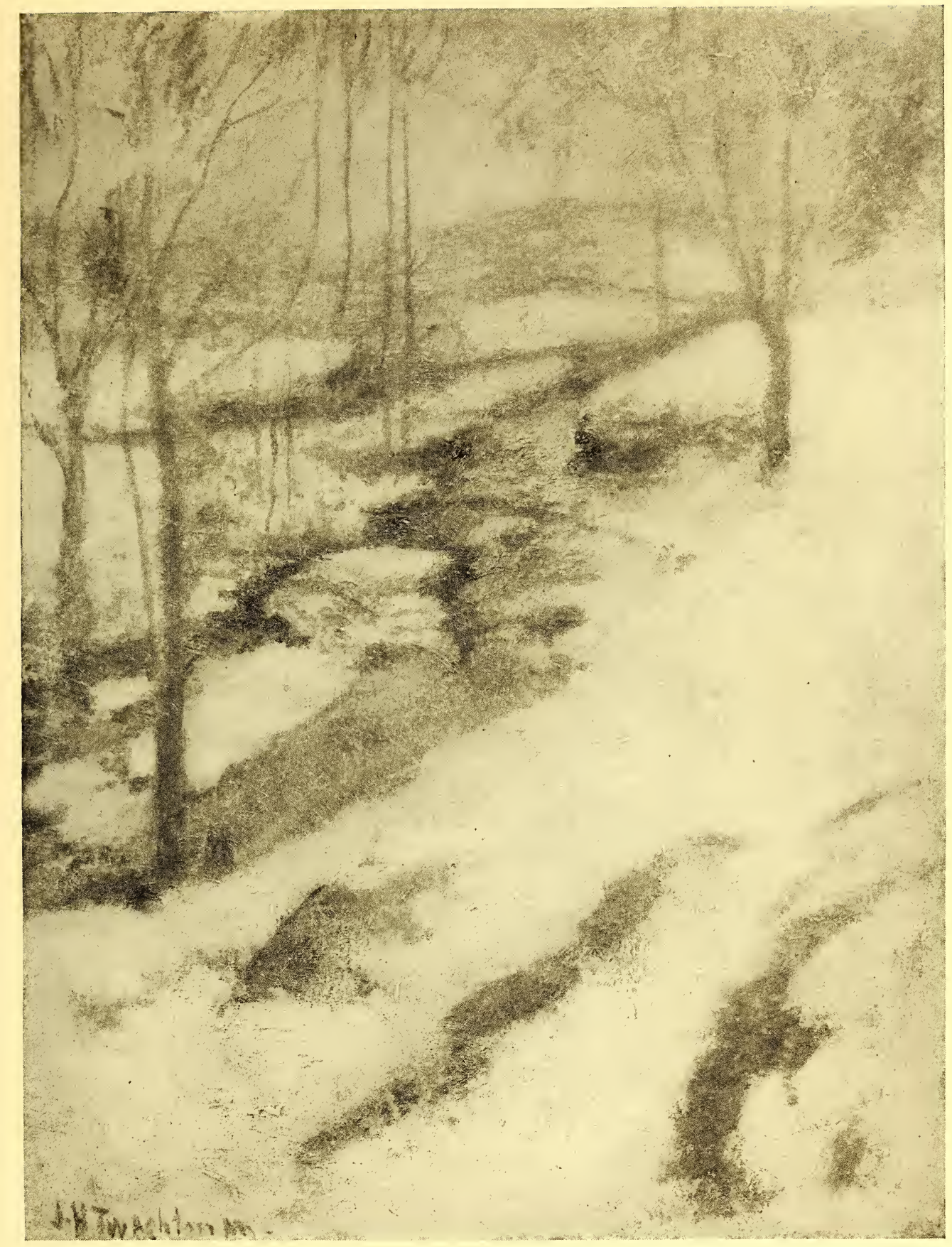


No. 133

\section{WINSLOW HOMER, N.A. $\quad x \times x$}

American : $1836-1910$

\section{A VOICE FROM THE CLIFFS}

Water Color: Height, 21 inches; length, 30 inches

This is one of the most celebrated of all of Winslow Homer's figure pictures, and belongs to the series which he painted from English motives in the early eighties. It has been described and praised by many writers. The composition shows a group of three fisher-girls, with their baskets and nets, standing in three-quarter length in the immediate foreground, the group relieved against a background of chalky cliffs. At the lower right, on the surface of an estuary, is a small sail-boat, and on the extreme left, behind the group of figures, is a dory drawn up on shore. The three young women, whose figures face the spectator, are looking intently forward to the right. Their expressions show intentness on whatever is happening on the sea which lies beyond.

Signed at the lower right, and dated 1883.

Purchased from Edward C. Stedman's Collection, New York, 1905. 


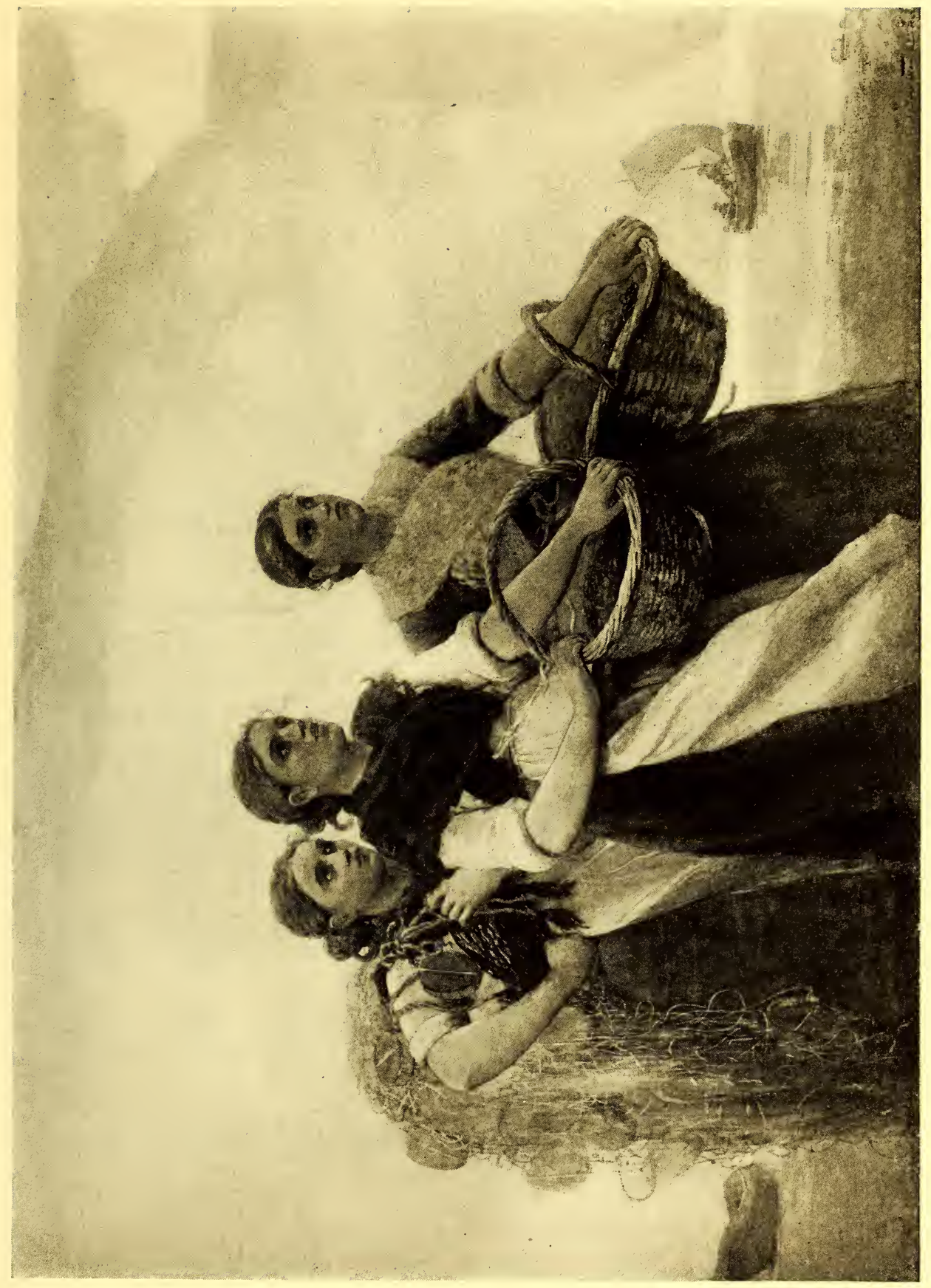


No. 134

\section{PAUL DOUGHERTY, N.A.}

American : 1877 -

\section{GOLD AND GLOOM}

Height, 25 inches; length, 30 inches

A Headland jutting out into the sea, in the middle distance on the right, and appearing in the picture quite dark against the sky of clouds tinged with evening light, furnishes a sombre mass in contrast to lighter masses, and explains the title. In the immediate foreground on the left is a bit of shore. The waters between this and the headland and in the view of the sea beyond are depicted in tints of varied blues, grays and whites.

Signed at the lower left.

Purchased from William Macbeth, New York, 1905. 


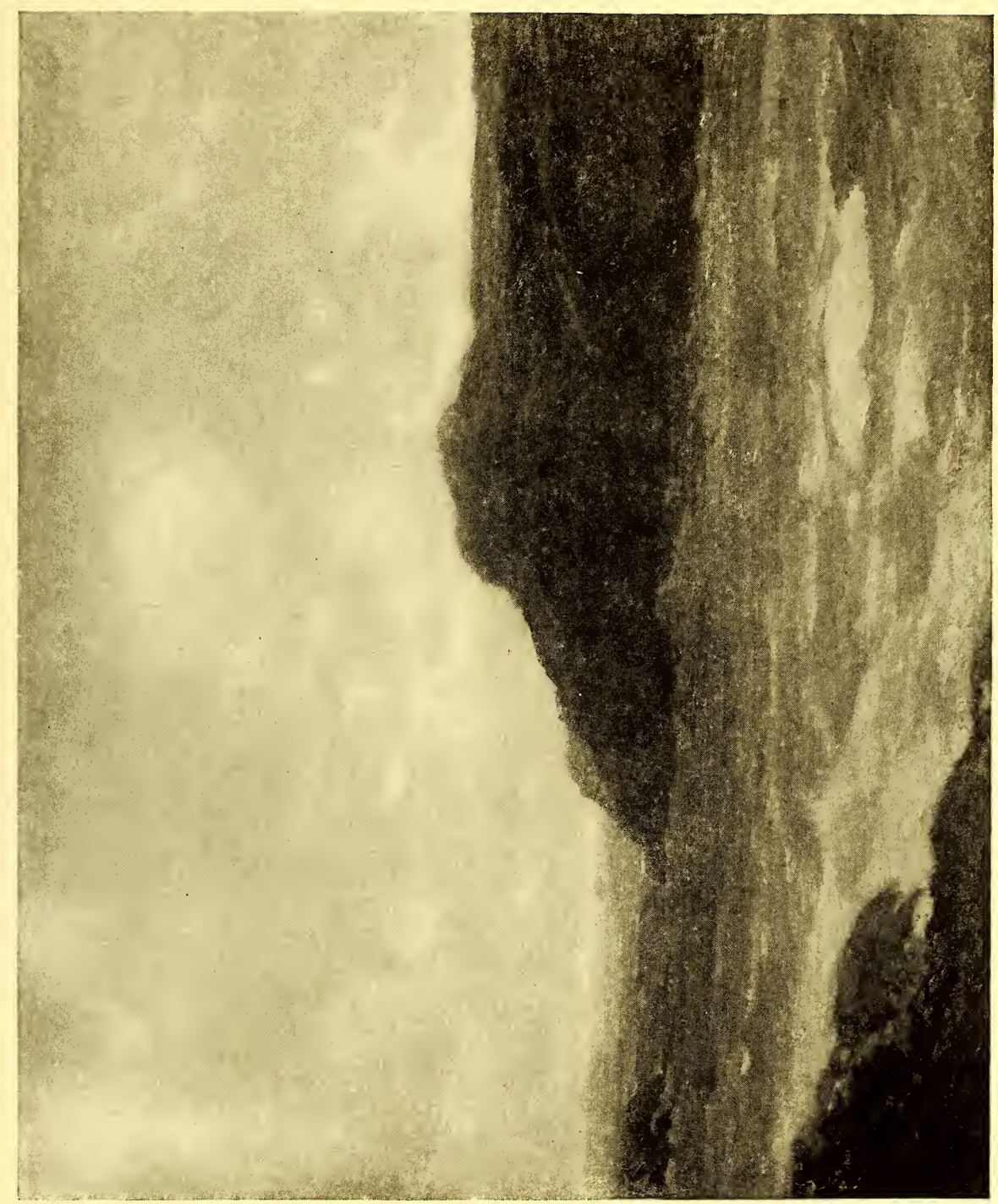


No. 135

\section{GEORGE IN NESS, N.A.}

American : 1825-1894

\section{RETURNING FROM PASTURE-MILTON}

\section{Panel: Height, 22 inches; length, 34 inches}

GreEn pastures and, on the right, groups of trees in summer foliage, with a sky of subtle gray and white and a bit of blue, are the elements of this characteristic Inness landscape. On the left, in the foreground, two cows, wending their way homeward, form notes of light tints in the prevailing sober harmony.

Signed at the lower right, and dated 1880.

William T. Erans Collection, New York, 1900, Catalogue No. 114. 


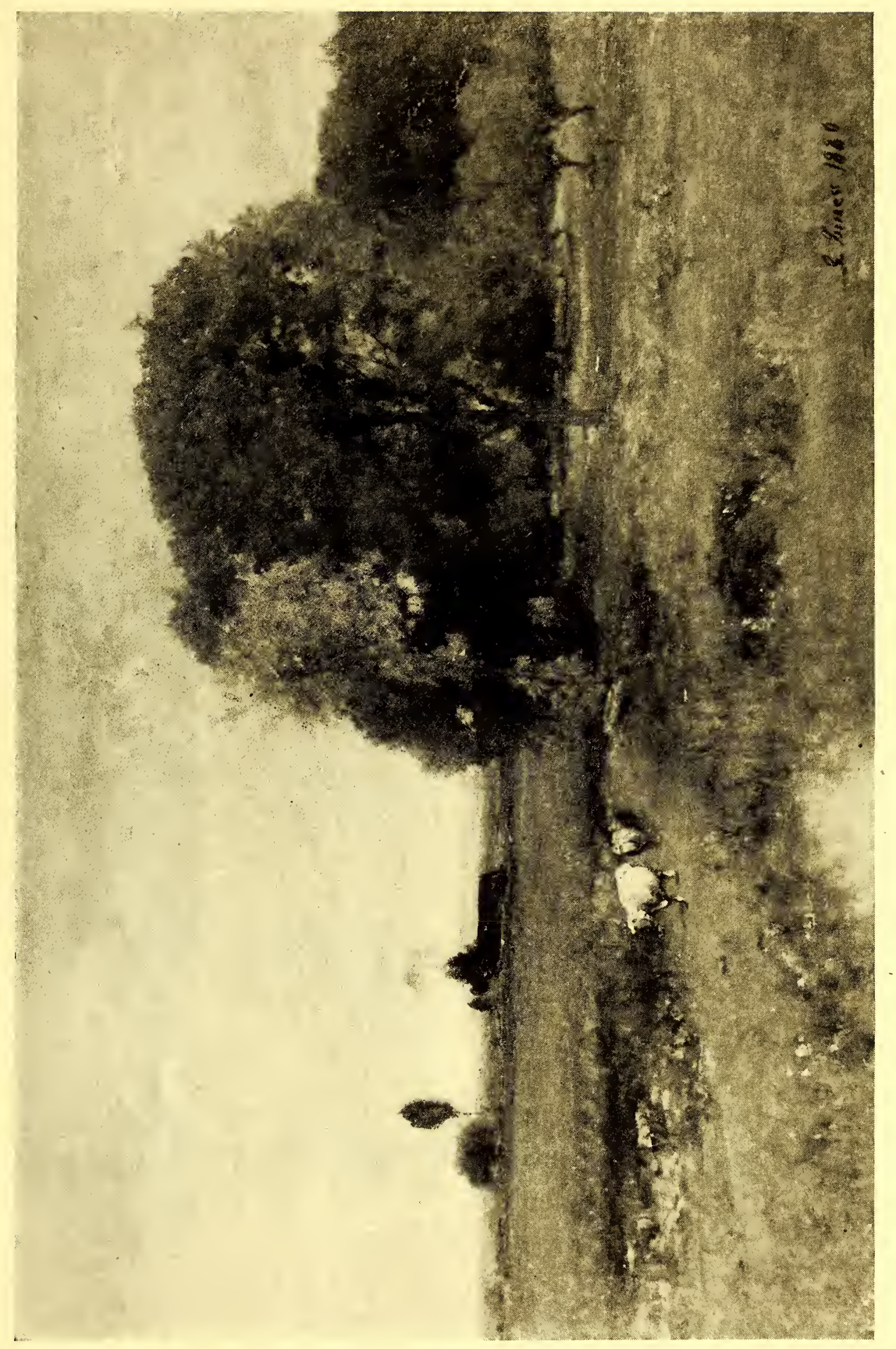


No. 136

\title{
ALEXANDER H. WYAN'T, N.A.
}

\author{
Americhe : 1836-1892
}

\section{THE DAWN}

Height, 22 inches; length, 30 inches

A LANDScape composed of the simple elements of meadows, in the foreground, with a pool and a group of trees on the left. The gray autmnal sky shows clouds tinged with the coming light of day and spaces of subdued blue in the upper portion.

Signed at the lower left.

From William Macbeth, and purchased by him from Mrs. Wyant in 1899. 


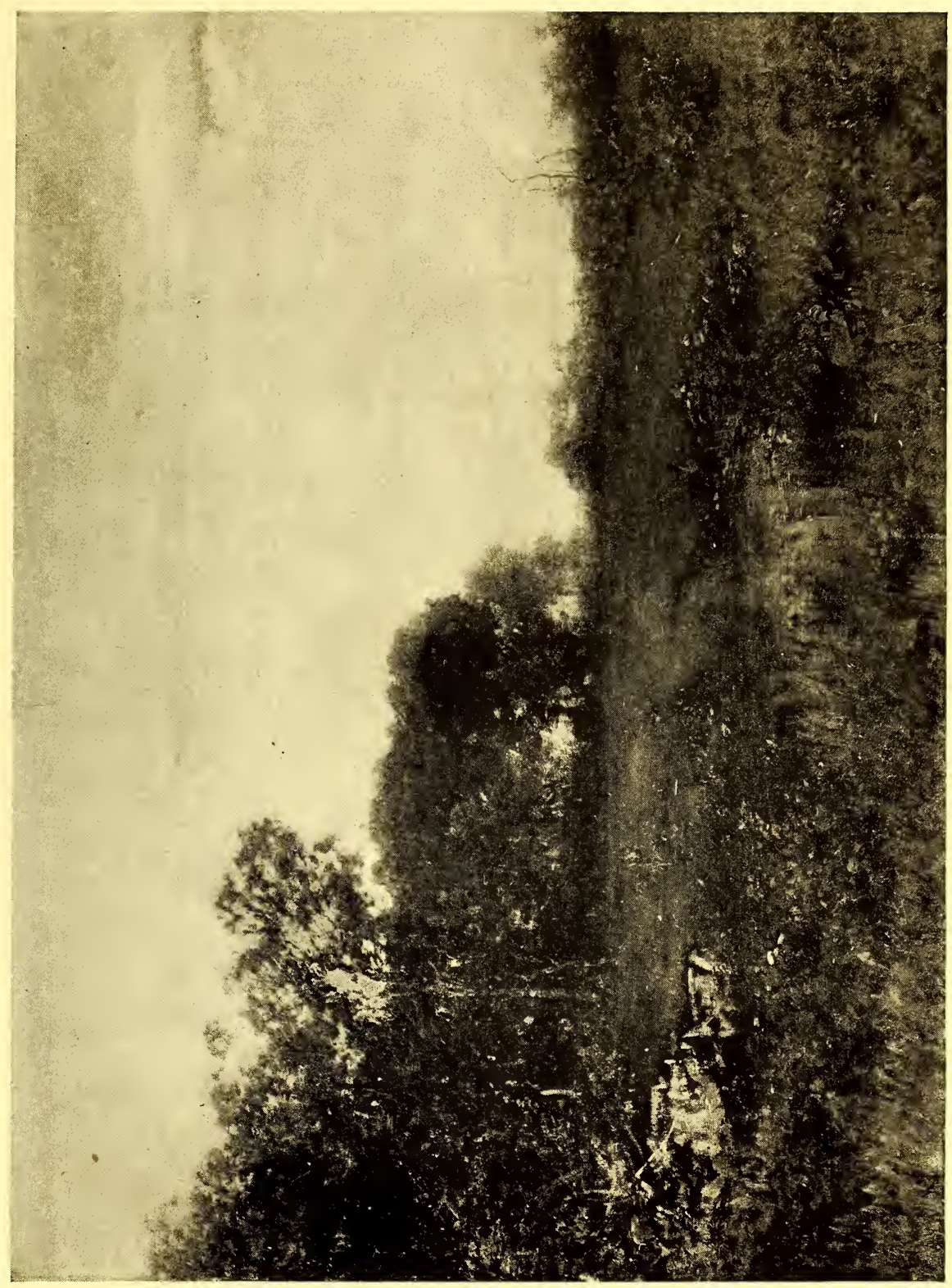


No. 137

\section{J. FRANCIS MURPHY, N.A.}

American : 1853-

\section{AFTERGLOW-OCTOBER}

Height, 24 inches; length, 33 inches

A Landscape composed of simple elements, a level stretch of country, bordered by masses of trees which extend across the canvas, occupying the foreground. Beyond is rising ground, and the sky, overhead, shows pale tints of pink and yellow intermingled with white and tempered blue. The effect is in the autumn, with the foliage illumined in part by reflected sunshine coming from the left and producing a glow of red and yellow. This is in contrast with the notes of green in the foreground and the whole is suffused with the October haze.

Signed at the lower left, and dated 1905.

Purchased from William Macbeth, New York, 1905. 


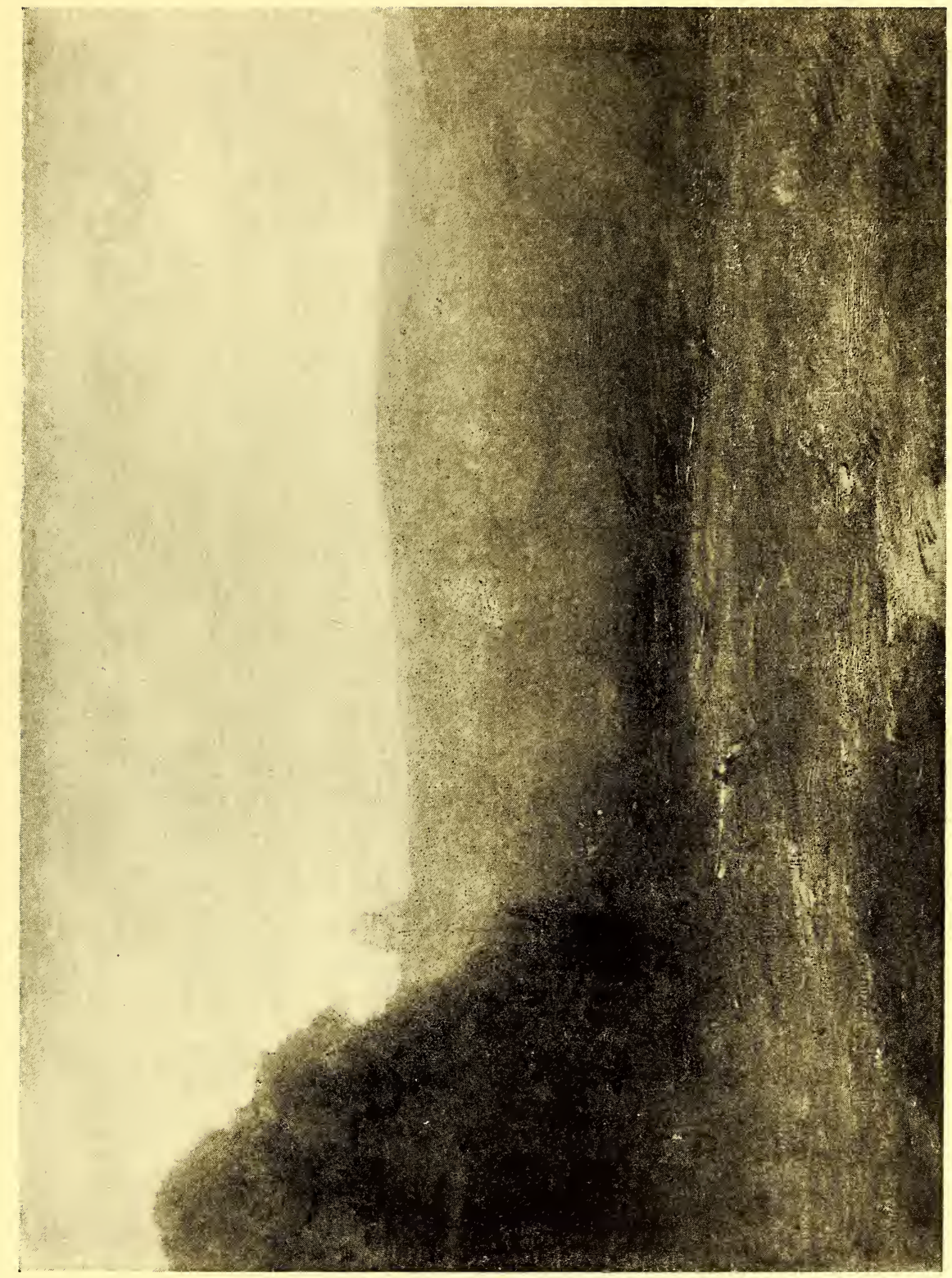


No. 138

\section{HENRY WARD RANGER, N.A. \\ American : 1858-1916}

\section{CLEARING FIRES}

Height, 28 inches; length, 36 inches

A Rough road leads from the middle foreground through a a piece of land that has recently been stripped of its timber, stumps and piles of cordwood appearing here and there, while in the distance brushwood fires are burning, with blue-gray smoke rising in the air. On either side of the road are a few trees, which have been spared, their tall trunks reaching to the upper part of the picture where their branches are covered with foliage in autumn tints. Beyond is a wide expanse of pearly gray sky with some spaces of blue.

Signed at the lower left, and dated 1909.

Purchased direct from the artist. 


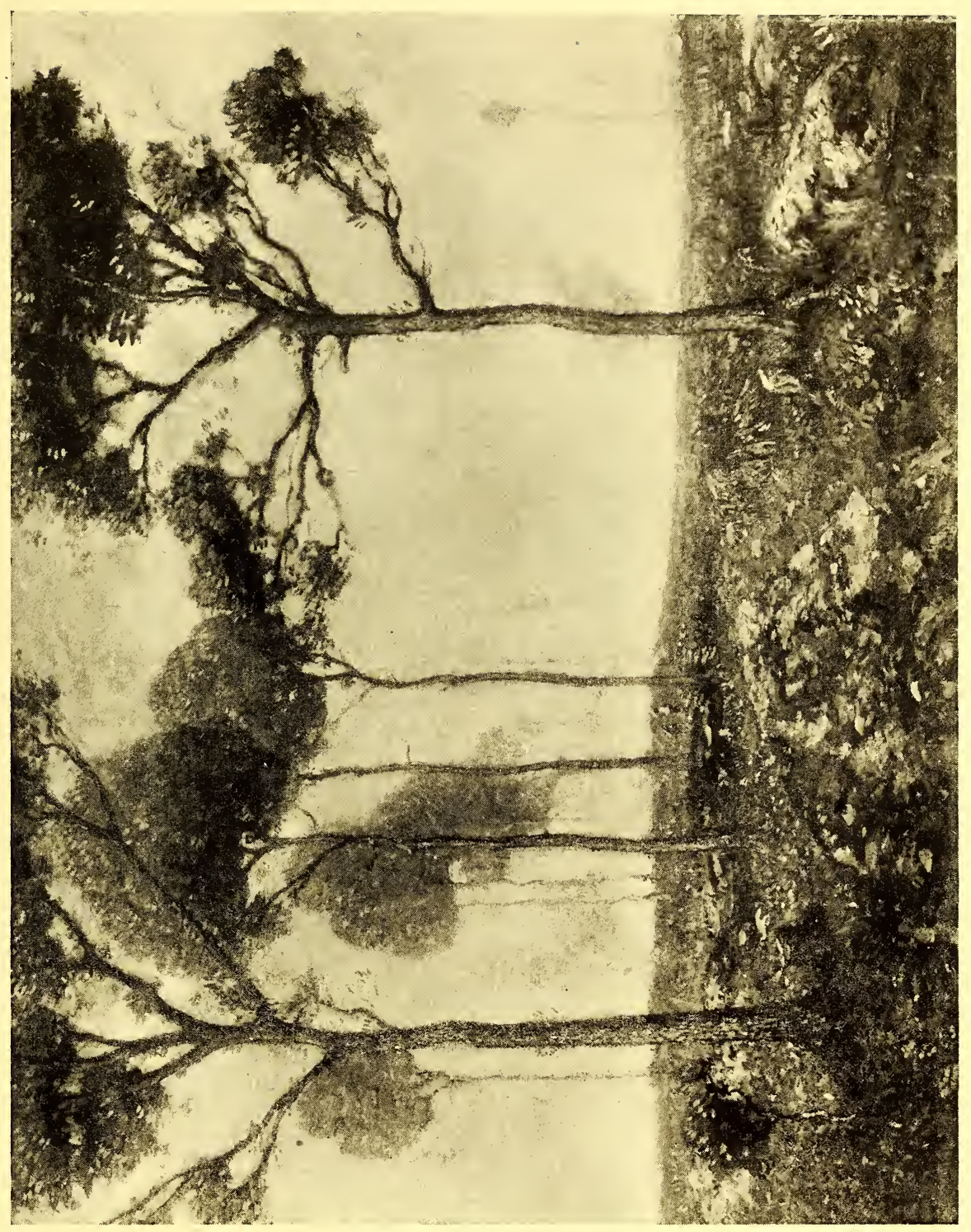


No. 139

\title{
LOUIS PAUL DESSAR, N.A.
}

American : 1867 -

\section{HAULING THE WINTER'S WOOD}

\author{
Height, 18 inches; length, 36 inches
}

THE central point of interest, giving the picture its title, is a sled, piled high with tree trunks and drawn by a double team of oxen, moving slowly away from the spectator as it is hauled over a stretch of snow-covered country. Two men, on foot, accompany the load and, above the horizon, bright notes of red and yellow in the sky indicate the setting of the winter sun.

Signed at the lower right, and dated 1904.

Purchased direct from the artist, New York, 1905. 


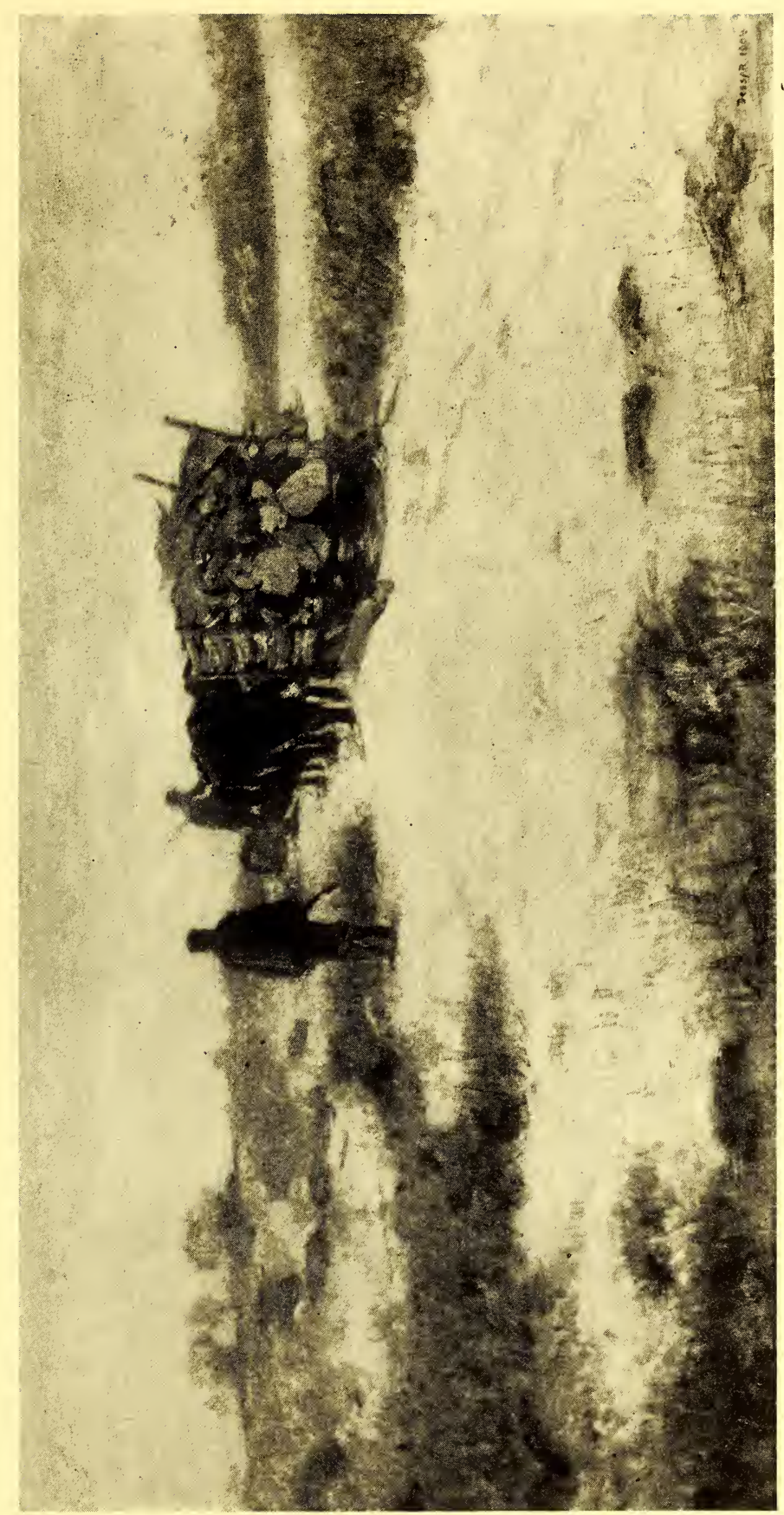


No. 140

\section{CHARLES HAROLD DAVIS, N.A.}

American : 1856 -

\section{THE AWAKENING OF SPRING}

Height, 24 inches; length, 36 inches

A Picture of rolling, rocky pastures with trees dotting a ravine in the middle distance and extending to the sea, where the blue waters are seen through a misty April atmosphere. The sky shows the tempered, rain-washed blue of the spring season and white clouds float above the horizon.

Signed at the lower left.

Purchased from the late T'heo. C. Noé, New York, March, 1904. 


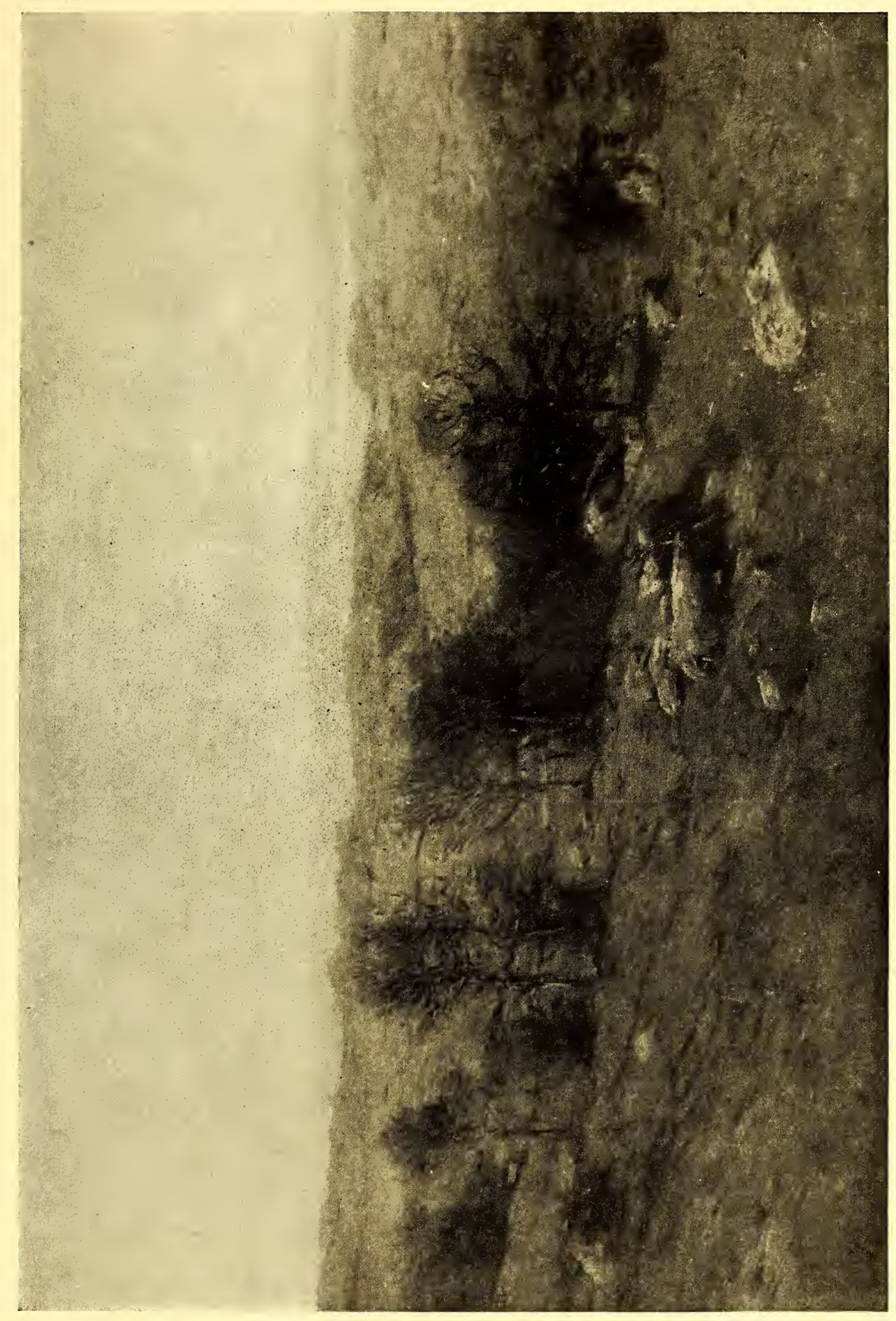


No. 141

\section{HENRY WARD RANGER, N.A.}

American : 1858-1916

\section{CLOUD AND SUNSHINE: NEAR AN OLD QUARRY, NEW ENGLAND}

Height, 28 inches; length, 36 inches

A GROUP of oaks, meadowlands and a pool are the features of the foreground in this landscape. In the distance appear a white spire and other indications of a village embowered in trees. From a horizon, placed somewhat low, rises a sky filled with broken cloud forms, warm tinted with pink and yellow, while on the extreme left rain is descending from a dark cloud high up in the picture. The pool reflects, with a valuable note of color, a space of blue in the sky.

Signed at the lower left, and dated '96. 


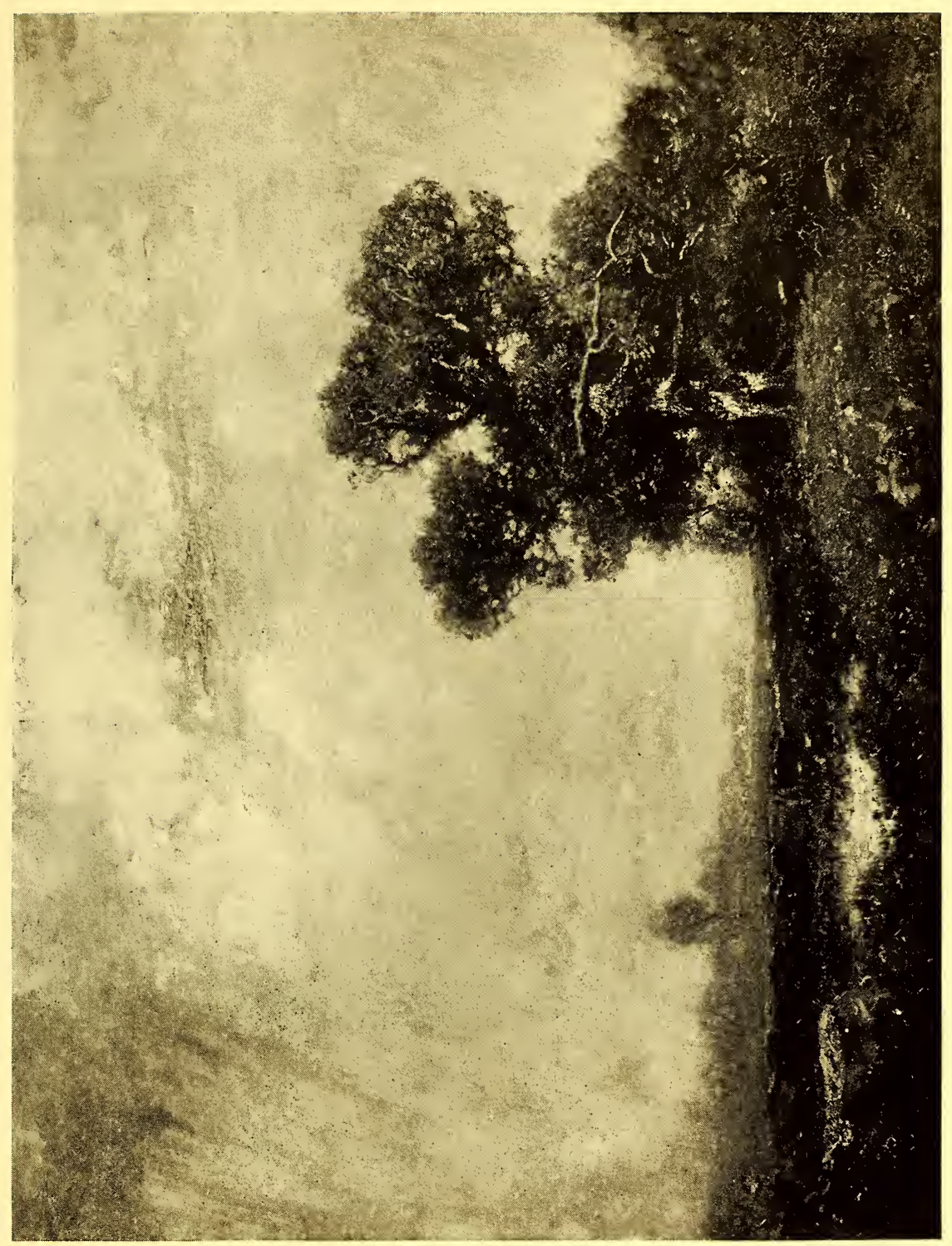




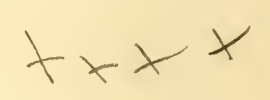

No. 142

\section{JOHN HENRY TW ACH'TMAN}

American : 1853-1902

\section{RAPIDS IN THE YELLOWSTONE}

30 inches square

A color arrangement in high-keyed tints, the motive being the waters of the Yellowstone flowing rapidly between rocky banks, which rise to white peaks in the upper portion of the canvas. The prevailing tints are qualified whites, pinks and blues, with a suggestion of violet, with more positive notes given in the blue and green of the water and the blue in a space of sky.

Stamp of the "Twachtman Sale" at the lower left.

Purchased from Silas S. Dustin, New York, 1908. 


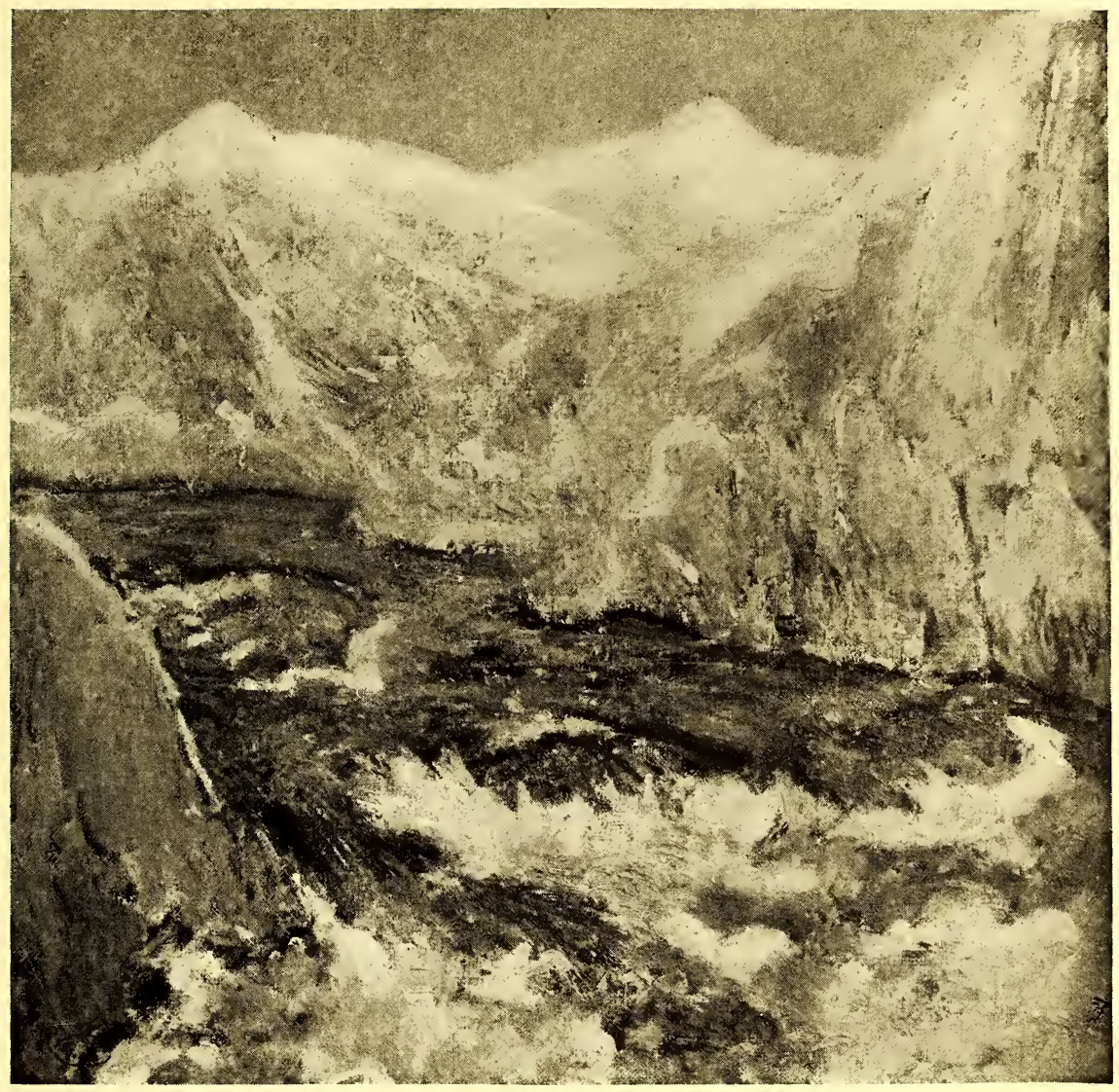


No. 143

\section{HORATIO WALKER, N.A.}

American: 1858-

\section{GIRL FEEDING TURKEYS}

\section{Height, 28 inches; length, 36 inches}

A Flock of turkeys, including a fine bronze gobbler and others of both the gray and buff variety, are grouped in the foreground, picking up grain. A farm-girl, in jacket of red and grayish-white apron, is standing near by leaning against a pile of cord-wood in the shade of trees, at the left of the picture. On the right is a cottage with its garden fence and a strip of country beyond.

Signed at the lower right, and dated 1904.

Purchased from N. E. Montross, New York, 1904. 


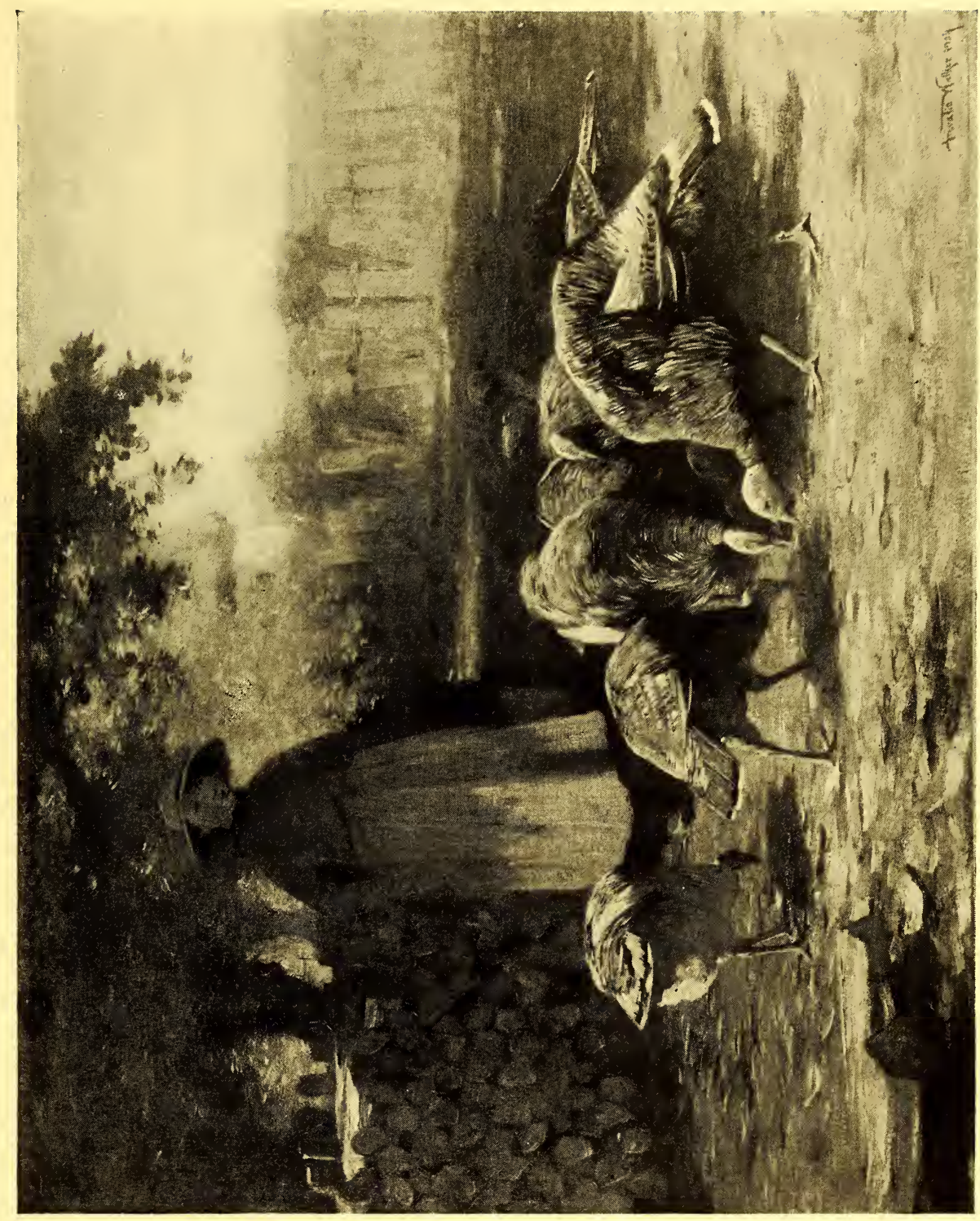


No. 144

\title{
ALEXANDER H. WYANT, N.A.
}

\author{
Americhn : $1836-1892$
}

\section{KEENE VALLEY}

\section{Height, 35 inches; width, 28 inches}

A Wrant of superior quality and subtle charm. While the middle distance, showing the wooded valley, mountain tops beyond, and the sky, seen through the tree trunks that reach up from the foreground to the top of the canvas, are carried about as far in the painting as was the famous artist's habit in completing a picture, parts of the foreground and of the foliage are less finished. But, taken as a whole, the canvas is distinctly unified and lacks nothing in completeness of general effect. The foreground, with a brook tumbling over its rocky bed and spreading out in a pool below, is in shadow. Beyond, all is lit up by the sun in a hazy sky.

Signed at the lower left.

Purchased from Mrs. A. H. Wyant, widow of the artist, New York, 1902. 


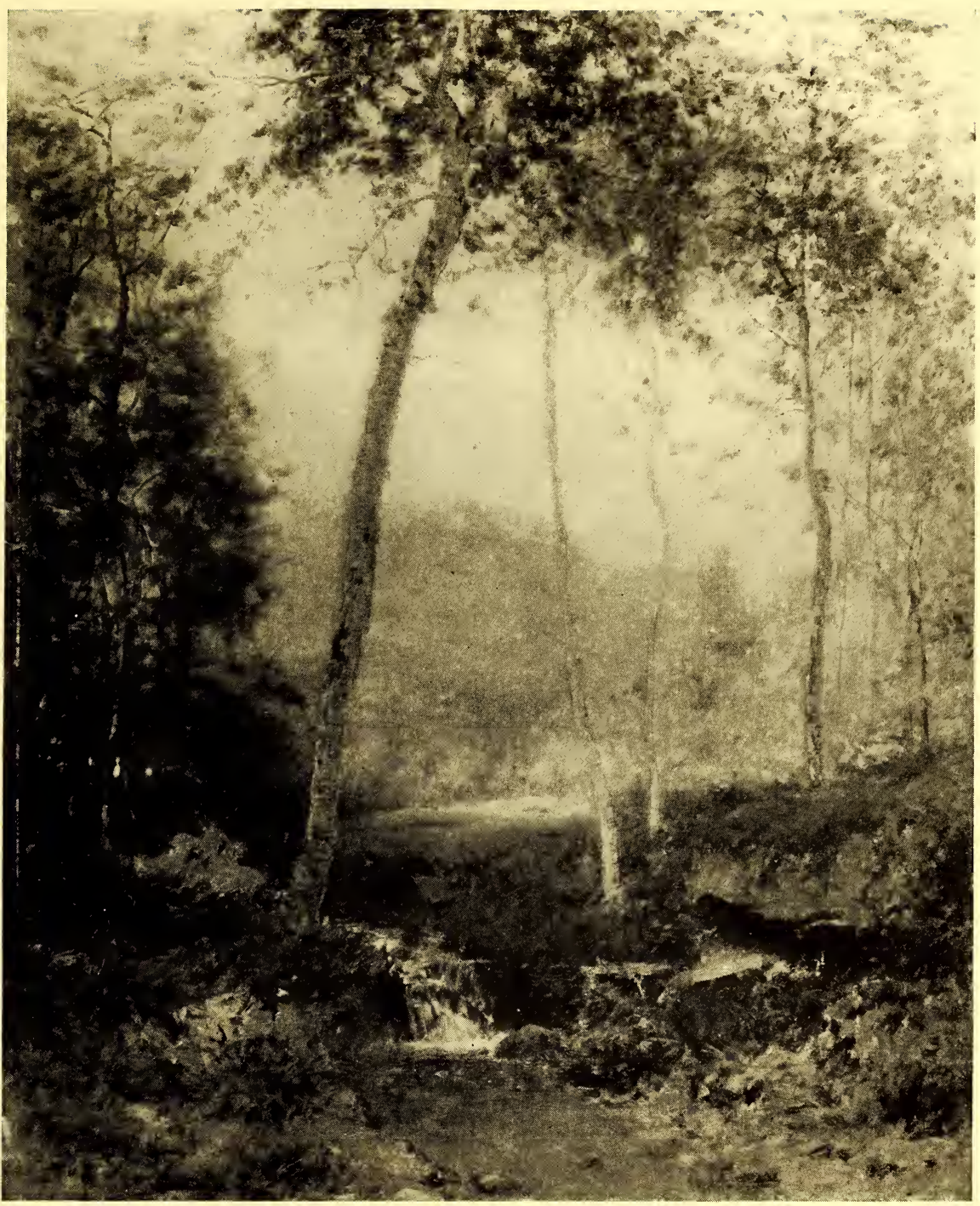


No. 145

\section{LOUIS PAUL DESSAR, N.A.}

American : 186\%-

\section{CHANGING PASTURE-OCTOBER}

\section{Height, 28 inches; length, 36 inches}

Here, in a clear space in the woods, a flock of sheep is seen advancing, the shepherd walking behind them, with the sun lighting up the middle part of the composition. Bowlders lie in shadow in the foreground and, on the left and right, the trunks of sturdy oaks furnish notes of gray amid the masses of crimson and yellow foliage. A glimpse of sky, with notes of blue and white, gives an additional contrast. A subdued pearly quality runs through the entire color rendering, softening the strong tints of the American autumn.

Signed at the lower right, and dated 1912.

Purchased direct from the artist. 


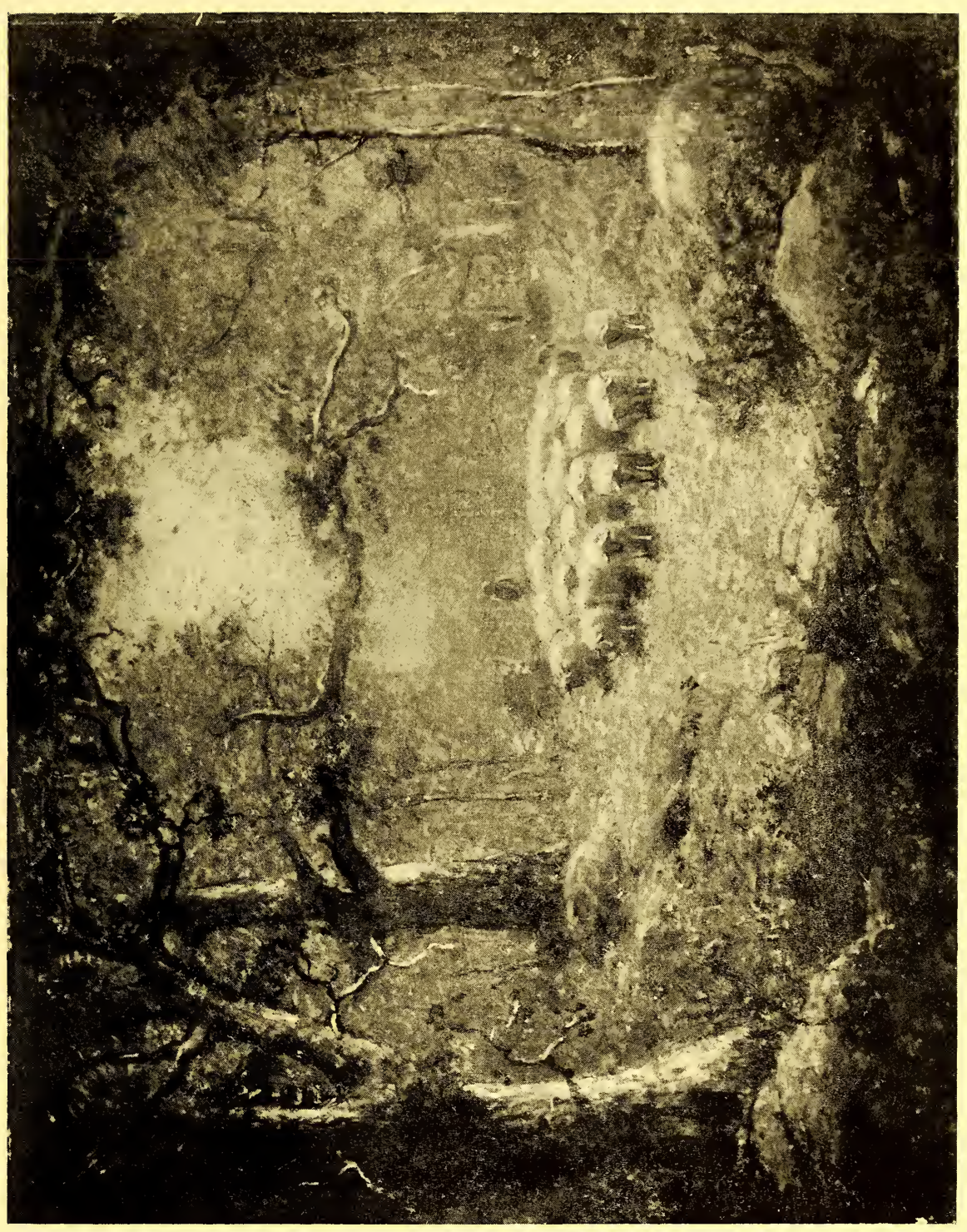


No. 146

\section{GEORGE INNESS, JR., N.A.}

Amelican : 1854-

\section{ON THE SAINTE-CROIX RIVER, CANADA}

Height, 26 inches; length, 361/2 inches

A landscape with a powerful effect of sunlight, coming from the right. A broad road leads through the middle of the foreground to the river, with low hills on the shore and a mass of cloud in the middle portion of the sky receives the sunlight and glistens with a glowing yellow tint. In the roadway are a flock of sheep and a shepherd and a white house is seen near by.

Signed at the lower left. 


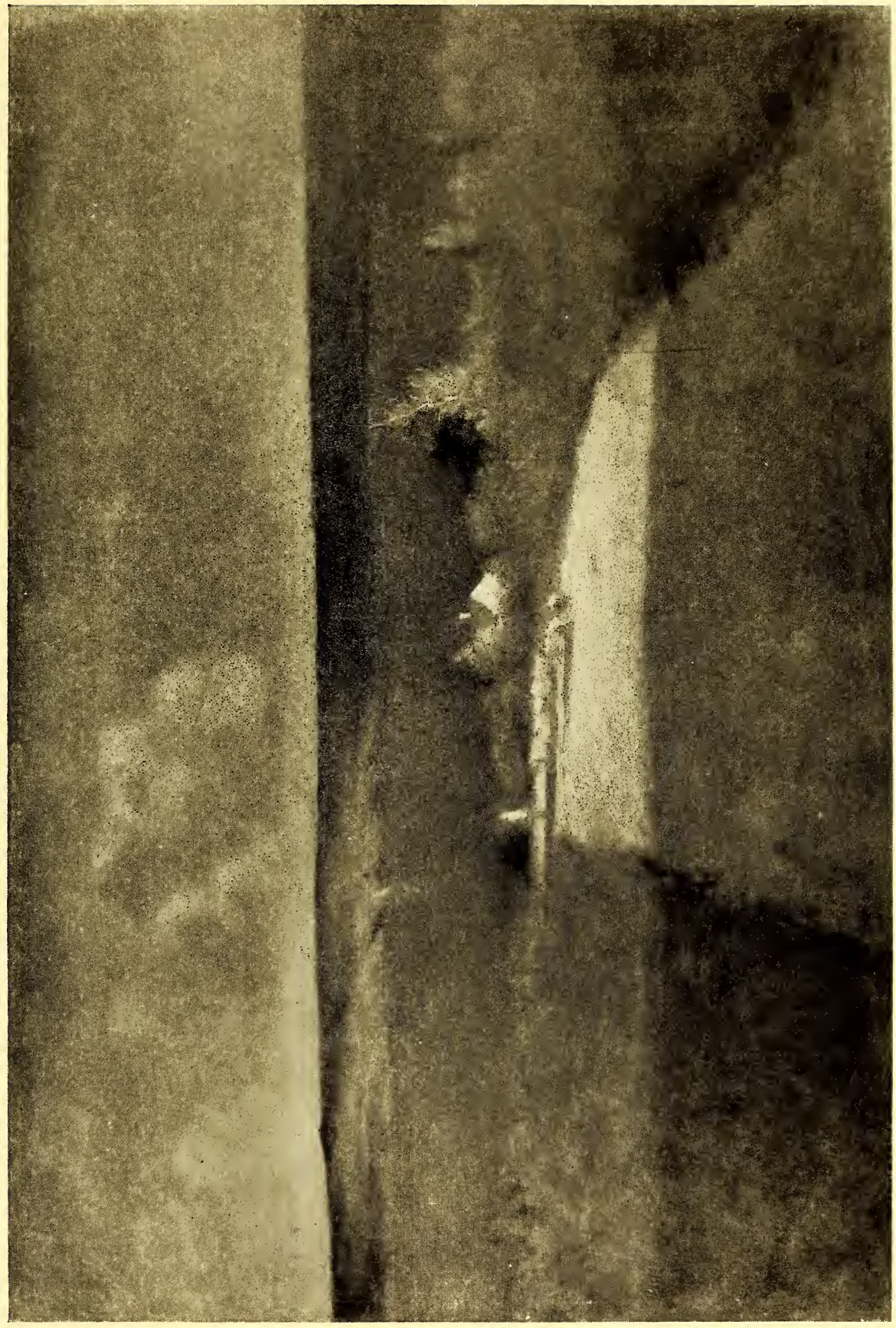


No. 147

\section{HENRY WARD RANGER. N.A. \\ American : 1858-1916}

\section{BECKY COLE'S HILL}

\section{Height, 28 inches; length, 36 inches}

A celebrated Ranger landscape, with the simple motive of a hill-side near East Lyme, Conn. A stone wall runs across the hill near the top, where there are some trees, and in the right foreground is a little pool of water which reflects the blue of the sky. In the sky itself are warm tinted white and gray clouds. Restrained, forceful color and broad general effect make this a notable canvas.

Signed at the lower left, and dated '98.

Purchased from Arthur Tooth \& Sons, New York, 1899. 


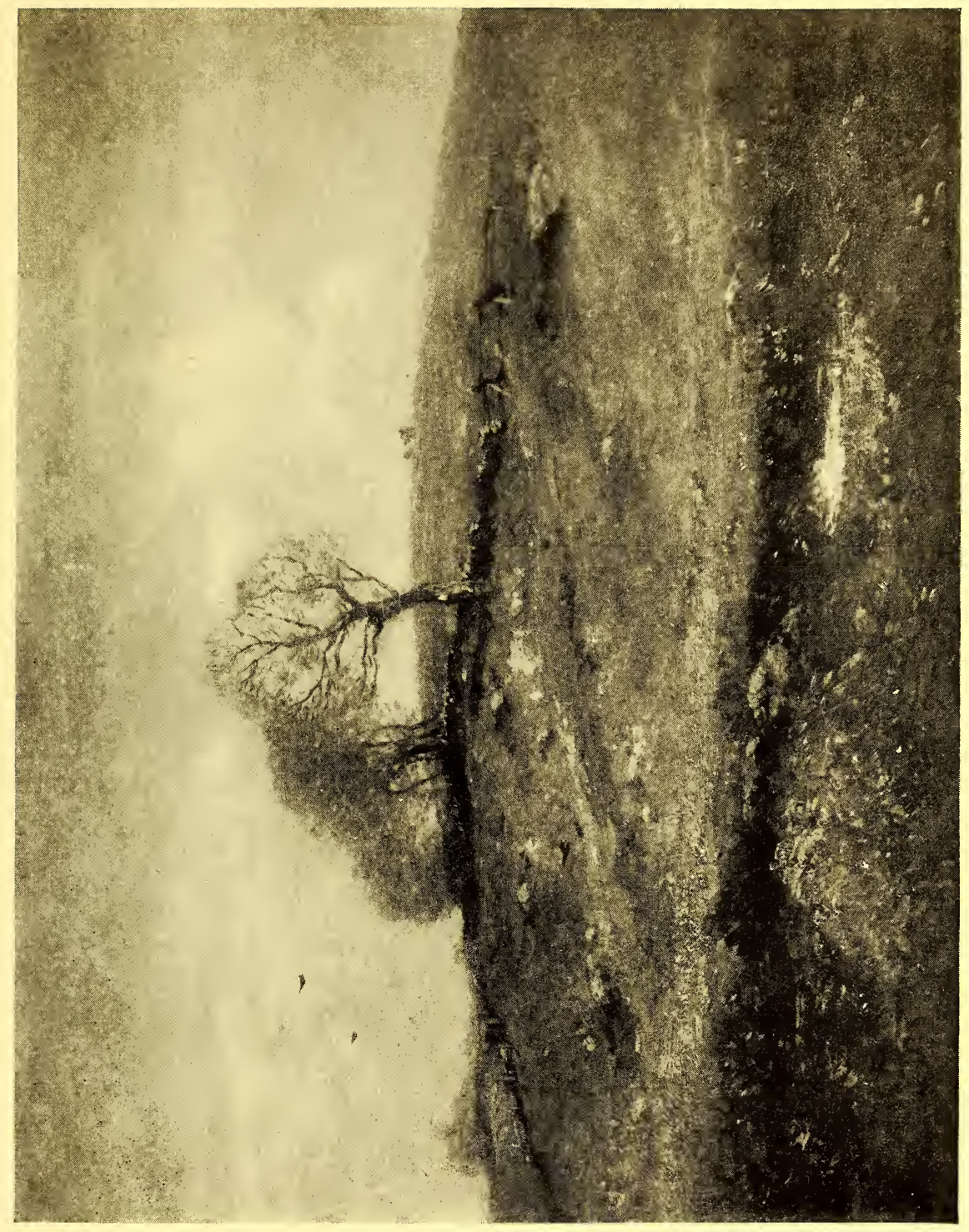


No. 148

\section{ELLIO'T'T DAINGERFIELD, N.A.}

American : 1859 -

\section{THE FOREST OF LATMOS}

\section{Height, 36 inches; width, 30 inches}

Two figures, a shepherd with his crook, seated at the foot of a great tree, which rises from the foreground to the top of the canvas, and a young woman, in white robes, standing before him, form the center of interest in the composition. Nearby are some sheep, lying down. Beyond is a valley filled with mist and, above, a night sky of clouds with spaces of blue where stars are twinkling. The moon is indicated near the middle of the picture.

Signed at the lower left.

Purchased direct from the artist, New York, 1906. 


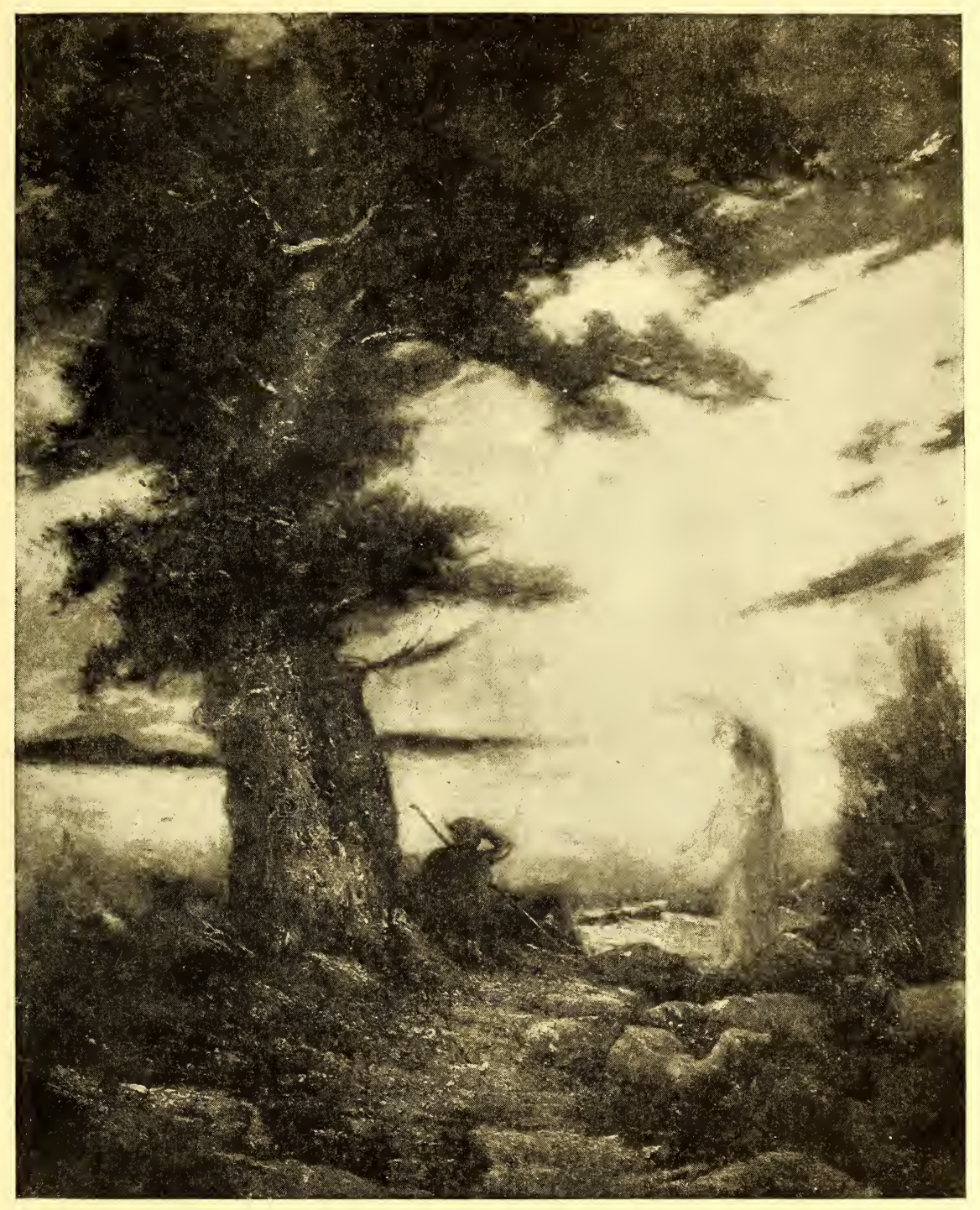




\title{
PAUL DOUGHERTY, N.A.
}

American : 187\%-

\section{BLACK HEAD, MONHEGAN ISLAND}

Height, 26 inches; length, 36 inches

A marine in very sober general tone, showing the sea in the middle portion of the picture, surrounded by high lands on shore, and great rock formations in the foreground. The sky is of dark grays with notes of subdued white, and a gleam of pale sunshine, coming from the right, illumines a part of the shore and glints on the breakers.

Signed at the lower right.

Purchased direct from the artist, New York, 1906.

No. 150

\section{HENRY GOLDEN DEARTH, N.A.}

\author{
American: 1864-
}

THE BROOK

Height, 35 inches; width, 24 inches

'THE composition shows a stream tumbling over a succession of small rocks, from the middle distance to the immediate foreground and on either side are tall beeches, with white and black trunks, the foliage in qualified tints of crimson and yellow. The vista between discloses a group of people indicated by notes of white and red, and, beyond, a timbered valley and a distant range of hills. Overhead is a sky of blue and white. Strong notes of blue in the waters of the brook constitute a foil for the rich coloring of the rest of the landscape.

Signed at the lower right.

Purchased direct from the artist, New York, 1910. 
No, 1.51

\section{HENRY WARD RANGER, N.A.}

Americhn: $1858-1916$

\section{THE LAST OF SPRING}

IIeight, 28 inches; length, 36 inches

A woon interior with stone fences traversing the foreground, a stream in the middle distance and, beyond, seen through the branches of the trees, a hillside. 'The foliage, in the upper part of the picture, shows tints of yellow and orange, while the blue of the sky appears in the open spaces. The warm tone, characterizing the landscape in general, is accented by grays, blacks and whites.

Signed at the lower left, and dated 1909.

Purchased direct from the artist.

No. 152

\section{PAUL DOUGHER'TY, N.A.}

American : $187 \%$

\section{THE' WAVE AND THE CLOUD}

\section{Height, 36 inches; width, 34 inches}

A marine in which surging waters are breaking in white foam in the middle of the picture. Above, a great mass of cloud is depicted, rising in the sky, its upper portion illumined by the sun. The prevailing color notes are qualified blue and green and violet grays, with accents of warm white.

Signed at the lower right.

Purchased direct from the artist, New York, $190 \%$. 
No. 153

\section{HORATIO WALKER, N.A.}

Anerican : 1858

\section{MOONRISE-A CANADIAN PASTORAL}

Height, 28 inches; length, 38 inches

In the center of the picture are a yoke of oxen, one white, the other red, just detached from an old-fashioned plow, and two men about to leave the field after the day's work. In a space of evening blue, in the gray sky, the disk of the moon is seen peeping over a cloud near the horizon.

Signed at the lower right, and dated 1902.

Purchased from N. E. Montross, New York, 1903. 


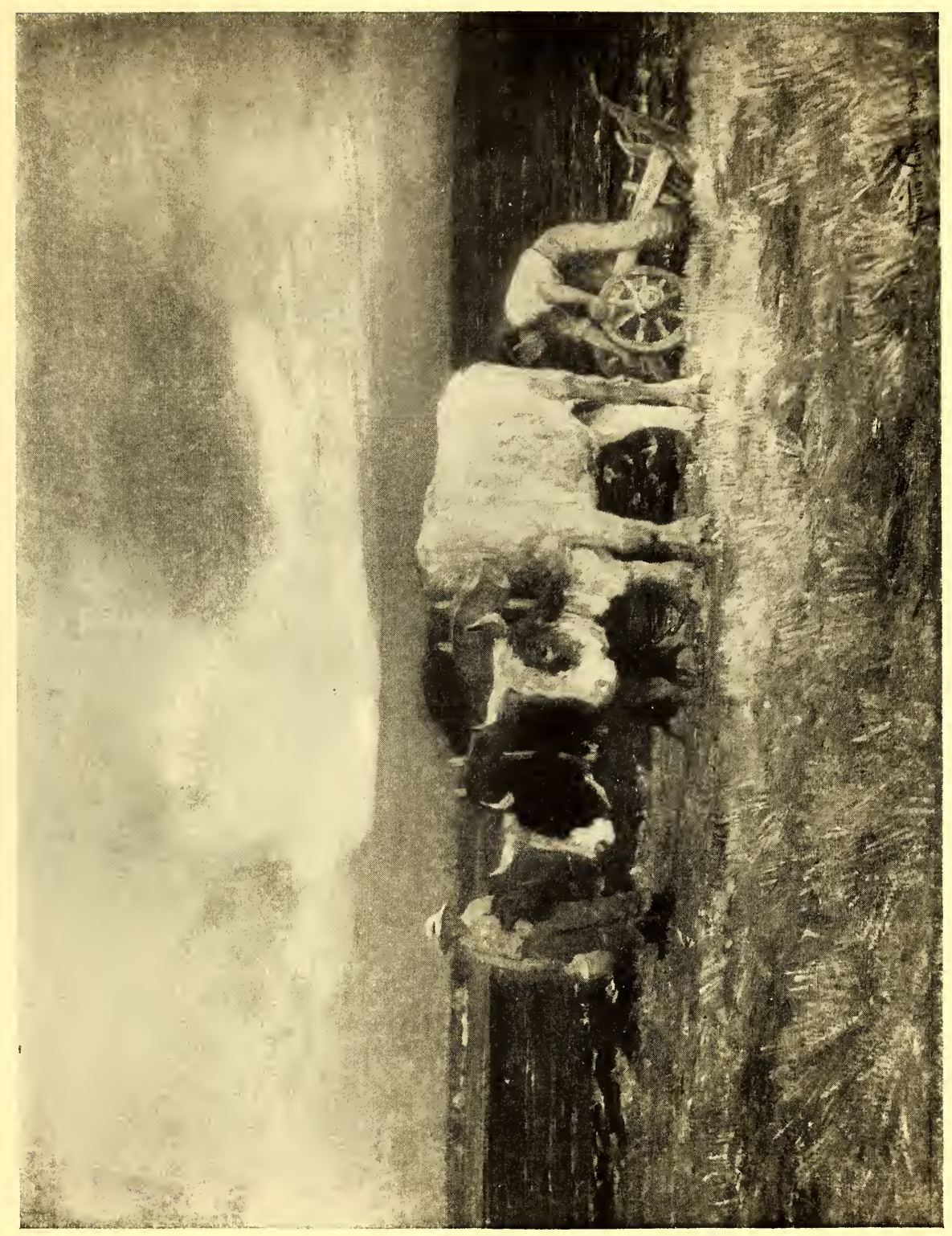


No. 154

\section{HENRY WARD RANGER, N.A.}

American: $1858-1916$

\section{SEN'TINEL, ROCK}

Height, 36 inches; width, 28 inches

Gray rock formations on a rugged piece of land, from which the timber has been cut, fill the lower half of the canvas; in the immediate foreground some piles of cord-wood, and a sapling, which has been left standing, rises from behind the rocks in the center of the picture against a sky of gray clouds. On the left is a distant prospect of a wooded hillside. The predominating color notes are greens and yellows with accents of blackish-gray.

Signed at the lower left, and dated $190 \%$.

Purchased direst from the artist. 


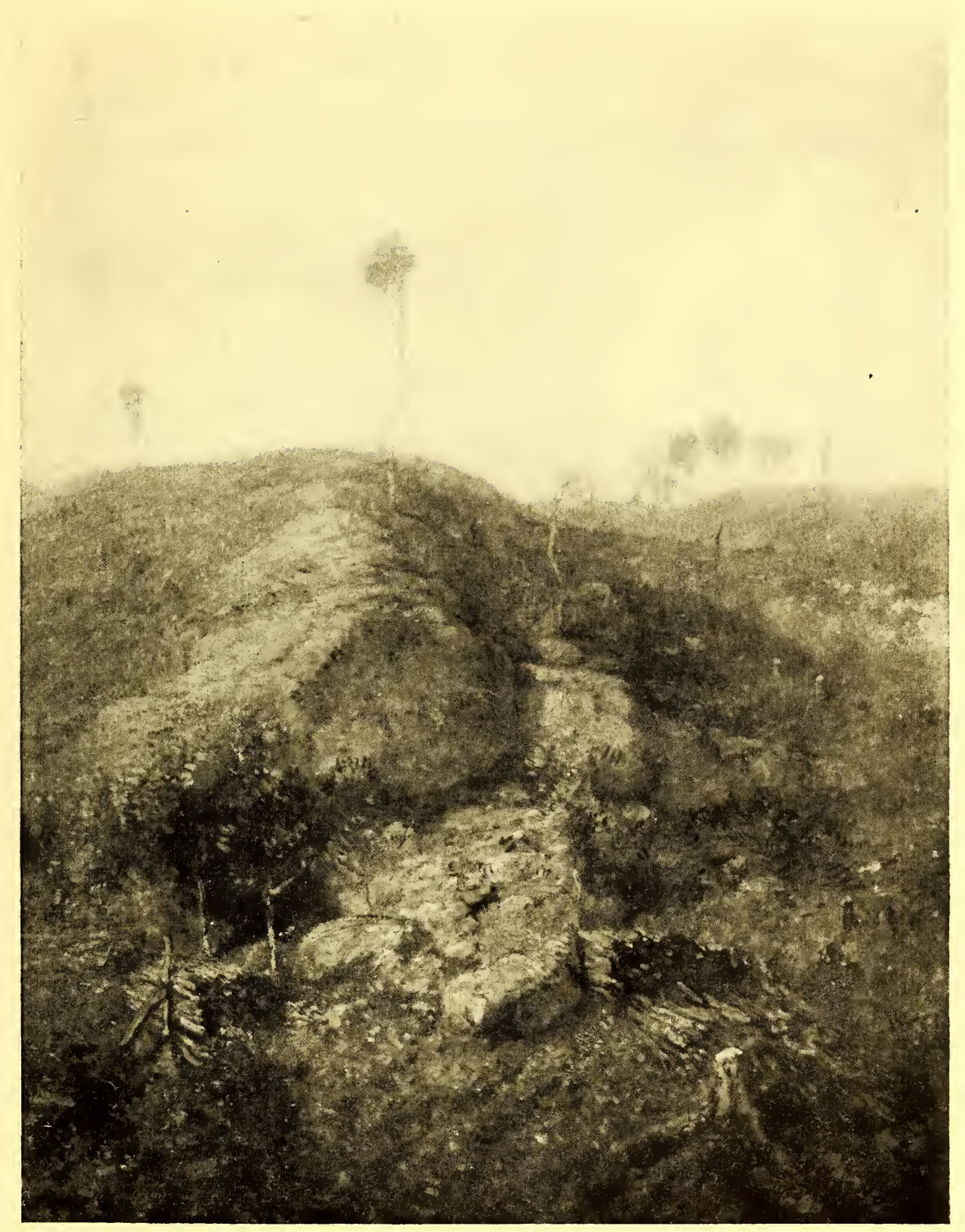


No. 155

\section{WILLIAM GEDNEY BUNCE, N.A.}

American : $1840-1916$

\section{SUNSET-VENICE}

Height, 3r1/2 inches; width, 35 inches

The towers and domes of Venice are depicted in the middle distance of this composition, while the waters in the foreground reflect an evening sky with tints of greenish-yellow and gray in the upper portion, gradating into rose near the horizon where the sun has set. A sail and a buoy on the extreme right give low toned notes of red.

Signed at the lower left. 


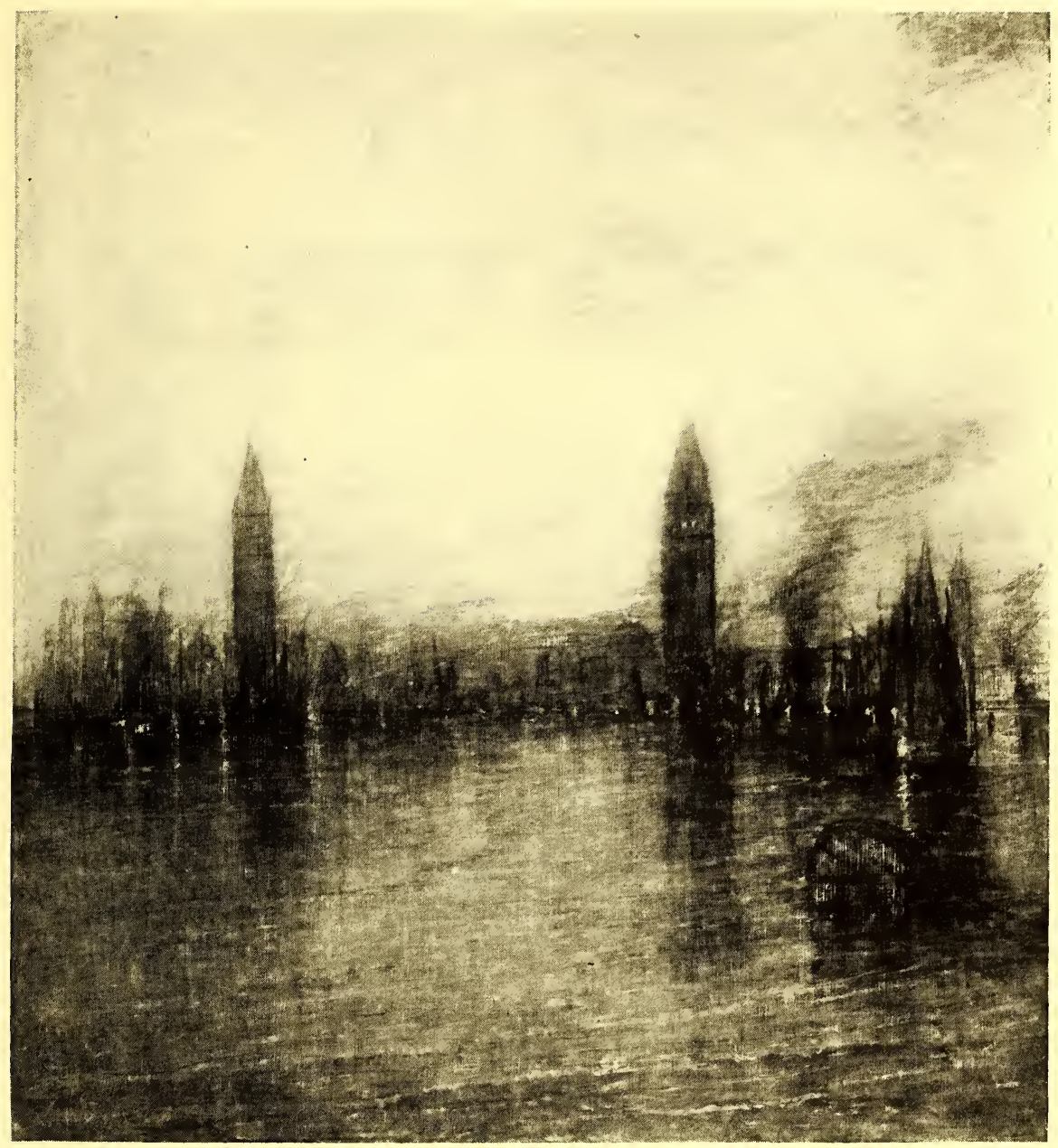


No. 156

\title{
WILIIAM MORRIS HUN'T
}

\author{
American : $1824-1879$
}

\section{SAND-BANK AND WILLOWS, MAGNOLIA, MAS- SACHUSETTS}

Height, 24 inches; length, 42 inches

THE lower part of canvas is occupied by a wide stretch of sand dunes, with willows growing on the crest above. All this is in shadow, while beyond, seen through the open spaces, are a sandy beach, an arm of the sea and a headland bathed in sunlight. The figures of two children, at the extreme right, are in silhouette against this sunny exposure.

No. 76: Originally purchased by Wm. Macbeth at Mrs. S. D. Warren's Sale, January, 1903. Sold to and repurchased from Mr. John Robertson, Moosic, Pa. No. 7\%: Purchased by Macbeth from R. C. Vose, 320 Boylston Street, Boston.

Purchased from the sale of the effects of the artist, Boston, February, 1880, Catalogue No. 43. 


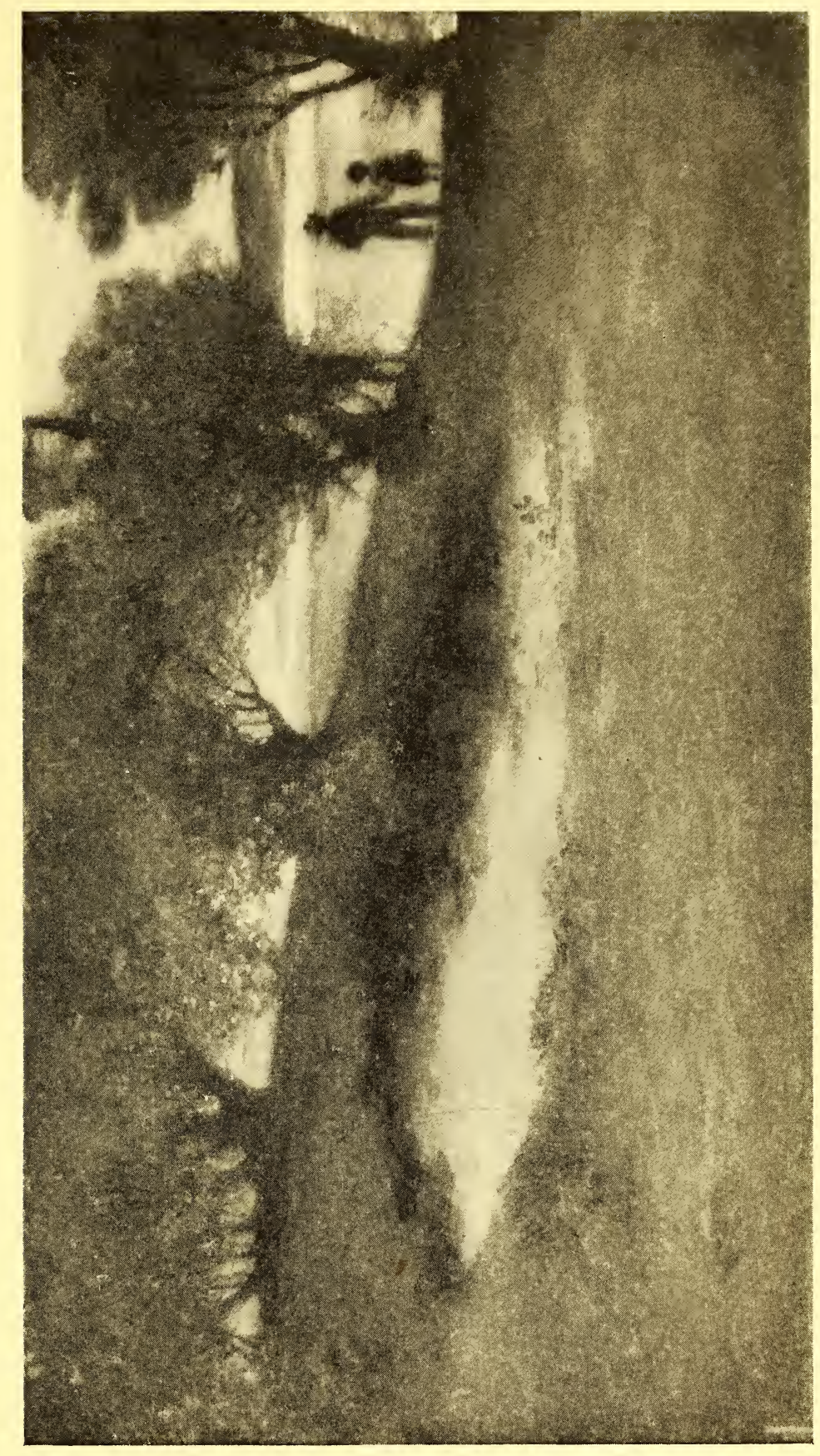


No. 157

\title{
IIOMER D. MAR'TIN, N.A.
}

\author{
Amertcan : $1836-1897$
}

\section{SARANAC IAKE}

Ilcight, 241\% inches; length, 40 inches

'THe foreground depicts the shore of the lake, with a roadway bordering the water and forest trees on a hill-side at the left. The surface of the lake occupies the middle portion of the picture; on the right and beyond are mountains with three peaks outlined against the gray sky, in which are some small spaces of blue.

Signed at the lower left, and dated $18 \% 8$.

Purchased from William Macbeth, New York, March 30, 1899. Certificate from William Macbeth states this painting was painted to order in 1878 for the late Dr. Mosher of Albany, N. Y., an intimate friend of Homer Martin. Purchased from Dr. Mosher's family by Mr. James Vint of Albany, one-time quarantine officer of Nere York, and from the latter purchased by Mr. Macbeth. Accompanied by a letter from Mrs. Martin, zeidow of the artist, dated March 31, 1899, certifying the authenticity of the painting. 


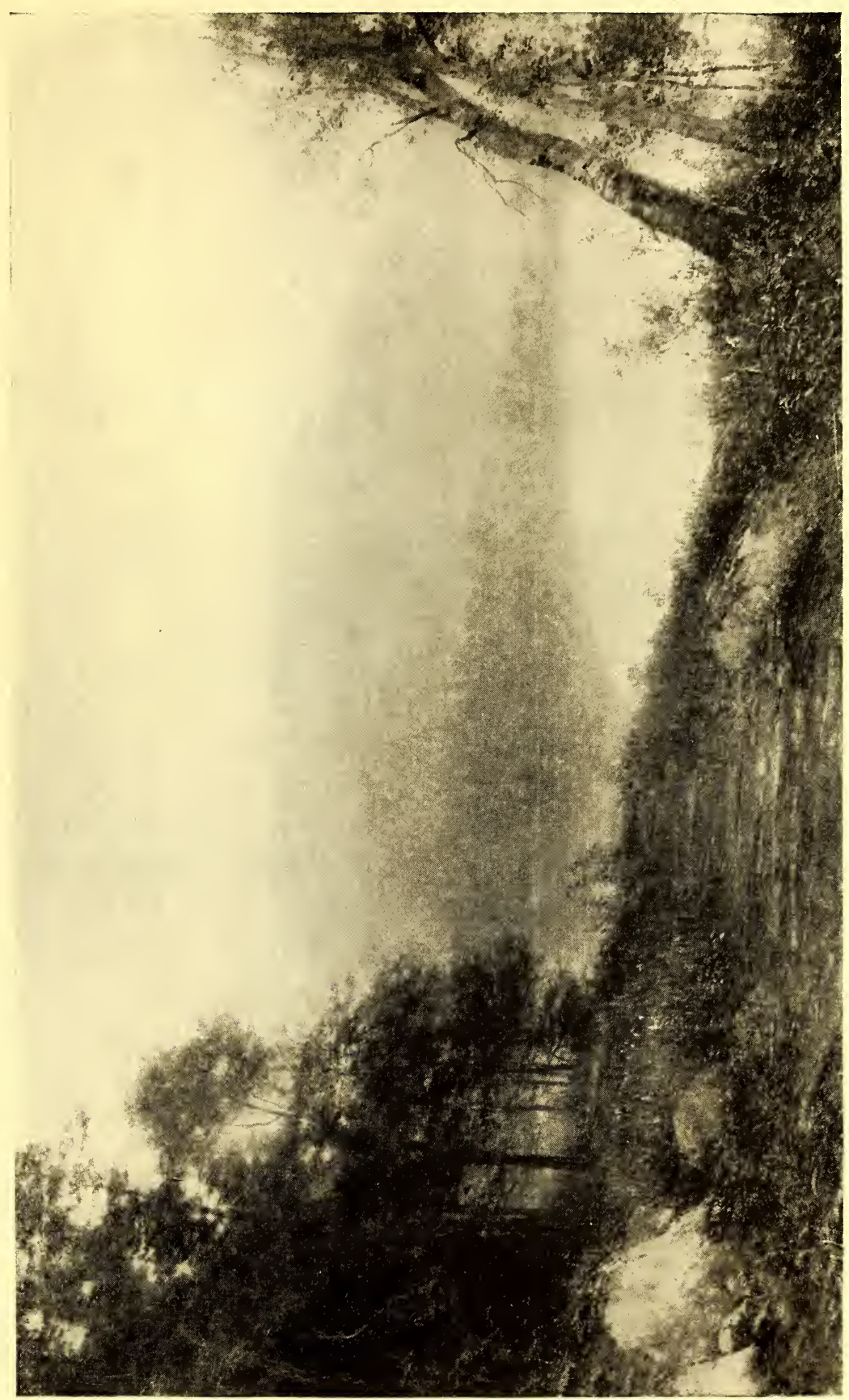


No. 158

\section{HENRY GOLDEN DEAR'TH, N.A.}

Anerican: 1864-

\section{BRIT'TANY CHURCH}

\section{Height, 32 inches; length, 45\%/4 inches}

'THe green sward of the churchyard, bordered by stone walls, occupies the foreground and the church itself, with two or three houses close by, raises its graceful shape in the right center of the composition. The effect is of early evening, the upper part of the church and its spires being illumined with a pinkish glow from the sinking sun. 'The sky of pale blue with white clouds and the moon, rising at the extreme right, complete the picture.

Signed at the lower right.

Purchased direct from the artist, New York, 1910. 


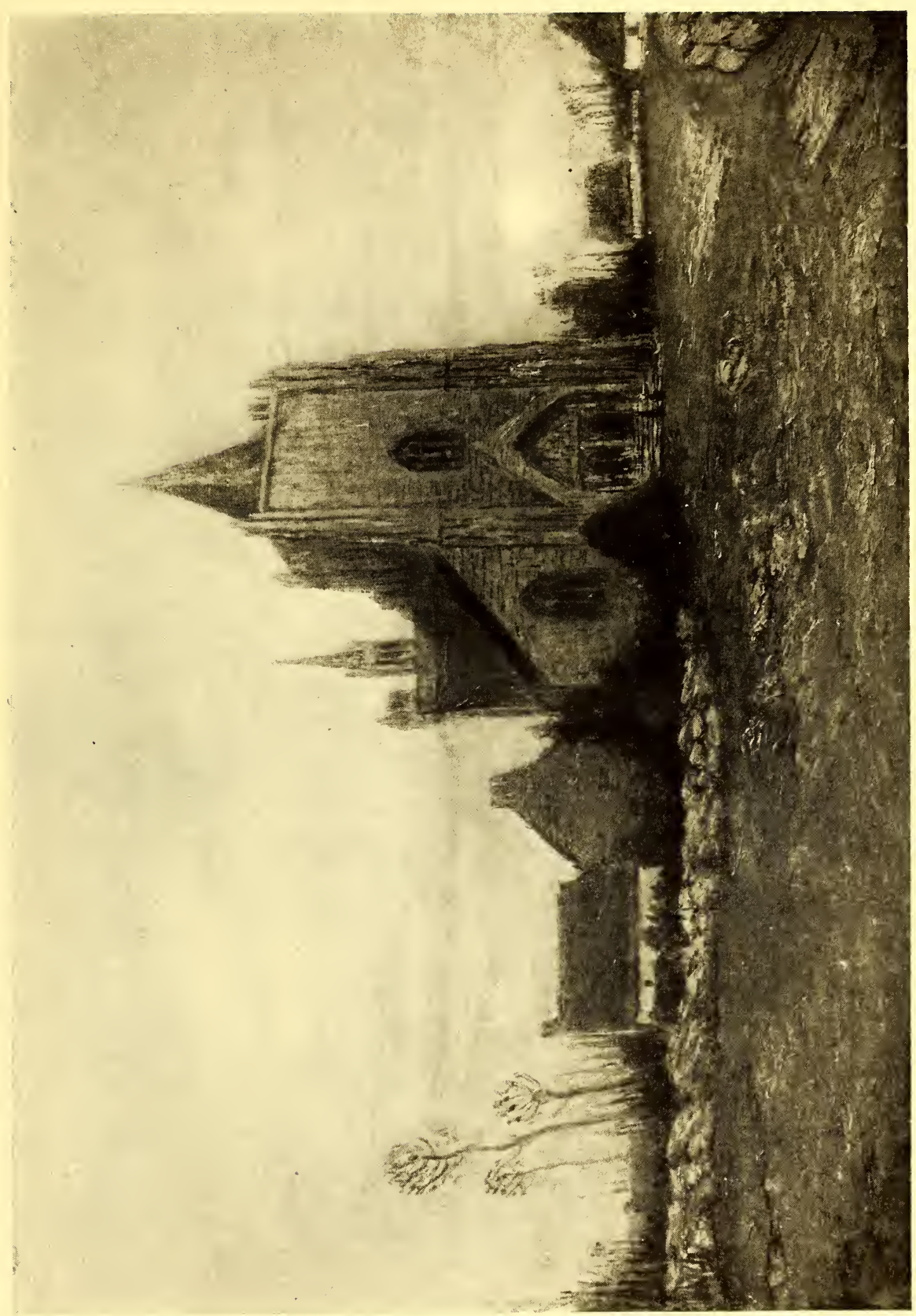


No. 159

\section{GEORGE FULLER, A.N.A.}

American : 1822-1884

\section{GIRL AND TURKEYS}

Height, 30 inches; length, 50 inches

Is a foreground of meadows with a border of woods on the left and a hut, near the middle of the picture, is the figure of a girl whose arms are extended in a gesture of gently driving a flock of turkeys. Above is a sky of gray clouds. This wellknown work exhibits the characteristic handling of the celebrated American artist as well as his distinctive qualities of color.

Signed at the lower left. On back: "Copyright, 1884, by the Estate of the late George Fuller, Boston."

Purchased from William Macbeth, New York, April 2, 1904, who purchased the painting from Williams \& Everett, Boston, as agents of the owner, a Mr. Jewett of Brooline, Mass.

Illustrated in the Memorial Volume of Mr. Fuller's work, and listed as being painted in 1884, the year the artist died. 


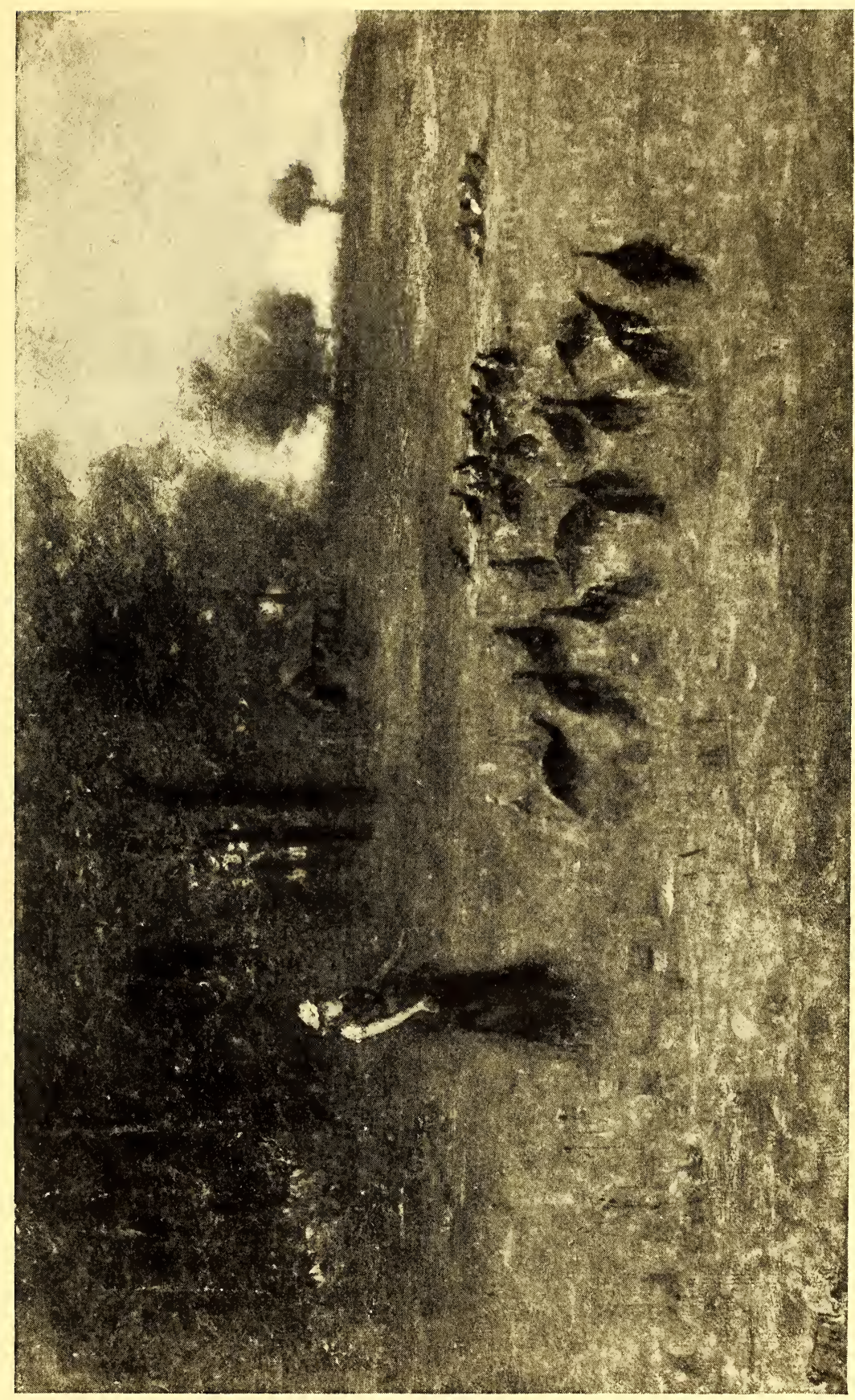


No. 160

\section{PAUL DOUGHERTY, N.A.}

American: $18 \% 7$ -

\section{AN AISLE OF THE SEA}

Height, 36 inches; length, 48 inches

Great masses of jagged rocks, standing up on the right and left of this composition, form a sort of passage-way through which the waters of the ocean are seen rushing tumultuously, while spray is thrown up against the rocks and the surf boils, in the foreground. Sunlight falls from the left, emphasizing the color in the central portion of the picture, and the heavy shadows of the foreground contain reflected light as well as a glint of sunshine.

Signed at the lower left, and dated 1910.

Purchased direct from the artist, New York, 1912. 


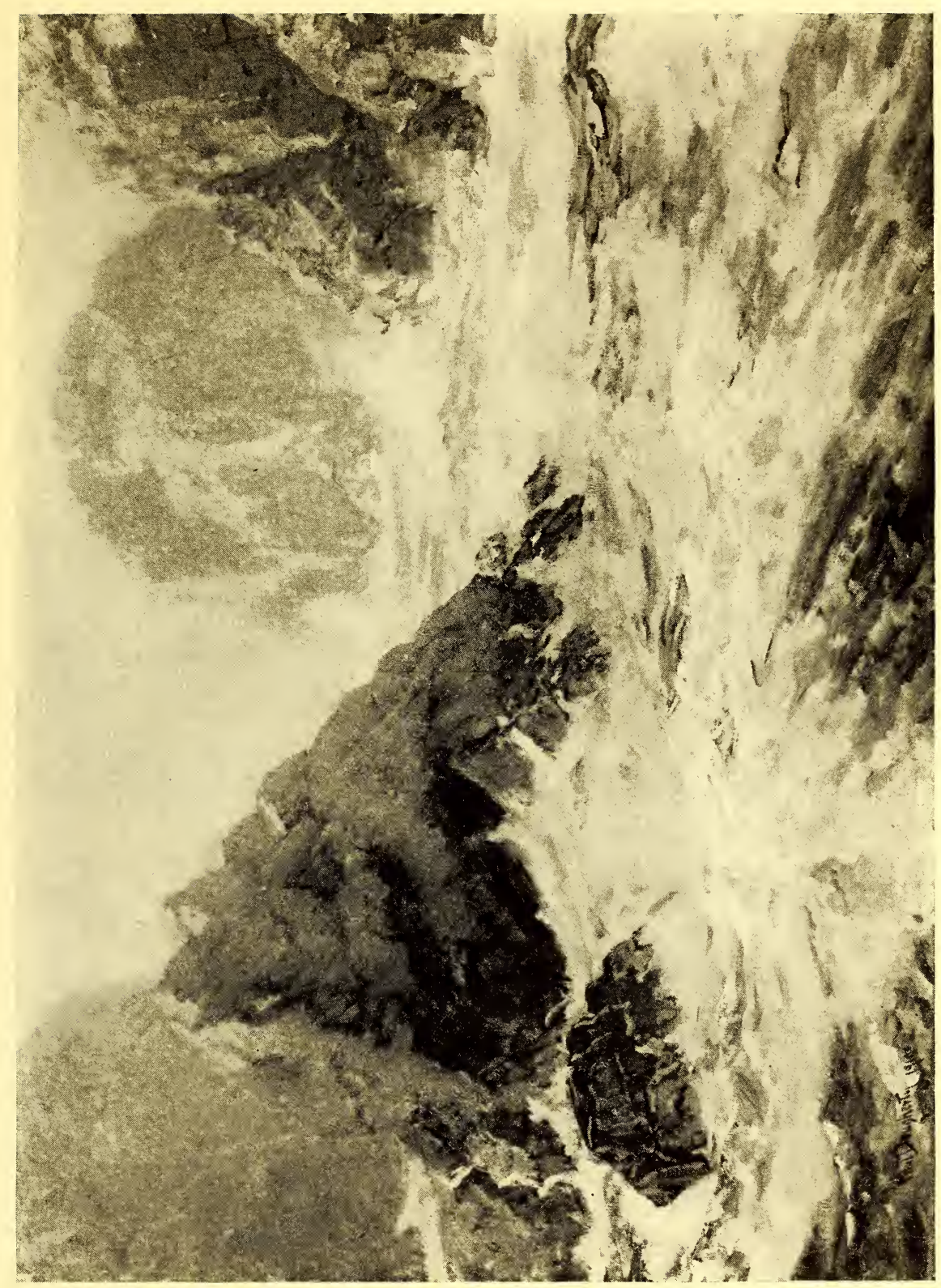




\section{ARTHUR B. DAVIES}

Anerican : 1862-

\section{A LAKE IN THE SIERRAS}

\section{Height, 18 inches; length, 40 inches}

The lake, which gives the picture its title, is seen lying deep down amid the mountain slopes, the view of it obscured considerably by the trunks of giant trees which rise from the foreground and by masses of foliage. These frame in, in the middle of the composition, a view of the mountain ranges with distant, lofty peaks and a sky with clouds illumined by a sinking sun.

Signed at the lower left.

Purchased from William Macbeth, New York, $190 \%$.

No. 162

\section{HENRY WARD RANGER, N.A.}

Anerican : $1858-1916$

\section{SEPTEMBER GALE: NOANK HARBOR}

Height, 28 inches; length, 36 inches

Is the foreground at the right and on a headland jutting out in the sea are the buildings of the town; in the waters near the shore are anchored, or tied, a number of small sailboats. The waters extend beyond to the horizon and above is a stormy sky with black, lowering clouds in the upper portion. Some color notes of red and accents of white in the buildings relieve the sombre general tone of the picture.

Signed at the lower left, and dated 1904.

Purchased direct from the artist, New York, 1905. 
No. 163

\title{
HENRY GOLDEN DEARTH, N.A.
}

American: 1864-

\section{LOVE AMONG THE RUINS}

\author{
Height, 35 inches; length, 46 inches
}

'The composition shows in the middle portion pièces d'eau, one above the other, and on either side groups of men and women in brilliant costumes seated on the grass, or gathered about a temple, which appears on the right amid tall trees in rich red autumn foliage. On the left are two or three other trees, and in the vista beyond appear the forms of hills and belts of forest -all similarly tinged with the reddish glow. Above is an evening sky of warm yellow blue, broken with masses of pink gray clouds.

Signed at the lower right.

Purchased direct from the artist, New York, $190 \%$.

No. 164

\section{ELLIO'T'T DAINGERFIELD, N.A.}

\author{
American: 1859-
}

\section{MOUNTAIN SHOWERS}

Height, 30 inches; length, 45 inches

The lower part of the picture is occupied by a great hillock, over the brow of which, on the left, appears a range of mountains. Hanging over the valley is a horizontal cloud with rain descending from it into the valley below. The sky toward the right of the picture shows broken clouds with a space of blue.

Signed at the lower right, and dated 1906.

Purchased direct from the artist, New York, $190 \%$. 
No. 165

\section{JULIAN RIX}

American : $1851-1903$

\section{SUNNY AFTERNOON, POMPTON VALLEY}

\section{Height, 30 inches; length, 40 inches}

Lever meadows and pasture lands, with a small stream in the left foreground; on the right, a fine oak in brown autumn foliage and other trees beyond. Above the low horizon is a high sky of blue with masses of clouds tinged by the sunlight. Part of the foreground is in shadow, and other shadows are so placed in the picture as to make effective the masses of foliage of the oak tree shining in the sun.

Signed at the lower right, and dated 1899.

Purchased direct from the artist, New York, 1899. 


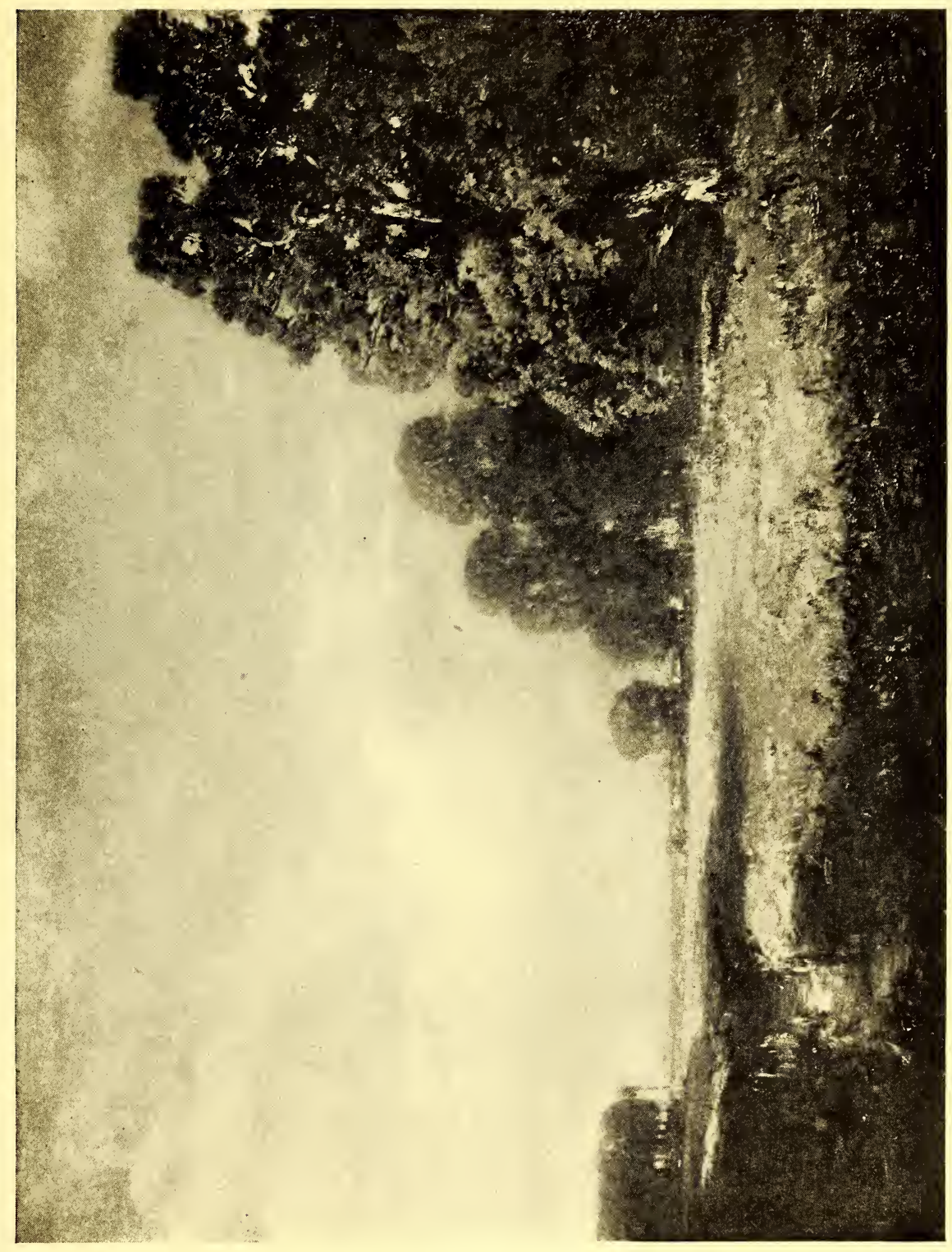




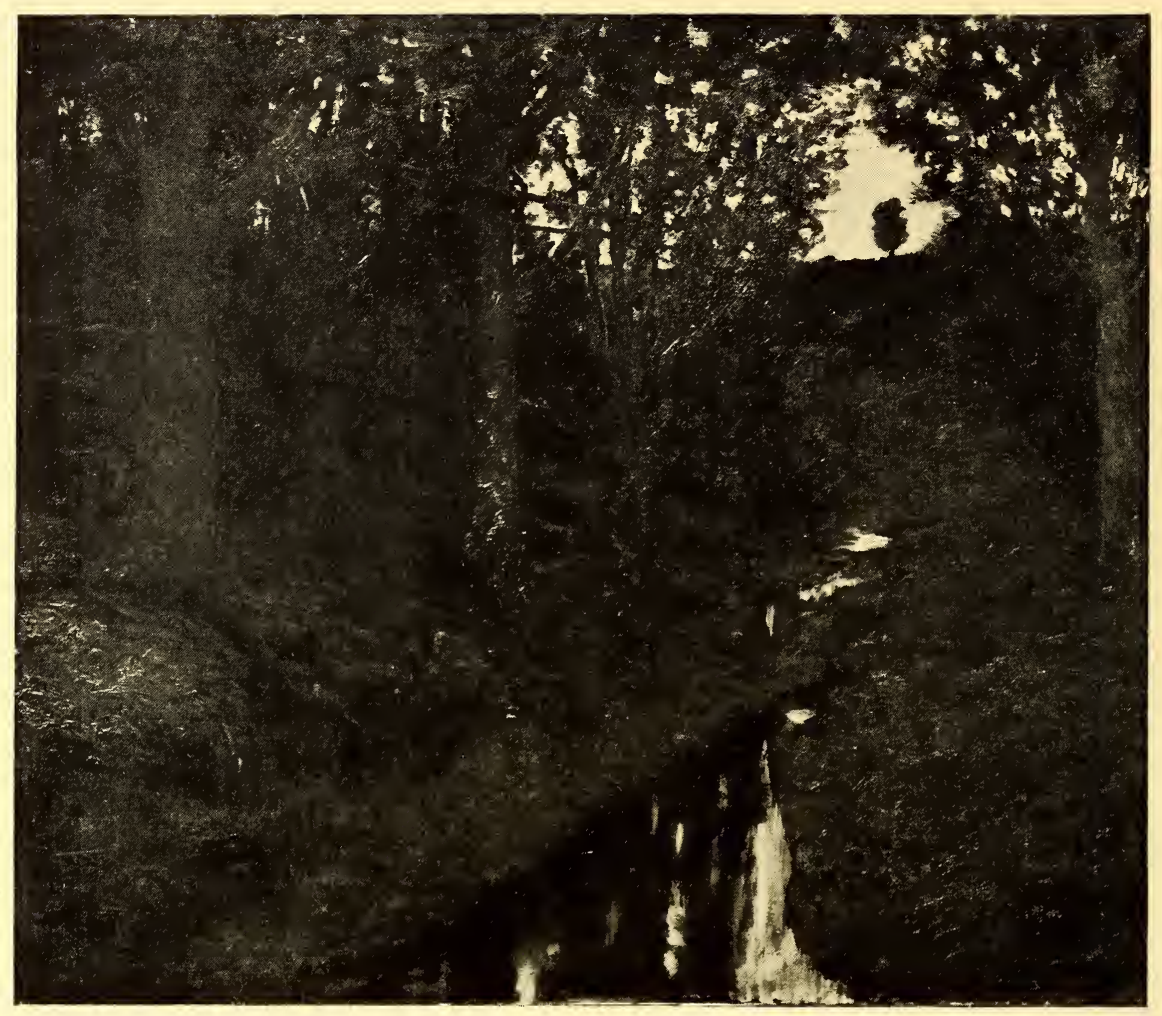

No. 166

\section{BEN FOSTER, N.A.}

American : 1852 -

A MEMORY

Height, 36 inches; length, 42 inches

Through a ravine in the foreground runs a stream with quiet waters; at the left a forest on a hill-side. In the upper part of the picture an evening sky is seen through the foliage, and its rosy tints are reflected in the water.

Signed at the lower left.

Purchased direct from the artist, New York, 1902. 
LIST OF ARTISTS REPRESENTED

AND THEIR WORKS 



\section{LIST OF ARTISTS REPRESENTED AND THEIR WORKS}

BEAL, Reynolds, N.A.

CATALOGUE NUMBER

Off New London

BLAKEloCK, Ralph Albert, N.A.

Summer-Catskills

Indian Hunter

The Wayfarers

Early Evening

BRUSH, George De Forest, N.A.

Boy with a Green Cap

Girl's Head

BUCKLIN, W. S.

Early Spring Morning

BUNCE, William Gemney, N.A.

Venice-Moonlight

Sunset-Venice

CHAPMAN, Carlton 'T., N.A.

The Lighthouse

CHASE, William Merritt, N.A.

Near Bay Ridge

CHURCH, Frederick S., N.A.

Spring Song

A Surf Phantom 
COLMAN, Samuel, N.A.

COMAN, Charlotte Buell, A.N.A.

In the Fall of the Year

CRANE, Bruce, N.A.

Evening

CURRAN, Charles Courtney, N.A.

Girl with Violin

DAINGERFIELD, Elliott, N.A.

The Drama of the Mountain Tops 60

Sunset-Mists and Shadows 77

Dead Trees $\quad 79$

The Forest of Latmos 148

Mountain Showers 164

DAVIES, Arthur B.

A Lake in the Sierras 161

DaVis, Charles Harold, N.A.

Sunset on the Moor 16

Summer Clouds 43

The Awakening of Spring 140

DEARTH, Henry Golden, N.A.

Passing of the Wave 10

Gray Weather 19

Brittany Coast 32

Anemone Pool 42

Through the Beeches $\quad 68$

The Emerald Pool 101 
DEARTH, Henry Golden-Continued

The 'Three-master'

A Gray Day, Boulogne-sur-Mer

Love among the Ruins

The Brook

A Brittany Church

DESSAR, Louis PAUL, N.A.

Nocturne-Moonrise with Sheep

The Return-Evening

Moonlight

Hauling the Winter's Wood

Changing Pasture-October

DOUGHerTY, PAUl, N.A.

The Incoming Tide

Easterly Storm-Boar's Head

Mid-Island Gorge

Cornwall Rocks

Evening after the Rain

Gold and Gloom

134

Black Head, Monhegan Island

149

The Wave and the Cloud

152

An Aisle of the Sea

EAKINS, 'Thomas, N.A.

Professionals at Rehearsal

FOO'TE, WILl Howe, A.N.A.

The Old Bridge

FOSTER, BeN, N.A.

A Murky Evening

A Memory 
FULLER, George, A.N.A.

Shearing the Donkey

Ideal Head

Girl and Turkeys

GIFFORD, R. Swain, N.A.

Solitude

HASSAM, Childe, N.A.

Messenger Boy

Across the Park

On the Avenue in Winter

HAW'THORNE, Charles Webster, N.A.

Along the River

The Grand Canal-Venice

HiTCHCOCK, George, A.N.A.

Windmill and Geese

The Dunes, Holland

HOMER, WinsLOW, N.A.

A Wreck near Gloucester 102

Perils of the Sea 115

Sailing Out of Gloucester Harbor 117

The Turkey Buzzard $\quad 129$

A Voice from the Cliffs 133

HOWE, William Henry, N.A.

On the Marshes-Holland 35

Young Vagabonds $\quad 52$

HUN'T, William Morris

Head of a Spanish Girl 25

Old Mexico 47

Sand-bank and Willows, Magnolia, Massachusetts 156 
INNESS, George, N.A.

Leeds, New York $\quad 90$

Near Montclair $\quad 128$

Returning from Pasture-Milton 135

One the Sainte-Croix River, Canada $\quad 146$

INNESS, George, Jr., N.A.

In the Cool of the Evening : 44

JONES, Hugh Bolton, N.A.

Near Orange, New Jersey

KOST, Frederick W., N.A.

The Driftwood Gatherer $\quad 63$

LA FARGE, Johs, N.A.

Bridle Path-Tahiti 116

LOEB, Louis, N.A.

Byblis

MAR'TIN, Homer D., N.A.

Low Tide-Honfleur $\quad 20$

Lighthouse-Honfleur $\quad 86$

Ruby Strong-Normandy $\quad 95$

Moonlit Pond-Honfleur $\quad 96$

The Dunes 100

Indian Summer $10 \gamma^{2}$

Autumn on the Susquehanna 123

Saranac Lake 157

MINOR, Robert C., N.A.

Early Autumn 108 
MORAN, Thomas, N.A.

A Venetian Fiesta $\quad \mathbf{5 0}$

The Mountain of Loadstone (Arabian Nights) 57

In the Teton Range-Idaho 64

MOSLER, HeNry

Good-Night

MURPHY, J. Francis, N.A.

Early Autumn $\quad 8$

The Woods $\quad 87$

Sunset $\quad 88$

The River $\quad 91$

October Afternoon $\quad 98$

Changing Maples 104

Springtime in the Catskills 112

Approach to the Old Farm 119

Afterglow-October 137

OCH'TMAN, Leonard, N.A.

$\begin{array}{ll}\text { Autumn Twilight } & 80\end{array}$

PARRISH, STEPHEN

Market-Place, Yvetôt, Normandy 3

PARTON, Arthur, N.A.

The Passing Shower 61

PAUII, Richard

A Gray Day $\quad 22$

PE'Ters, Charles Rollo

San Juan Mission $\quad 78$

POTTHAST, EDward H., N.A.

Off the Grand Banks $\quad 58$

The Village Carpenter $\quad 62$ 
RANGER, Henry Ward, N.A.

Spring-East Lyme

Valley of the Somme

Cloud and Sea-Porto Rico

Peaceful Moonlight Reigns

69

A Classic-Mason's 1sland

Golden Evening: Noank Harbor 130

Clearing Fires 138

Cloud and Sunshine: Near an Old Quarry, New England

Becky Cole's Hill

The Last of Spring

Sentinel Rock

September Gale: Noank Harbor

162

REHN, Frank Knox Mor'ton, N.A.

In Mid-Ocean

Marine

RIX, JULIAN

'The Quarry

Singac Meadows

Edge of the Wood

Northern Lake, New Brunswick, Canada

Sumny Afternoon, Pompton Valley

ROBINSON, 'THEODORE

'The 'Thatched Cottage

'Twachtman's House

Gathering Plums

RYDER, Alber't Pinkham, N.A.

'Twilight 
SAR'TAIN, William, A.N.A.

Italienne $\quad \mathbf{2 4}$

Arab Camp-Outside the Walls 37

The Cloud 46

An Arab School in Algiers 56

SCHOFIELD, Wal'ier Elmer, N.A.

A Breezy Day, Early Autumn 73

SMILLIE, George Henry, N.A.

At East Gloucester $\quad 30$

SNELI, Henry BAyley, N.A.

'Iwilight at Sea

'IRYON, Dwigh'T William, N.A.

Moonrise-October $\quad 94$

Across the Fields-November $\quad \mathbf{1 2 6}$

'IWACH'TMAN, JoHN HENkY

'The Frozen Brook

132

Rapids in the Yellowstone 142

WALKER, Hora'tio, N.A.

'The End of the Day 12

Girl Feeding 'Turkeys 143

Moonrise-A Canadian Pastoral 153

WHI'T'IREDGE, Wor'hington, N.A.

A Village by the Sea

WIGGINS, Carleton, N.A.

'The Storm 
WILliams, Frederick Ballatid, N.A.

'The Quiet Hour

Valley of the Passaic 28

Halcyon Days 110

WYAN'T, Alexander H., N.A.

A Gray Day

Killarney

County Kerry, Ireland

Evening-Early Autumn

The Old Sand Road

106

A Brook in the Catskills

109

Nightfall

124

The Dawn

1336

Keene Valley

144 



\section{FOR INHERITANCE TAX}

AND OTHER PUR POSES

\section{The American Art Association}

IS EXCEPTIONALLY WELL EQUIPPED

TO FURNISH

INTELLIGENT APPRAISEMENTS

$\mathrm{OF}$

ART AND LITERARY PROPERTY

JEWELS AND PERSONAL EFFECTS OF EVERY DESCRIPTION

IN CASES WHERE

PUBLIC SALES ARE EFFECTED

A NOMINAL CHARG ONLY WILL BE MADE

THE AMERICAN ART ASSOCIATION

MADISON SQUARE SOUTH

NEW YORK

TELEPHONE, 3346 GRAMERCY 
COMPOSITION, PRESSWORK AND BINDING BY

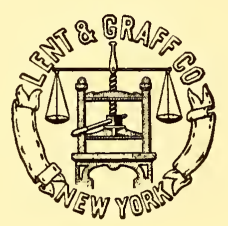





<smiles>CC</smiles> 
